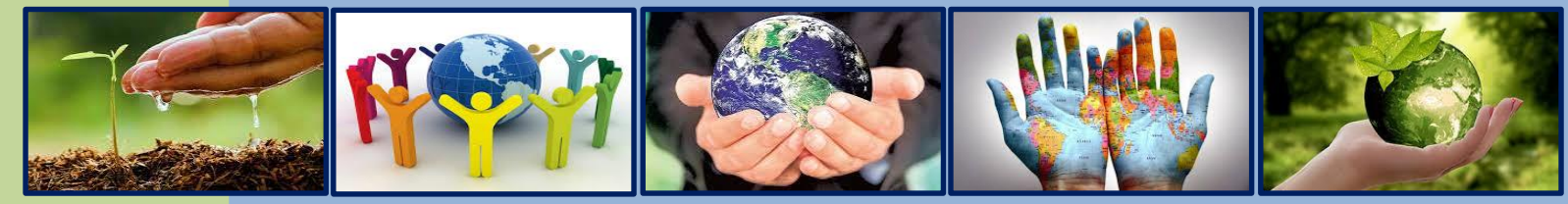

ISSN: 2298-0946, E-ISSN: 1987-6114; DOI PREFIX:10.36962/CESAJSC

JULY 2021 VOLUME 43 ISSUE 04

(c) SC SCIENTIFIC JOURNALS

\title{
THE CAUCASUS
}

ECONOMIC \& SOCIAL ANALYSIS JOURNAL OF SOUTHERN CAUCASUS

MULTIDISCIPLINARY JOURNAL

REFEREED \& REVIEWED JOURNAL

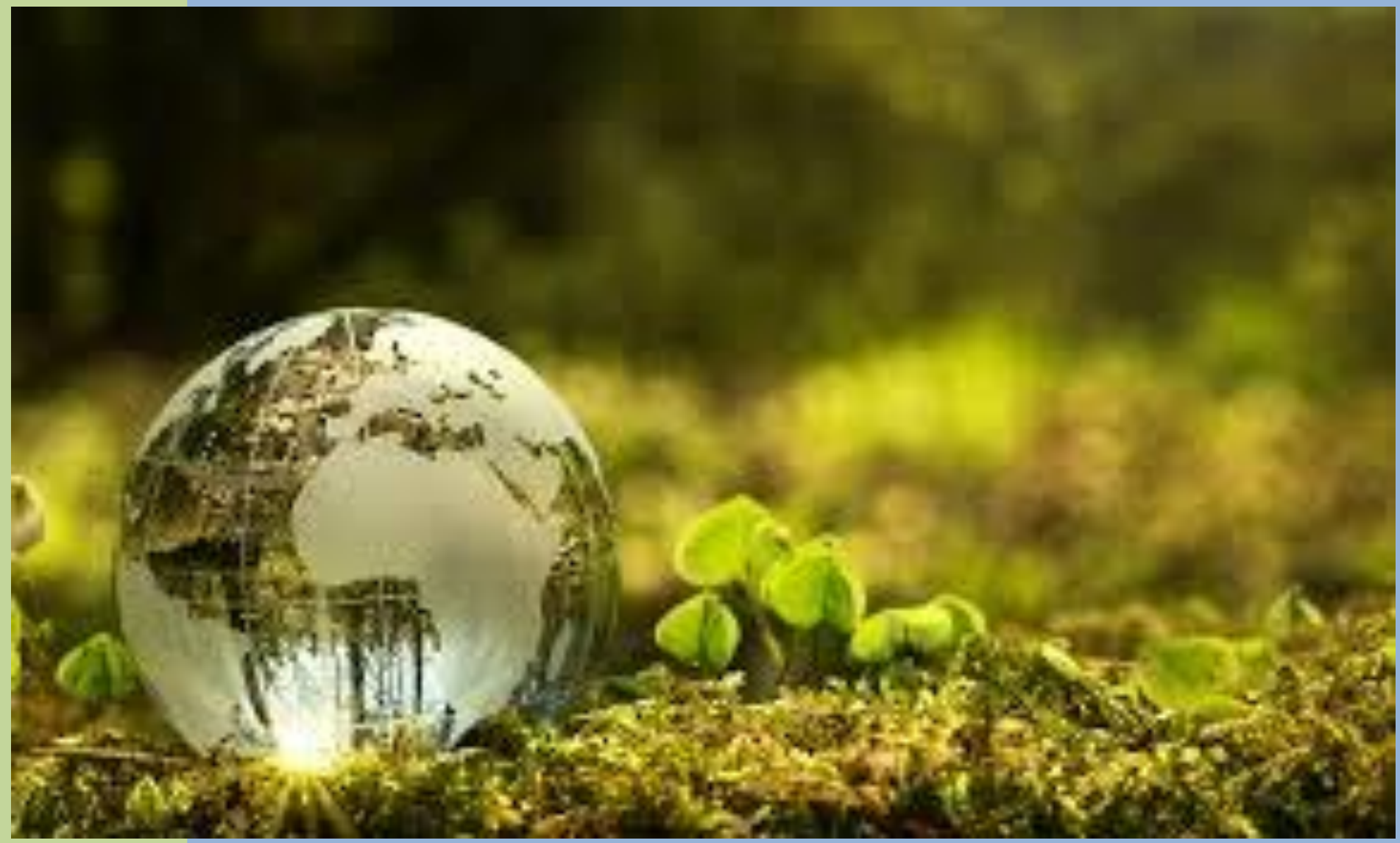

AGRICULTURAL, ENVIRONMENTAL \& NATURAL SCIENCES

SOCIAL, PEDAGOGY SCIENCES \& HUMANITIES

MEDICINE AND BIOLOGY SCIENCES

REGIONAL DEVELOPMENT AND INFRASTRUCTURE

ECONOMIC, MANAGEMENT \& MARKETING SCIENCES

LEGAL, LEGISLATION AND POLITICAL SCIENCES

Platform \&. workflow by

http://www.scia.education/ 
The beautiful thing about learning is nobody can take it away from you-B. B. King

ISSN: 2298-0946, E-ISSN: 1987-6114; DOI PREFIX:10.36962/CESAJSC

JULY 2021 VOLUME 43 ISSUE 04

(C) SC SCIENTIFIC JOURNALS

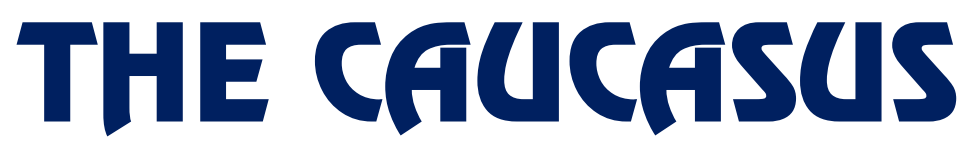

ECONOMIC \& SOCIAL ANALYSIS JOURNAL OF SOUTHERN CAUCASUS

MULTIDISCIPLINARY JOURNAL

REFEREED \& REVIEWED JOURNAL

JOURNAL INDEXING

IMPACT FACTOR OF RUSSIA ISC 2017-0.028

GEORGIA, TBILISI 2021 


\section{Editors-in-chief:}

Historical and Natural Sciences

Lienara Adzhyieva

Tubukhanum Gasimzadeh

Social, Pedagogy Sciences \& Humanities

Eka Avaliani

Medicine, Veterinary Medicine, Pharmacy and Biology Sciences

Mariam Kharaishvili

Technical, Engineering \& Applied Sciences

Nikolay Kurguzov

Regional Development and Infrastructure

Lia Eliava

Economic, Management \& Marketing Sciences

Badri Gechbaia

EDITORIAL BOARD LIST SEE PAGE 52

ISSN: 1987-6521; E-ISSN:2346-7541; DOI prefix: 10.36962/CESAJSC

(P) Publisher: Representation of Azerbaijan International Diaspora Center in Georgia. SCS Journals CEditorial office: 0165 Georgia. Marneuli municipality. Village Takalo.

()Typography: Representation of Azerbaijan International Diaspora Center in Georgia. SCS Journals. Registered address: 0165 Georgia. Marneuli municipality. Village Takalo.

Telephones: +994552 4170 12; +994518 648894 .

Website: https://scia.website/

E-mail: sc.mediagroup2017@gmail.com

๑) Publisher: LTD The Southern Caucasus International Academy of Modern Sciences. (UK, London).

Director and shareholder: Namig Isazade. Professor. PhD in Business Administration.

(c) Editorial office: 71-75 Shelton Street, Covent Garden, London, WC2H 9JQ, UK.

OTypography: LTD International Research, Education \& Training Center. (UK, London).

Registered address: 71-75 Shelton Street, Covent Garden, London, WC2H 9JQ, UK.

Telephones: +9945524170 12; +994518648894

Website: https://scia.website/

E-mail: sc.mediagroup2017@gmail.com

(c) The Southern Caucasus Media. NGO RAIDCG. All rights reserved. Reproduction, store in a retrieval system, or transmitted in any form, electronic, mechanic photocopying of any publishing of Southern Caucasus Scientific Journals permitted only with the agreement of the publisher. The editorial board does not bear any responsibility for the contents of advertisements and papers. The editorial board's views can differ from the author's opinion. The journal published and issued by The Southern Caucasus Media. 


\section{Ayten Mekhraliyeva}

CHALLENGES FACING THE CURRENT STATE OF EXPORT POTENTIAL

(IN THE CASE FOR AZERBAIJAN) ...

Жанна Глотова, Лариса Грошева, Валерия Николаичева

К ВОПРОСУ ФОРМИРОВАНИЯ ИНОЯЗЫЧНОЙ ЛЕКСИКО-ТЕКСТУАЛЬНОЙ

КОМПЕТЕНЦИИ В ДИСТАНЦИОННОМ РЕЖИМЕ НА ПРИМЕРЕ РАБОТЫ С

ПРИЛОЖЕНИЕМ РНАSЕ-6 OFFICЕ

Ayten Mekhraliyeva

ANALYSIS AND ASSESSMENT OF AZERBAIJAN'S EXPORT POTENTIAL IN

THE CONTEXT OF ENTREPRENEURIAL ACTIVITIES

Kapanadze Maia, Nozadze Mzevinar

MONEY MARKET AND ITS INSTRUMENTS (ON THE EXAMPLE

OF GEORGIA)

Лиана Птащенко

АКТУАЛИТЕТЫ НЕЙТРАЛИЗАЦИИ УГРОЗ ЭНЕРГЕТИЧЕСКОЙ БЕЗОПАСНОСТИ

УКРАИНЫ

Gulshan Zeynalova

CORRELATION OF OIL AND GAS RESOURCES OF THE CASPIAN COUNTRIES .... 39

Fatimə Şirinzadə

IXRACDA MARKETINQIN ROLUNUN ÖLKӘ SəVIYYӘSINDӘ

QIYMӘTLӘNDIRILMӘSI

Шафаг Асадова, Шарифа Вагабова

КЛИНИКО-ДИАГНОСТИЧЕСКИЕ ОСОБЕННОСТИ ПОСТМЕНОПАУЗАЛЬНОГО

ОСТЕОПОРОЗА У ЖЕНЩИН В УСЛОВИЯХ Г. БАКУ 


\title{
CHALLENGES FACING THE CURRENT STATE OF EXPORT POTENTIAL (IN THE CASE FOR AZERBAIJAN)
}

\section{Ayten Mekhraliyeva}

$\mathrm{PhD}$ candidate at «International Magistrate and Doctorate Center» (IMDC), Azerbaijan State University of Economics, https://orcid.org/0000-0001-8874-719X, Email; Aytenmekhraliyeva18@mail.ru

\begin{abstract}
The purpose of the study is to identify the importance of increasing export activity in ensuring economic development and the main conditions for increasing the country's export potential, to stimulate exports based on an assessment of the current state of export operations. Moreover, the study determines the directions for increasing the country's export potential and improving the legal framework for its use, furthermore, compile the adequate suggestions and recommendations. The report identifies the importance of export activities in the modern system of economic relations; The main conditions for increasing the export potential in the Republic of Azerbaijan and the stimulated means of using the export potential have been studied; the need for legal regulation of state intervention to increase the export potential of Azerbaijan and promote its implementation was substantiated; the system of legislative acts regulating the implementation of export operations was analyzed; the mechanisms of realization of the existing state support in the field of export stimulation in our country have been studied; The directions of improving the legal framework to increase the export potential and stimulate exports have been identified in our country.
\end{abstract}

Keywords: export, foreign relations, economic development, growth, international trade.

Introduction: Observing the rapid growth dynamics of economic development in the country over the past 10 years, directing revenues from the successful oil strategy to the modernization of production infrastructure, the implementation of certain measures to diversify the non-oil sector in the economy, as well as GDP growth and social welfare elevation has occurred. The sharp declines in oil prices on world commodity markets, as well as the crisis of foreign trade partners, have led to a slowdown in economic growth.

In response to the challenges facing the economic development of our country, it is necessary to make a number of institutional and structural improvements. The balance of payments deficit, the negative impact on the financial and banking sector and the non-oil budget deficit have shown the need for the country's transition to a new model of development. For sustainable economic development, it is necessary for the avant-garde sectors to be the locomotive of economic development in our economy, for the trade sector, processing industry, private entrepreneurship, high-tech sectors, as well as highly skilled labor-intensive and value-added sectors to have a special share. It is planned that the improvement in the structure of the economy will be a positive impetus for the development of the business environment, the strengthening of the financial and banking sector and the introduction of a floating exchange rate monetary policy to create conditions for access to international markets. The application of new technologies in industry, management, communications, finance, information and other areas in our country, both in the private sector and in the public sector, can give impetus to the creation of high benefit. 
Along with the import of new technologies, it is possible to increase the export potential and achieve a substantial development in exports by bringing new technology in the labor force that manages the process. Because of the analysis of economic growth, we can see that the oil factor has a significant impact on macroeconomic stability and social welfare. With the implementation of procyclic economic policy, the dependence of economic growth on government demand has increased. One of the main challenges is to replace the role of public demand in economic growth with sustainable private demand.

Modern challenges review: As a measure adequate to the modern challenges facing the Azerbaijani economy, it is especially important to minimize dependence on exports of hydrocarbon resources, increase non-oil exports and close the non-oil import deficit. As a result of the development of the non-oil sector, the volume of exports per capita is planned to reach $\$ 1,000$. To achieve the set goals, it is necessary to carry out effective government regulation that creates a healthy competitive environment and transformation into an exportbased economy that generates high value added. The application of a flexible exchange rate policy can increase the solvency of our country by creating positive impulses in export activities. One of the main challenges facing our country is to improve the mechanisms to protect the rights of investors, eliminate shortcomings in competition law and create a working system.

The raw material orientation of the economic development of the republic leads to the fact that the main part of exports is accounted for by hydrocarbon resources, which are products of the extractive industry. In our opinion, the application of the innovation-technology model can minimize the dependence of the national economy and exports on energy carriers. The low and voluntary nature of commodity prices compared to the products of the processing industry in world commodity markets leads to sharp fluctuations in foreign exchange inflows into the country when exports are based on raw materials, as well as negatively affects the solvency of low foreign exchange earnings. The creation of low added value in a commodity-oriented economy has a negative projection on wages. In developed countries, the use of advanced technologies and the application of innovative technological innovations in production, as well as the high value added created by the participation of highly skilled labor in the production process play a positive impetus in socio-economic development.

One of the modern global challenges is for all mankind to strive to use environmentally friendly alternative energy sources. In OECD countries, this process is faster. Renewable alternative energy sources currently account for $17.5 \%$ of the EU's energy supply. Europe's energy roadmap for the future sets energy efficiency, renewable energy, nuclear energy, carbon retention and storage as key principles for the transition to a sustainable, competitive and secure energy system by 2050 . In order to protect the environment and increase the brand value of companies, companies are switching to alternative energy, and investors are interested in investing more in these companies. Studies show that by 2040-2050, the energy supply of the European Union will be almost entirely using alternative energy sources (https://cleantechnica.com). The use of alternative energy in production can reduce carbon emissions into the atmosphere as a result of the production process. By choosing renewable energy, companies can address carbon emissions, meet energy security targets, and pursue sustainable development goals and science-based priorities. When looking at the structure of the republic's export products, we can see that there are only a few types of refined oil products.

In our opinion, despite the use of alternative energy sources in the future, in the military industry, especially missiles, military aircraft, etc. In the future, the use of oil obtained from oil 
refining in the fuel supply can be considered as one of the challenges that will allow the country to specialize in the export of oil products.

Estimation of annual investments in the oil industry: However, in order to achieve high results in oil refining, first, the technical base of Azerbaijan's oil industry needs to be updated. The basic means of production can be used more than once in the production process, not just once, but several times. If the means of production are used repeatedly in the production process, productivity decreases. This process is called the depreciation of fixed assets. As a result of obsolescence of equipment and machinery, the quality of the product decreases, but the natural shape of the production assets does not change. Depreciation is included in the cost of production because it is incurred during production. Thus, fixed assets are funds that, by repeated participation in production activities, transfer their value in parts to the final product, but do not change their natural form. From the physical point of view, the technical base of the oil industry of the Republic of Azerbaijan needs 70-80\% depreciation of fixed assets. From a moral point of view, the main production assets are completely obsolete. Insufficient investment in the oil industry also plays a role in this situation. Annual investment in the oil industry should make up $25 \%$ of the value of fixed assets in the current year. "While the value of fixed assets in the oil industry in 2017 was 95,307.9 million manat, investment in fixed assets amounted to $8,400.1$ million manat, ie $8.81 \%$ of the total value of fixed assets. As a result, the depreciation rate in 2017 was 28.9\%. In 2018, SOCAR has allocated AZN $10,083,000$ for the renewal of fixed assets"(SOCAR, International Financial Reporting Standards Consolidated financial statements, 31 December 2017).

The low rate of renewal of fixed assets has a number of negative consequences:

- production performance falls.

- accidents often occur in the production process.

- profitability decreases.

- causes loss of time and traumatic injuries to the workforce.

One of the main reasons for the accidents at SOCAR's overpasses is the lack of transparency, as well as the inefficient and unfair use of funds allocated for the repair and construction of overpasses. If SOCAR's overpasses need to be renewed, as well as if oil companies use floating platforms in the international arena, the lack of renewal on expired overpasses can lead to accidents.

SOCAR's newly built and soon-to-be-commissioned Gas Processing Plant at the Gara-Dag Oil and Gas and Chemical Complex has a production capacity of 10 billion cubic meters, as well as a refinery with a production capacity of 10 million tons, as well as 1 petrochemical plant. , Is planned to be 8 million tons. Thus, it is expected that it will be possible to produce fuel that meets Euro 5-6 standards. Along with A-92, A-95, A-98 gasoline, it is planned to produce jet and diesel fuel. The commissioning of the complex can create conditions for increasing the export of refined oil products of our country (www.socar.az). It should be noted that despite the sufficient production capacity of refineries, the small volume of refined oil products is due to the use of only part of the production capacity of refineries. Incomplete utilization of plant production capacity can be considered as one of the important factors influencing the low share of processed products in exports. Maximizing the production capacity of oil refineries is one of the main challenges facing the oil industry's exports.

The analysis of the export potential of agricultural products: It is possible to note some agricultural products of our republic, which have a large export potential. These products 
include pomegranates, figs, potatoes; natural honey, grapes, saffron, walnuts, hazelnuts, etc. can be attributed. It should be noted that saffron products might have promising export opportunities in the future. At present, the demand for saffron in the domestic market is met by products imported from Iran to our country, which negatively affects local production and hinders the development of saffron. In addition, the Cabinet of Ministers on export-stimulated products

The absence of saffron in Resolution 103 has a negative impact on the use of its promising export opportunities. The unique quality of saffron products produced in our country can create conditions for sufficient foreign exchange inflows from the export of this product to our country in the future. The high price of saffron in the world commodity markets will also encourage the development of the saffron industry as a priority agricultural sector, making it one of the main agricultural products exported in the future.

Even saffron products can be found in foreign markets as an Azerbaijani brand. In the future, our country can get large foreign exchange reserves from the export of viticulture and wine products, which have great export potential. However, the lack of competitiveness of wine products in European markets is due to its low quality, as well as the fact that the packaging and advertising of wine products do not meet modern market requirements. Due to the fact that our country is not a member of the WTO, the small export quota for wine and wine products of national origin by different countries also has a negative impact on the use of its export potential.

The establishment of fertile national regimes based on the principle of free access to WTO markets, which creates favorable conditions for free competition by eliminating quantitative restrictions on trade operations and prioritizing the impartiality and transparency of trade policy, by doing important work to maximize the liberalization of international trade, creates conditions for compliance with the rules, as well as the effective organization of trade turnover through the abolition of quantitative restrictions on imports, as well as increased transparency in the conduct of foreign trade operations by members of the organization (Bayramov V., 2010).

Prospects for accession to WTO: Our country's membership in the WTO is one of the important directions of economic policy and one of the main global challenges facing it. The main goals of our country's membership in the WTO and the main issues to be considered during the membership process are as follows:

- rapid integration into the global economy;

- the benefits of reciprocal concessions of member states gained;

- creation of conditions for conducting trade activities on more favorable terms by organizing trade operations on the basis of general rules;

- access to assistance from international organizations and member states in the process of economic reforms;

- to attract large amounts of foreign investment to our country;

- $\quad$ to be able to benefit from WTO dispute resolution mechanisms;

Our country's membership in the WTO requires the harmonization of the country's legislation with international legislation and the improvement of laws that do not meet international standards. In the field of regulation, the protection of intellectual property, as well as the improvement of laws on foreign investment are important. The benefits that the Republic of Azerbaijan will gain from joining the WTO can be grouped as follows:

- the export potential of our country will increase and the opportunities for exporters to realize their export potential will increase. 
- no ban on trade relations may be imposed on our country by the members of the organization.

- $\quad$ procedures applied in both domestic and foreign trade activities will be simplified.

- monopolies will be reduced, monopolies will be eliminated and a competitive market environment will be created.

- customs tariffs will be reduced; prices for imported goods will be reduced.

There are also criticisms that the application of low tariffs as a member of the organization has weakened local production, which is protected by protectionist methods, and that these producers are unable to maintain their position in the market. However, trade liberalization does not mean the complete abolition of customs barriers, and 7-8 WTO instruments can be used to protect domestic production. It should also be noted that the actual customs duties are in the range of $0 \%-15 \%$, and in international practice there are import rates that are 1.5-2 times higher than the actual rate on the basis of bound rates of the CIS countries. During the negotiations, the Azerbaijani side proposed to impose import customs duties at a minimum of $0 \%$ and a maximum of $25 \%$. In the worst case, even if the bound rates proposed by the WTO are adjusted to the actual rates, our domestic production will have the same negative impact on imports today as it did after accession. In our opinion, even if the status quota is maintained, domestic production will not have a significant negative impact. The increase in imports can be limited by regulatory tools. If the necessary legislation and institutional framework are in place, it is possible to protect domestic production from adverse effects.

Some economists believe that WTO membership will have a negative impact on the country's agricultural sector. According to these economists, certain limits will be applied to state subsidies to agriculture. In many countries around the world, such as the United States, the European Union and Japan, the development of the agricultural sector is possible with state support. State support for the agricultural sector in our country is at a lower level, mainly through subsidies. In the process of joining the WTO, the most controversial issue is the subsidization of agricultural exports.

Constraints in local market: Membership is expected to help lower domestic prices by strengthening the fight against low-quality products in the domestic market and strengthening food security, low tariffs and transparency, rapid productivity growth, and the establishment of a competitive market conductor.

After our country becomes a member of the WTO, Azerbaijani exporters can benefit from the following advantages in export activities:

- To use rich information resources with the help of WTO institutions and to achieve a fair settlement of disputes arising in the course of trade activities;

- possibility of guaranteed access to the domestic market of the member countries of the organization;

- to act as an equal member in multilateral trade negotiations, as well as to gain opportunities to influence world trade (Ibadoglu G., 2017, p. 13);

Azerbaijani importers will have the following advantages:

- minimization of import duties is expected to increase competitiveness in the domestic market;

- possibility for consumers to get higher quality and lower price products and services.

- low tariff rates lead to a mini-mummification of the final cost of goods and materials, as well as semi-finished products and complexes, as well as the final cost of the work (service), resulting in lower prices for products (Ibadoglu G., 2017, p. 13); 
In the process of integration into the world economy, WTO membership is planned to create the following losses for our Republic:

- low competitiveness of products and services is expected to leave the market.

- tax and customs revenues of the state budget may be reduced.

- due to the use of patents in the import of advanced technologies, the presence of commission costs may increase the costs of the industry and reduce revenues.

- the gradual abolition of state support for the development of local industry over time may create conditions for an adequate adaptation crisis (Ibadoglu G., 2017, p. 14).

Identifying the challenges facing the current state of export potential can be done by studying the use of foreign experience in the field of export stimulation.

\section{REFERENCES}

1. CESD, "Small and Medium Entrepreneurship in Azerbaijan; Country Assessment", 2012, www.cesd.az;

2. Decree of the President of the Republic of Azerbaijan on further improvement of management in the field of small and medium business, Baku - 2017.

3. Economic Reform Analysis and Communication Centerhttp://iqtisadiislahat.org/ (dateaccessed: 08/06/2021).

4. Entrepreneurship Development Fund of the Ministry of Economy of the Republic of Azerbaijanhttp://edf.gov.az/ (dateaccessed: 08/06/2021);

5. Law of the Republic of Azerbaijan on Entrepreneurship, Baku - 1992.

6. Law of the Republic of Azerbaijan on state support for small business;

7. Regulation on the adoption of "Rules for the determination of large, medium and small entrepreneurship" Decision of the Cabinet of Ministers of 5 June 2015;

8. Regulation on the adoption of "Rules for the determination of large, medium and small entrepreneurship" Decision of the Cabinet of Ministers of 5 June 2015;

9. Small and Medium-Sized Business: Foreign Development Experience // Young Scientist. - 2012. - №4. - p. 177-181;

10. State Customs Committee of the Republic of Azerbaijan https://customs.gov.az/az (dateaccessed: 08/06/2021).

11. Strategic Road Map on Production of Consumer Goods at Small and Medium Enterprises in the Republic of Azerbaijan 2016;

12. Strategic Roadmap for the production of consumer goods at the level of small and medium enterprises in the Republic of Azerbaijan, Baku - 2016.

13. İITKM (2019, Yanvar ) "İxrac icmalı" Bak1, №1 (22) 30 səh.

14. İqtisadiyyat Nazirliyi (2018), «AZPROMO», "Illlik hesabat” Bakı, 60 səh.

15. İbadoğlu Q. İqtisadi Tədqiqatlar Mərkəzi "Xırda sahibkarlıqda patent vergi sisteminin tətbiqi nələr vəd edir?” elmi araşdırma, 26 səh. 


\title{
К ВОПРОСУ ФОРМИРОВАНИЯ ИНОЯЗЫЧНОЙ ЛЕКСИКО- ТЕКСТУАЛЬНОЙ КОМПЕТЕНЦИИ В ДИСТАНЦИОННОМ РЕЖИМЕ НА ПРИМЕРЕ РАБОТЫ С ПРИЛОЖЕНИЕМ РНАSЕ-6 OFFICE
}

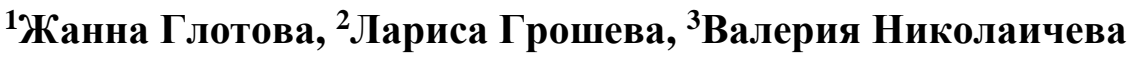 \\ 1,2,3Кандидат педагогических наук, доцент \\ 1,2,3Балтийский федеральный университет им.И.Канта, Калининград, Россия \\ Email: ${ }^{1}$ ZHGlotova@kantiana.ru, ${ }^{2}$ LGrosheva@ kantiana.ru, ${ }^{3}$ VNikolaicheva@ kantiana.ru
}

\section{РЕЗЮМЕ}

В заявленном сообщении рассматриваются некоторые вопросы, связанные с формированием первичной иноязычной лексико-текстуальной компетенции в рамках изучения иностранного языка. Авторы обращаются к описанию принципов и этапов формирования общей лексико-текстуальной компетенции. В статье приводятся примеры упражнений, имеющих своей целью сформированность лексико-текстуальной компетенции на основе работы с электронным приложением phase -6 Office, представленным в 2021 году издательством Klett. Авторы делают вывод, что тренируемый вокабуляр запоминается обучающимися намного быстрее и менее разрозненно. Одновременно с совершенствованием лексических навыков формируется текстуальная компетенция, где развивается способность обучающихся определять контекстуальное значение слова, сравнивать значения на двух-трех языках.

Ключевые слова: компетенция, компетентность, лексико-текстуальная компетенция, вокабуляр, словарные пакеты, словарные коллекции.

Вопросам формирования лексической и текстуальной компетенциям или компетентностям всегда уделялось и уделяется пристальное внимание исследователей (Шамов А.Н., Серова Т.С., Мясников А.А., Архипова Е.И. и др.). Безусловно, обучение лексике является одной из важнейших составляющих всего процесса обучения иностранному языку и именно на этом компоненте делается основной акцент преподавателями иностранного языка. Несмотря на то, что не существует единого определения лексической компетенции / компетентности, авторы все же едины в понимании сущности этого определения, понимая под ним весь потенциал личности общаться на основе имеющейся у нее основной лексической базы. Поэтому овладение иностранным языком в целом и овладение лексическим аспектом в частности должно протекать как взаимодействие людей между собой и окружающим миром [1].

Считаем целесообразным, вслед за многими учеными, рассматривать процесс формирования именно лексико-текстуальной компетентности (а лексику нельзя рассматривать отдельно от текста, вне контекста) как умения, основанного на лексических знаниях, речевых лексических навыка и умениях, а также личном языковом и речевом «багаже»; как способность к восприятию, усвоению и употреблению лексикона в определенных общеязыковых или профессионально-маркированных ситуациях. В рамках данного сообщения лексико-текстуальная компетенция понимается 
как способность не только запоминать слова в контексте, но и связывать их в единое смысловое высказывание в устной и письменной речи.

Следует отметить, что весь предыдущий год все педагогическое сообщество находилось в поиске форм, методов, средств, технологий обучения в удаленном режиме. В период дистантной работы с обучающимися необходимо было искать новые мотивационные «стимуляторы» по работе с иностранным языком, которые имели бы не только развлекательно-игровой вектор, но и создавали бы устойчивый познавательный интерес на принципе сознательности обучения. Позволим себе перейти непосредственно к электронному приложению phase -6 Office, которое очень удачно, на наш взгляд, использует немецкоязычное издательство Klett. Данное издательство проделало за предыдущий год огромную работу относительно создания онлайн-материалов, программного обеспечения для обучения всех уровней (от начальной школы до бизнеса), онлайн-тестов, цифровых учебников, медиатеки и многих других материалов. Но самое главное, что появилось в 2021-2021 гг., это словарные пакеты для phase -6 [3].

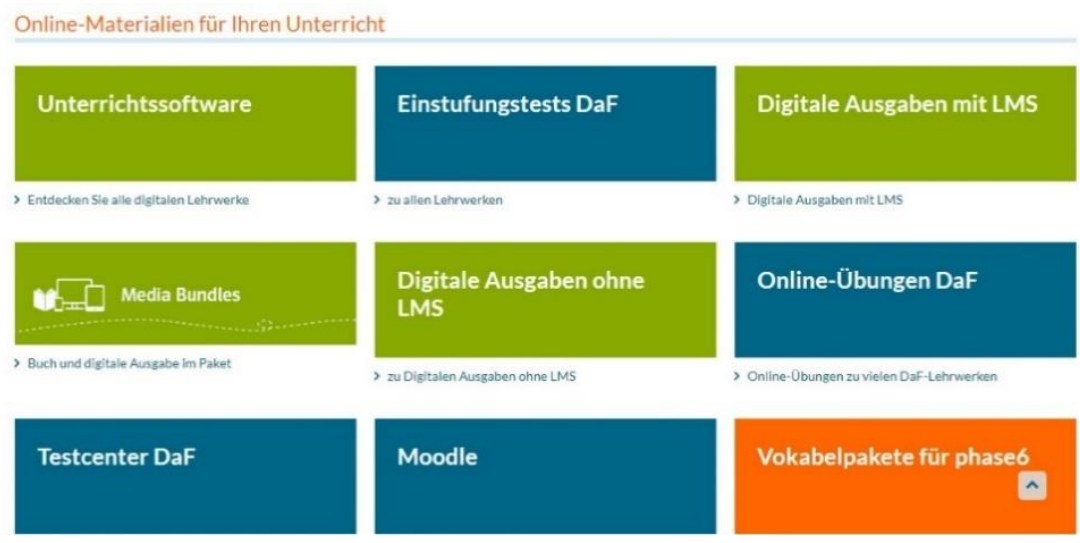

Рис.1 Онлайн-материалы для занятий ИЯ

Эти словарные пакеты существуют более чем на 20 языках, для тренировки можно выбирать разные языковые пары, с которыми обучающийся хочет работать.

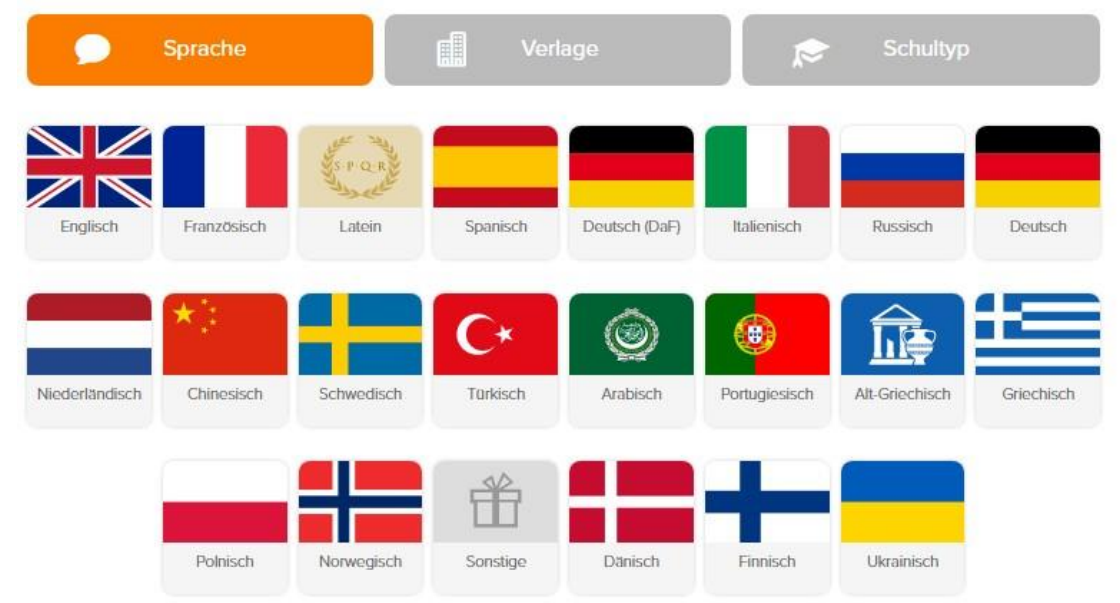

Рис. 2 Языки приложения phase - 6 


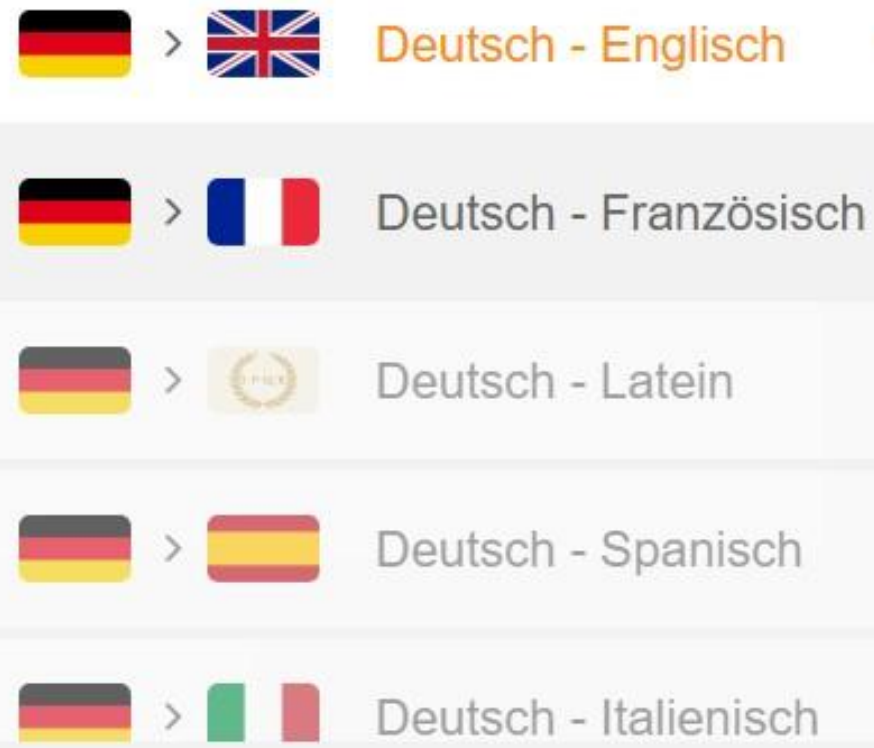

Рис. 3 Примеры языковых пар

Следующий рисунок демонстрирует издательства. с которыми работает Klett и для учебных пособий которых имеются словарные пакеты.

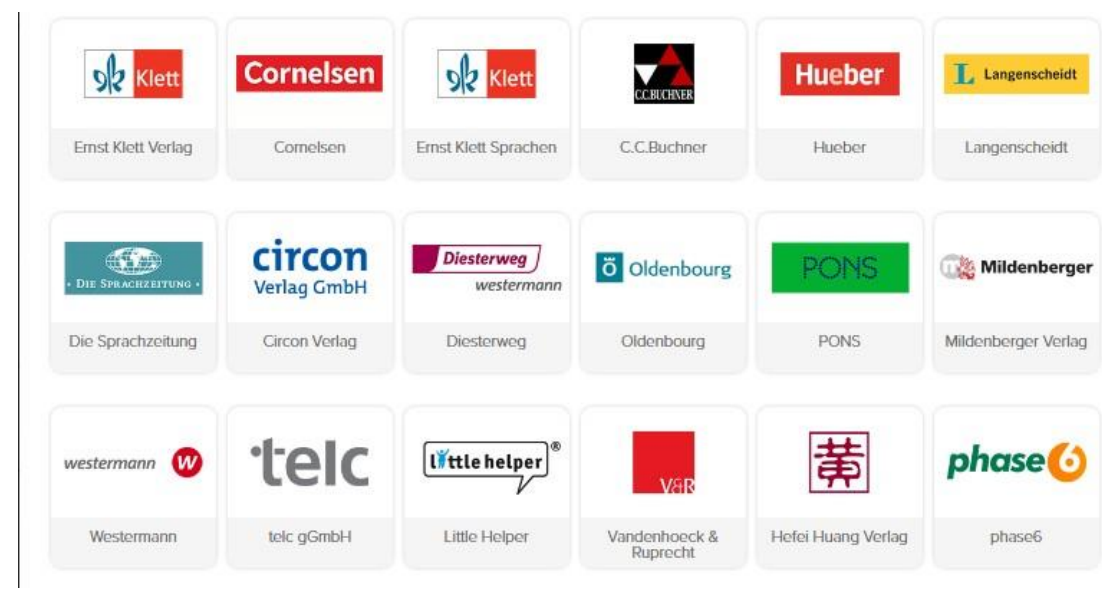

Рис. 4 Издательства

Обучающиеся выбирают неободимый для себя словарный пакет, который может использоваться абсолютно автономно, а может быть привязан к определнному учебному пособию, изданному одним из вышеназванных издательств. 


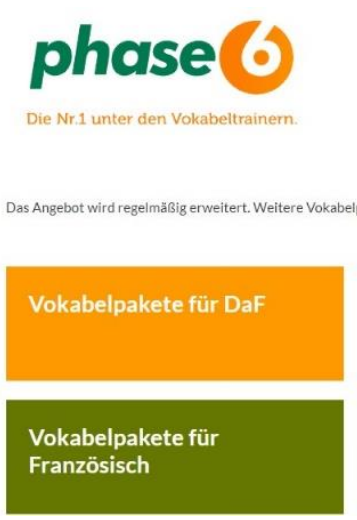

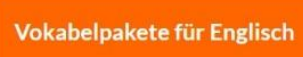

Vokabelpakete für Italienisch
Vokabelpakete für Spanisch

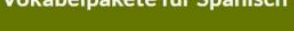

Vokabelpakete für weitere. Sprachen

Рис. 5 Словарные пакеты для различных языков

Интерфейс электронного приложения phase -6 очень прост.

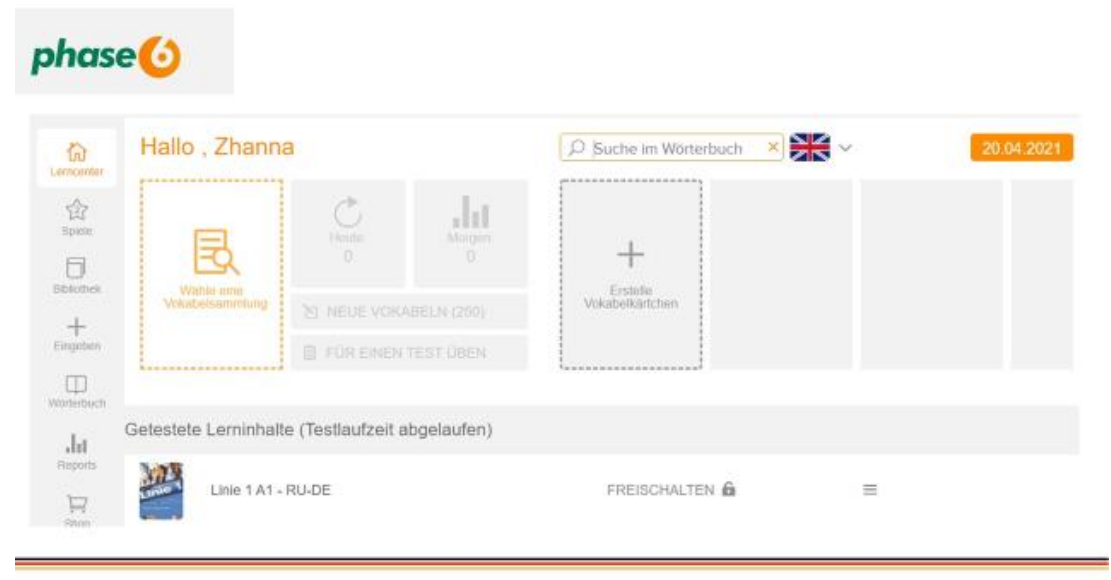

Рис. 6 Интерфейс приложения phase -6

Говоря о полноценном процессе формирования лексико-текстуальной компетентности на основе phase - 6 Office, эффективнее выбирать определенное учебное пособие, которое будет способствовать заучиванию лексики в контексте, соблюдая принцип тематической обусловленности.

Приведем в пример цифровое учебное пособие Linie A1.1, которое используется для обучающихся на уровне А 1 согласно Общеязыковой европейской рамке компетенций владения иностранным языком [4]. 


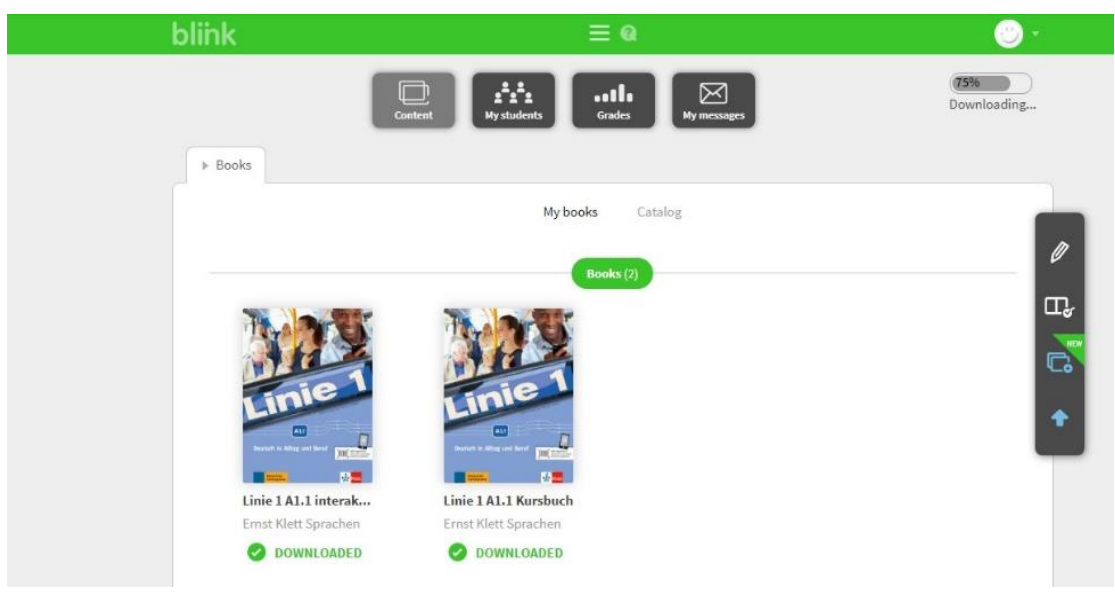

Рис.7 Цифровое уебное пособие Linie A 1.1

Мы видим контент пособия, группу обучающися пофамильно, их успеваемость и сообщения между участниками курса. На следующем рисунке мы видим сам контент пособия, который наполнен восемью уроками-темами. При нажатии на кнопку «Digitales Buch» открывается полны урок со всеми упражнениями, текстами, аудиофайлами. Дается 3 попытки для выполнения заданий, из которых потом вырисовывается общая картина успеваемости каждого обучающегося и степень освоения материала.

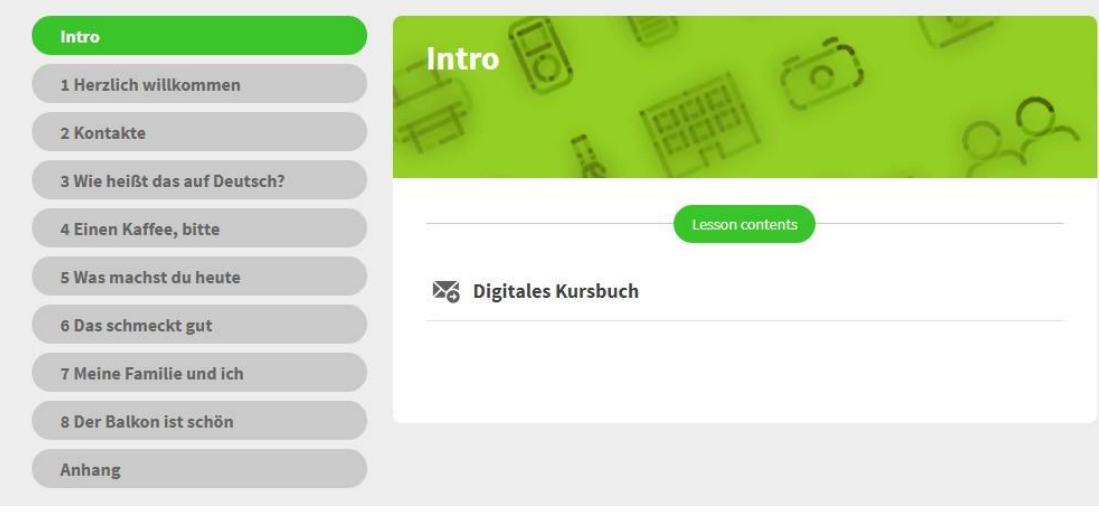

Рис. 8 Контент учебного пособия Linie A 1.1

Учебное пособие построено так, что формируются все четыре основные навыка чтение, письмо, аудирование и говорение. Ниже можно увидеть две страницы пособия в развороте, где имеются свои инструменты для работы: можно выделять текст, писать свои комментарии, слушать аудиозаписи, не открывая дополнительных страниц. 


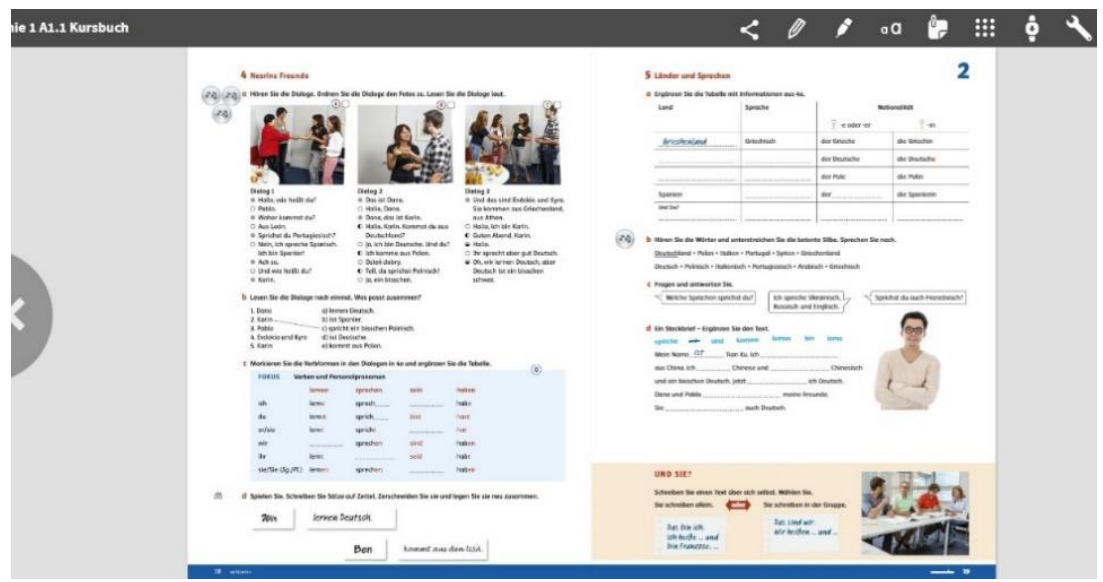

Рис. 9 Пример урока из учебного пособия Linie A 1.1

В помощь по освоению лексики, которая предъявляется в конце каждого урока, предлагается словарный пакет к данному пособию. Можно самому выбрать тему и работать над словами. Сначала обучающемуся необходимо выбрать словарную коллекцию, он сам может создавать учетные карточки с переводом, находить соответствия, пары.

Конечно, нельзя сказать, что представлена полная палитра возможных заданий, но это, на наш взгляд вполне достаточный набор. После предъявления затем закрепления лексики можно пройти тест и убедиться, насколько ты хорошо овладел необходимой лексикой. Здесь изучается самостоятельно и конкретно лексика, с которой потом обучающийся будет иметь дело в аудитории или в рамках автономной работы над конкретным уроком.

Phase - 6 предлагает более 1000 коллекций словаря, подходящие материалы для всех. Изучение словарного запаса c phase - 6 аналогично изучению словарного запаса с помощью учетных карточек. Тренажер основан на личном уровне знаний, сложные слова повторяются чаще, чем те, которые уже хорошо известны.

Студенты отмечают, что изучение словарного запаса с приложением phase - 6 эффективнее. Тренируемый вокабуляр запоминается обучающимися намного быстрее и менее разрозненно. Одновременно с совершенствованием лексических навыков формируется текстуальная компетентность, где развивается способность обучающимися определять контекстуальное значение слова, сравнивать значение на нескольких языках [2].

В рамках обсуждаемой темы автор делает акцент и на этапности формирования лексикотекстуальной компетенции: накопление лексических единиц, отработка навыка в упражнениях, применение в рамках текста различной направленности.

Первый этап формирования лексико-текстуальной компетентности подготовительный. На данном этапе преподавателем предъявляются такие упражнения, где новая лексика только презентируется. В начале работы над каждой темой обучающиеся только знакомятся с новой лексикой. На данном этапе студенты выполняют ряд лексических упражнений, в ходе которых они, например, должны установить тему сообщения или текста, соотносить лексические единицы на русском и иностранном языках, выделять значимые слова в заголовках текстов или в отдельных пассажах, систематизировать лексику на общеупотребительную или специальную. Для развития речевых лексических умений можно использовать вопросно-ответные 
упражнения, которые позволяют заучивать слова не изолированно, а в тесном текстовом окружении.

Второй этап формирования лексико-текстуальной компетентности - собственно текстовой. На данном этапе работа обучающихся сосредотачивается на учебном тексте. На этом этапе должно происходить осмысленное усвоение лексически единиц в их синтагматических отношениях. Здесь можно предложить такие виды упражнений: попросить обучающихся поделить текст на смысловые части, назвать все ключевые слова, передающие смысл всего текста или его отдельной части; перевести сложные лексические единицы с русского языка на иностранный или наоборот; зафиксировать текст в виде конспекта или тезисов; трансформировать изучаемые лексические единицы в другой грамматический контекст.

Третий этап - коммуникативный. На данном этапе происходит отработка речевых лексических умений в монологической или диалогической речи. Целью данного этапа развить компетенцию прогнозирования у обучающихся относительно угадывания тематики текста по ключевым словам или заголовку; отработка умения письменного или устного реферирования текста. Потенциальные упражнения на этом этапе должны в полной мере отражать психологическую готовность беседовать на заданную тему в зависимости от конкретной коммуникативной ситуации и создавать оформленное письменное речевое произведение в виде сочинения, сообщения, рассуждения и т.д.

Четвертый этап - учебно-моделирующий этап. На данном этапе предлагаются конкретные учебные, учебно-профессиональные или профессиональные ситуации, в которых обучающиеся могли бы в группе, в команде решать реальные кейсы на основе уже сформированной лексико-текстуальной компетентности.

В заключение делается вывод о том, что работа с приложениями такого типа, как phase6 Office позволяет эффективнее, осознаннее накапливать лексику, отрабатывать ее многократно, до полного закрепления с учетом своего индивидуального продвижения и осуществлять трансфер полученных навыков на новый материал.

\section{ЛИТЕРАТУРА}

1. Агальцова Д.В. Использование интерактивных приложений для работы с новым лексическим материалом // Мировое культурно-языковое политическое пространство: инновации в коммуникации: сборник научных трудов. - М., 2017. - C.123-126.

2. Клепикова Т.А. «Лингваториум»: инновационный адаптивный компьютерный лексический тренажер // Инновационный контекст развития методики преподавания иностранных языков, филологии и межкультурной коммуникации: материалы научно-практической конференции с международным участием. СПб.: Книжный дом, 2013. - С.13-19.

3. Vokabeltrainer zum Buch von Hueber [Электронный pecypc]. -URL: https://www.phase6.de/classic/lerninhalte/vokabeltrainer/hueber/Selbstlerner/ (дата обращения: 20.04.2021).

4. Linie 1 - aktiv und sicher zur Integration [Электронный pecypc]. URL:https://www.klett-sprachen.de/linie 1/400\#reiter=titel\&niveau=EinstiegA1 (дата обращения: 20.04.2021). 


\title{
TO THE ISSUE OF CREATING A FOREIGN VOCABULARY AND TEXTUAL COMPETENCE IN REMOTE MODE USING THE EXAMPLE OF WORKING WITH THE PHASE-6 OFFICE APP
}

\section{${ }^{1}$ Zhanna Glotova, ${ }^{2}$ Larisa Grosheva, ${ }^{3}$ Valeriya Nikolaicheva 1,2,3 Immanuel Kant Baltic Federal University, Kaliningrad, Russia}

\begin{abstract}
The communication addresses some issues related to the formation of primary foreign language vocabulary and textual competence in the context of foreign language learning. The authors turn to the description of the principles and stages of the formation of general lexicaltextual competence. The article provides examples of exercises aimed at forming a lexicaltextual competence based on working with the electronic app phase - 6 Office, introduced in 2021 by Klett. The authors conclude that the trained vocabulary is remembered by students much faster and less disparate. Simultaneously with the improvement of lexical skills, textual competence is formed, where the ability of learners to determine the contextual meaning of a word develops, to compare values in two or three languages.

Keywords: competence, competence, lexical-textual competence, lexicon, dictionary packages, dictionary collections.
\end{abstract}




\title{
ANALYSIS AND ASSESSMENT OF AZERBAIJAN'S EXPORT POTENTIAL IN THE CONTEXT OF ENTREPRENEURIAL ACTIVITIES
}

\section{Ayten Mekhraliyeva}

$\mathrm{PhD}$ candidate at «International Magistrate and Doctorate Center» (IMDC), Azerbaijan State University of Economics, https://orcid.org/0000-0001-8874-719X, Email: Aytenmekhraliyeva18@mail.ru

\begin{abstract}
Entrepreneurship is one of the most important factors in the formation and development of a market economy, supporting the domestic market. It can solve social problems along with the solution of an important socio-political task - the formation of the middle class, the strengthening of democracy and social institutions, small business. In modern conditions, the intensification of state regulation and the promotion of the development of entrepreneurship, the organizational forms of interaction of government agencies with private entrepreneurship are changing. During this work, there are significant changes in the goals, mechanisms, management apparatus in the combination of state and market regulatory mechanisms, which is necessary to talk about the importance of the analysis of the structure of activities.

In order to accelerate the pace of economic development in Azerbaijan, to apply the improved features of the market economy, the importance of free entrepreneurship, especially innovative entrepreneurship in accordance with the requirements of the time, is very high. Because innovative entrepreneurship allows to increase low production capacity and product quality. The goals and objectives of the research are to study the specifics of the activities of small and medium-sized businesses in Azerbaijan, to identify their origin, principles of operation, and their specific features. It is also the subject of research to determine the main directions of export activities of business entities and their impact on foreign economic activity, the volume of import-export operations and trade turnover of the country.
\end{abstract}

Keywords: entrepreneurship activity, Azerbaijan's export policy, economic development, SME, market economy,

Introduction: Following the current trends in the economic development of the Republic of Azerbaijan, it can be seen that foreign trade relations are growing. In particular, the policy of achieving diversified economic development accelerates the relevance of foreign trade. In general, foreign trade as a concept involves the exchange of goods and services provided by Azerbaijan in trade relations with other countries through the payment of the material value, as well as the import and export to Azerbaijan. Most of the value added in the international economy today comes from international trade, which is more clearly expressed in the opinion of American economist Jeffrey Sachs. Thus, he notes, the economic gain and success of any country depends on foreign trade. No country has been able to form a perfect economy outside the system of modern world economic relations. Foreign trade operations, which act as the primary form of Azerbaijan's international trade relations, were created under the influence of international specialization of labor relations. Such specialization has resulted in the exchange and exchange of goods and services produced in Azerbaijan, as well as in other countries. As we know, in the current situation, foreign trade relations are very important for the Azerbaijani 
economy. Azerbaijan mainly earns its income from the sale of oil and oil products in foreign trade. Foreign trade acts as a source of income for Azerbaijan and creates great opportunities for economic development and growth. At the same time, the large share of foreign trade in the country's revenues creates a certain dependence on the world economic system. The deepening of globalization is also felt in this way [5].

\section{The role of foreign economic relations in the development of the Azerbaijani economy:}

Azerbaijan's economy is undergoing a rapid integration process and is closely involved in building close relations with countries around the world. In particular, trade relations with European countries have been growing rapidly since the first years of independence. It is no coincidence that if we look at Azerbaijan's export statistics, we can see that Italy ranks first as a foreign trade partner. Implemented regional energy and transport-infrastructure projects give a serious impetus to Azerbaijan's economic development. The volume of budget revenues is growing significantly. However, as well as the positive aspects of deep integration into the world economic system, there are a number of negative effects. Thus, the sharp decline in prices on the world market of oil and oil products since 2015 has created very serious difficulties in countries that provide their income through the sale of energy resources in the world $[1,2]$.

Azerbaijan was also among the countries facing these difficulties. Among the difficulties that arose were the depreciation of the national currency, a slight increase in inflation, and a decrease in budget revenues in dollar equivalent. However, as a way out of these difficulties, the government has focused on the supply of goods and services in foreign trade relations from areas presented as the non-oil sector instead of energy raw materials. In particular, various presidential decrees and decrees have been issued to enhance the role of the private sector, as well as development programs. In addition, one of the steps taken to ensure declining public revenues from various sources is the privatization of state property. In particular, in 2016, a large number of state property was privatized. Naturally, as a market economy, Azerbaijan must achieve a statistical "victory" over the public sector in the private sector in accordance with the requirements of the modern economic system. That is, private sector enterprises and all economic entities must play a leading role in ensuring public revenues. This factor will once again have a positive impact on overcoming economic problems, achieving economic growth and improving the living standards of the population in Azerbaijan, which depends on the proceeds from the sale of oil and oil products in foreign trade.

Generally, Azerbaijan's foreign trade turnover has exceeded $\$ 30$ billion at various times. This in itself indicates the extent of economic potential. During the main periods of trade, especially as shown in Figure 1 below, exports were higher than imports. However, as noted above, trade turnover has generally declined in recent years [4].

However, the country's leadership's quick response to declining revenues and the steps taken to compensate for declining oil revenues have consistently borne fruit. In particular, a number of development programs, roadmaps and government measures related to the implementation of development strategies indicate promising development.

The positive aspects of the intensification of foreign trade operations and diversified exports in Azerbaijan and their role in economic development can be assessed from various aspects. Thus, the role of foreign trade in improving the living standards of the population is measured by the level of their income and the benefits they receive as a result of high-quality standards applied to products. Success in foreign trade is achieved when the quality of products meets at least world standards. 


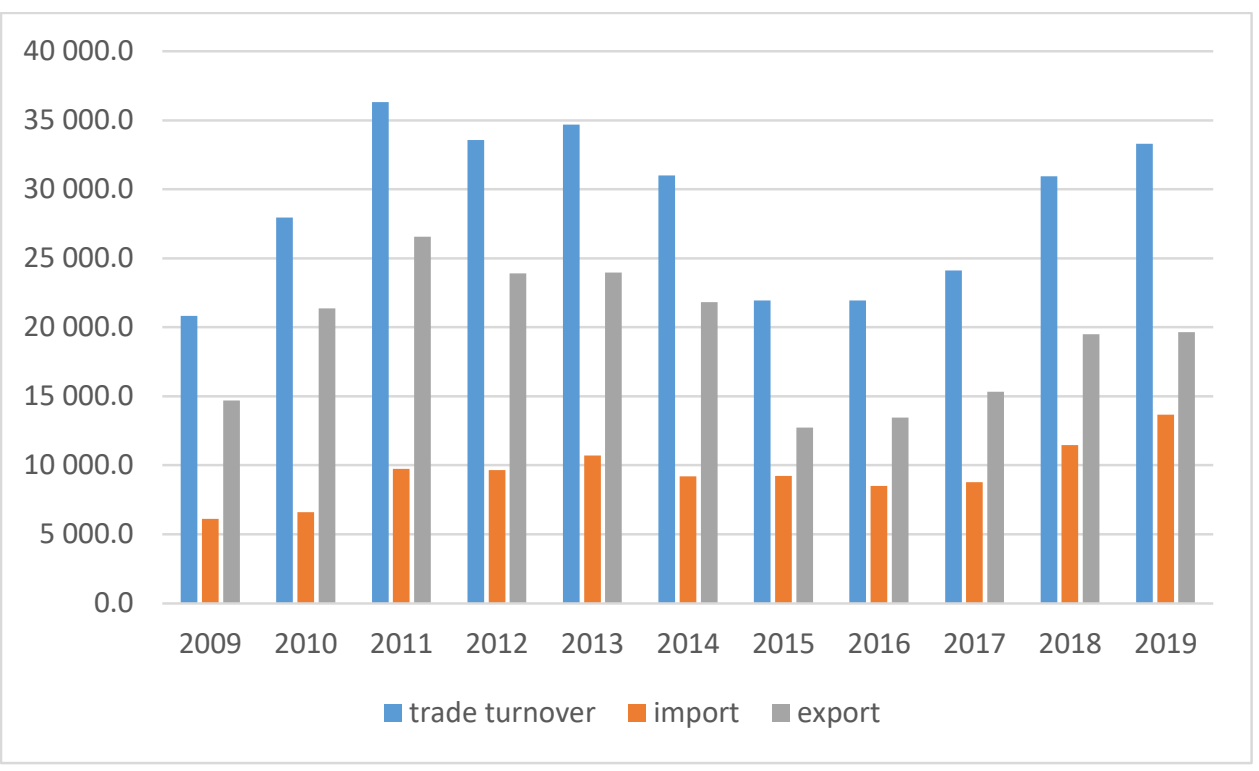

Fig 1. Dynamics of foreign trade turnover (in millions of US dollars)(Source: compiled by the author based on site data https://www.stat.gov.az/source/trade/)

As it's known, a country that is a trading partner buys goods and services in order to meet the needs of its citizens. International trade operations should be understood as the international exchange of various products between many countries. In general, foreign economic relations at the international level are the sphere of international commodity-money relations, the sum of foreign trade of all countries included in the world economic system [6,7].

Azerbaijan's foreign trade activity consists of two reciprocal processes, export and import. In Figure 1, we observed the total trade turnover, as well as the volume of import and export transactions. These operations also include the share of private sector enterprises. Thus, the main participants in the establishment of international trade relations of Azerbaijan are foreign trade entities, the state itself, industrial and production groups, as well as individuals and others. They can also be called exporters or importers. In general, Azerbaijan's foreign trade relations are assessed as a multifaceted activity.

It should be noted that in international practice, goods traded as objects of trade in foreign trade operations are classified according to their specific features or according to the criteria of product specialization. When looking at economic research and scientific research, it is possible to come across different group classifications. Such classifications reflect different types and forms of foreign trade.

From these classifications we can summarize and present the following:

$>$ foreign trade activities for the sale of finished products;

$>$ foreign trade activities on production machines, as well as equipment;

$>$ foreign trade activities for the sale of raw materials;

$>$ foreign trade activities for the provision of services [8].

Depending on the types of import and export operations carried out by economic entities of the Republic of Azerbaijan, especially with the participation of small and medium enterprises, we can distinguish the following groups of foreign economic trade relations:

1. trade operations on export and import of finished goods; 
2. export of goods and semi-finished products from the country in the form of raw materials for further processing; re-entry into the country after processing;

3. activities on temporary import and export of goods, export of goods to international competitions, exhibitions, presentation events, export from the country for the purpose of demonstration and subsequent re-import;

4. carrying out re-export operations to re-export;

5. Activities on export and import of goods belonging to transnational companies belonging to Azerbaijan;

6. activities on mutual compensation trade between countries;

7. transactions on exchange of goods without currency;

8. cash-based trade and compensation transactions;

9. industry compensation agreements [10].

Assessment of the current state of export operations: Foreign economic relations are a number of directions, forms, methods and means of monetary, financial and credit relations, as well as trade, economic, scientific and technical cooperation between countries to strengthen the advantages of the international division of labor, increase the efficiency of economic and entrepreneurial activities. Foreign economic relations are linked to economics and politics, trade and diplomacy, trade and industrial production, scientific research, credit and financial operations.

Foreign economic relations of business entities cover the following directions and forms [12, p. 245]:

$>$ foreign trade;

$>$ international industrial (agrarian and industrial) cooperation;

$>$ international investment cooperation;

$>$ international scientific and technical cooperation;

$>$ economic and technical assistance;

$>$ monetary and financial cooperation.

$>$ In general, the system of regulation of foreign economic activity operates at five levels:

$>$ Micro level - covers the activities of legal entities and individuals engaged in the export or import of goods and services;

$>$ meso level - the level of various national branches and regional associations. This includes, above all, ministries and agencies directly involved in the regulation of foreign trade, as well as departments and bodies that play an active role in regulating export or import tariff regulation in particular;

$>$ The macro level is the state level. At this level, of course, the government and parliament act as key actors;

$>$ meta level - is the establishment of international regional integration customs and tariff priorities. This is especially true of cooperation between the customs authorities during the establishment and development of the Customs Union;

$>$ mega level - regulation at the level of international associations and organizations.

The development trend of foreign economic relations of the world countries shows that foreign economic and trade relations have historically played an important role in changing the socioeconomic situation of states for the better. In the world practice, protectionist trade policy and free trade policy are distinguished depending on the scope of the country's interference in foreign economic and trade relations. Protectionism is a state policy implemented through the use of tariff and non-tariff instruments of trade policy to protect the country's domestic market from competition with foreign entities. Free trade relations are a state policy that reflects the 
lowest level of state intervention in foreign trade, developed on the basis of free market principles under the influence of supply and demand. As we know, in a market economy, the state regulates foreign economic relations in order to ensure economic security and protect the national interests of the country. Depending on the criteria of state regulation of foreign economic and trade activities, it is carried out using a number of methods [11, p. 138]. Methods of regulating foreign economic activity are also included in its system of regulation. These methods include the following:

$>$ economic;

$>$ administrative,

$>$ tariff and non-tariff $[9,11]$.

In Azerbaijan, each method is used in order to stimulate the foreign economic activity of business entities and ensure the intensity of relations. The state provides representatives of business entities with opportunities such as tax, customs benefits, as well as exemption from various duties. Organizational support for export activities of entrepreneurship can also be considered as part of this regulation.

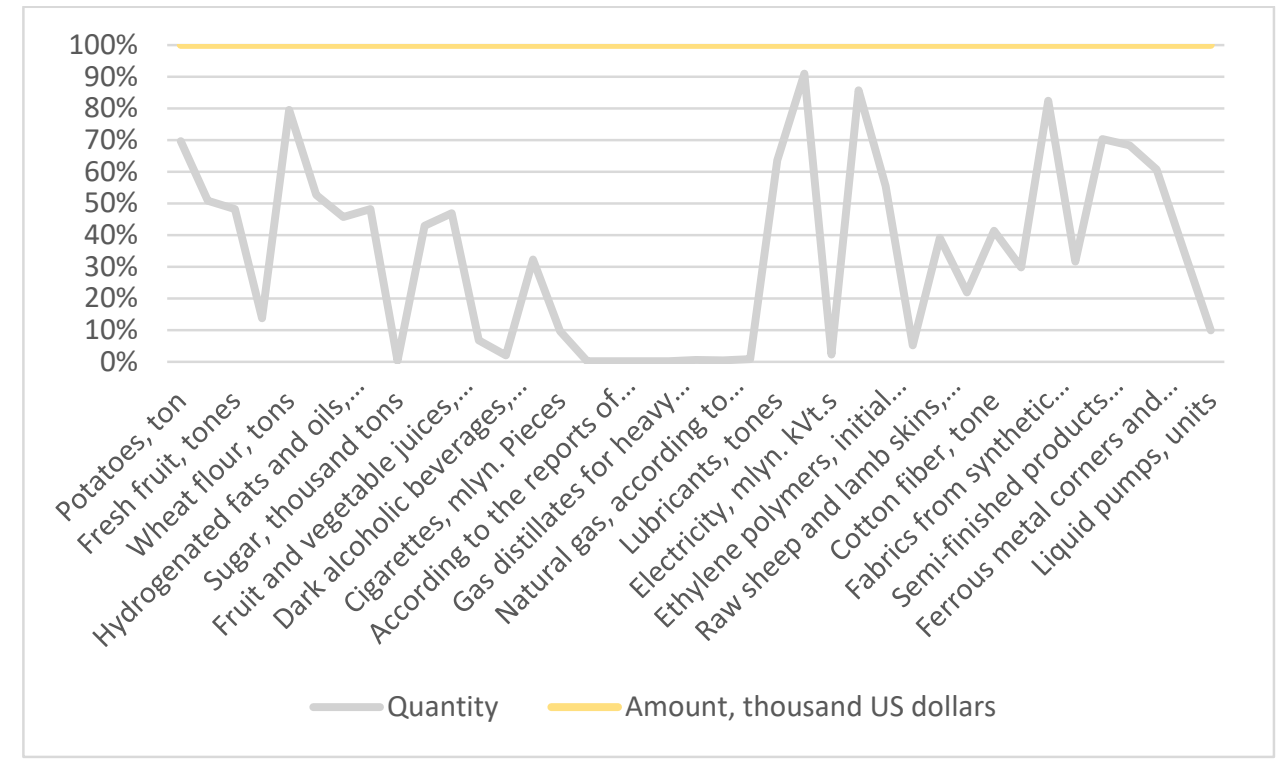

Fig 2. Dynamics of exports of basic goods in percentage for 2019 year.

(Source: compiled by the author based on site data https://www.stat.gov.az/source/trade/)

Taking a view at the main goods what are exported in 2019 year we clearly notice there're many constraints and risks in exports of many products, essentially, paper and cardboard and products made of them, ferrous metal corners and channels, raw sheep and lamb skins, bags and packages of textile materials, wheat flour and etc. (Fig.2).

Within the framework of the support policy, all government agencies serve the implementation of a unified economic policy, i.e., the realization of the country's export potential, as well as reducing dependence on imports, while prioritizing the quality of imported products. One of the tools included in the system of regulation of foreign economic and trade relations of business entities is tariff regulation. We can distinguish the specific features of this regulation in Azerbaijan: 
To increase the efficiency of the commodity structure of import operations carried out by business entities in the Republic of Azerbaijan;

$>$ to control the import and export of products in the Republic of Azerbaijan, as well as the ratio of income and expenses in foreign currency to the amount spent by the country;

$>$ To effectively control the process of import and export of the country's foreign exchange reserves and wealth in the customs territory of Azerbaijan;

$>$ To provide opportunities to ensure efficiency in the structure of production and consumption of goods in Azerbaijan;

$>$ To protect national production entities from negative external influences in the conditions of intensification of competition at the international level;

$>$ To create a fertile environment for the effective integration of the country's economy into the world economic system through the participation of national entrepreneurship and economic entities $[11,13]$.

\section{The system of state regulation of foreign economic relations of business entities in}

Azerbaijan: The main purpose of state regulation of foreign economic activity of business entities is as follows [13, pp. 156 - 175]:

$>$ Accelerate the improvement of the market economy through the use of foreign economic relations in Azerbaijan;

$>$ Assistance in increasing the quality and productivity of national products through the acquisition of licenses and patents, the acquisition of new technologies, quality components, raw materials and materials, the inclusion of Azerbaijani businesses in global competition;

$>$ creation of conditions for Azerbaijani entrepreneurs to access world markets with the provision of organizational, financial and information support by the state;

$>$ protection of national and foreign economic interests, protection of the domestic market;

$>$ Establishment and maintenance of a favorable international regime in relations with various states and international organizations.

Azerbaijan is perceived as a country with constant reforms and adequate to the changing economic environment. In particular, in order to develop entrepreneurship in the country, to improve the quality of the business environment and economic conditions, to adapt the legislative framework to the requirements of the time, to study and apply national and foreign capital investments, modern technological tools, management practices, as well as high quality. as well as the production of competitive goods and services is one of the priorities of the economic development strategy defined by the country's leadership [14].

As we have noted, the main economic goal of Azerbaijan in recent years is to increase the competitiveness of the national economy by increasing the economic activity of businesses and ensure the sustainability of the dynamic development achieved in the country through the effective integration of the non-oil sector and entrepreneurship.

Entrepreneurship development Along with the creation of a fertile economic environment in the country, it is important to systematically implement state support in the organization of foreign economic relations. The development of foreign economic relations of entrepreneurs depends on the improvement of the system of state regulation of entrepreneurship. Significant work has been done in this direction in recent years. Working mechanisms have been formed to protect the rights of entrepreneurs, and as a result of their implementation, the number of cases of interference has significantly decreased. Regular measures are being taken to 
strengthen the information and consulting provision of entrepreneurship and to develop business relations.

At the same time, a mechanism of state financial support for entrepreneurship has been established, and this source is now a real source of meeting the financial needs of small and medium-sized businesses. Within the framework of comprehensive economic reforms implemented in Azerbaijan recently, a lot of important work is being done to realize the export potential of business entities and realize possible opportunities. The introduction of a single online export application in Azerbaijan for the first time in the world is an indicator of the implemented reforms. It should be noted that the representatives of business entities have the opportunity to export goods more easily by filling out a single export application online.

The Single Export Application ensures that representatives of business entities receive all the documents required for the exported goods online in a single window. For the first time in the world, such a step is offered in Azerbaijan, and the relevant service is provided through the Digital Trade Hub and the Azexport portal. Representatives of business entities will be able to export their goods more easily by filling out the Single Export Application online, as well as reduce the time spent on export operations and minimize the amount of money spent. During the implementation of the reform policy, the formation of a fertile economic environment for the implementation of export activities of representatives of business entities in Azerbaijan was accompanied by numerous incentives. Among the measures taken is the establishment of the Internet portal Azexport.az, the Digital Trade Hub and the One-Stop Export Support Center, as well as the launch of operations $[15,17]$.

The purpose of introducing the possibility of filling out a single export application electronically is to facilitate the work and export procedures of export representatives engaged in small and medium enterprises, to minimize the contact of officials and entrepreneurs in the process of activity. Offering this type of service will also greatly facilitate the issuance of permits for businesses located in different regions of Azerbaijan. It should be noted that the achievement of the above-mentioned process, the system of support for the export activities of business entities and the regulation of their foreign economic relations in general has been the result of long-term purposeful activities. Thus, the legal and regulatory documents adopted in the field of entrepreneurship development, further improvement of the state financial mechanism for entrepreneurship have increased the self-confidence of business people, stimulated the expansion of entrepreneurial activity, especially the launch of new businesses in the regions. are actively joining.

In addition, the Law of the Republic of Azerbaijan on State Assistance to Small Entrepreneurship is actively used in the regulation of issues related to business entities in the relevant field [14]. This law also reflects the economic methods of regulation. As we know, economic methods are considered more advanced. If we look at the directions of state support for small business, we can see that the issues from the establishment of business entities to the regulation of their foreign economic activity were considered in detail. Let's look at those directions:

$>$ stimulation of small business and creation of development-related infrastructure;

$>$ development and implementation of measures to support small business;

$>$ organization of preferential conditions for small business entities to obtain financial, information, material and scientific-technical resources;

$>$ providing support to small businesses in connection with the creation of qualified human resources, professional development and retraining; 
assistance to economic-foreign, activity of small business entities, as well as development of financial-credit, production, scientific-technical, information and trade relations with foreign counterparts;

$>$ introduction of a simplified system of state registration (accounting), submission of accounting and statistical reports, licensing of their activities and certification of their products (services, works) for small business entities;

$>$ carrying out research related to the development of small business.

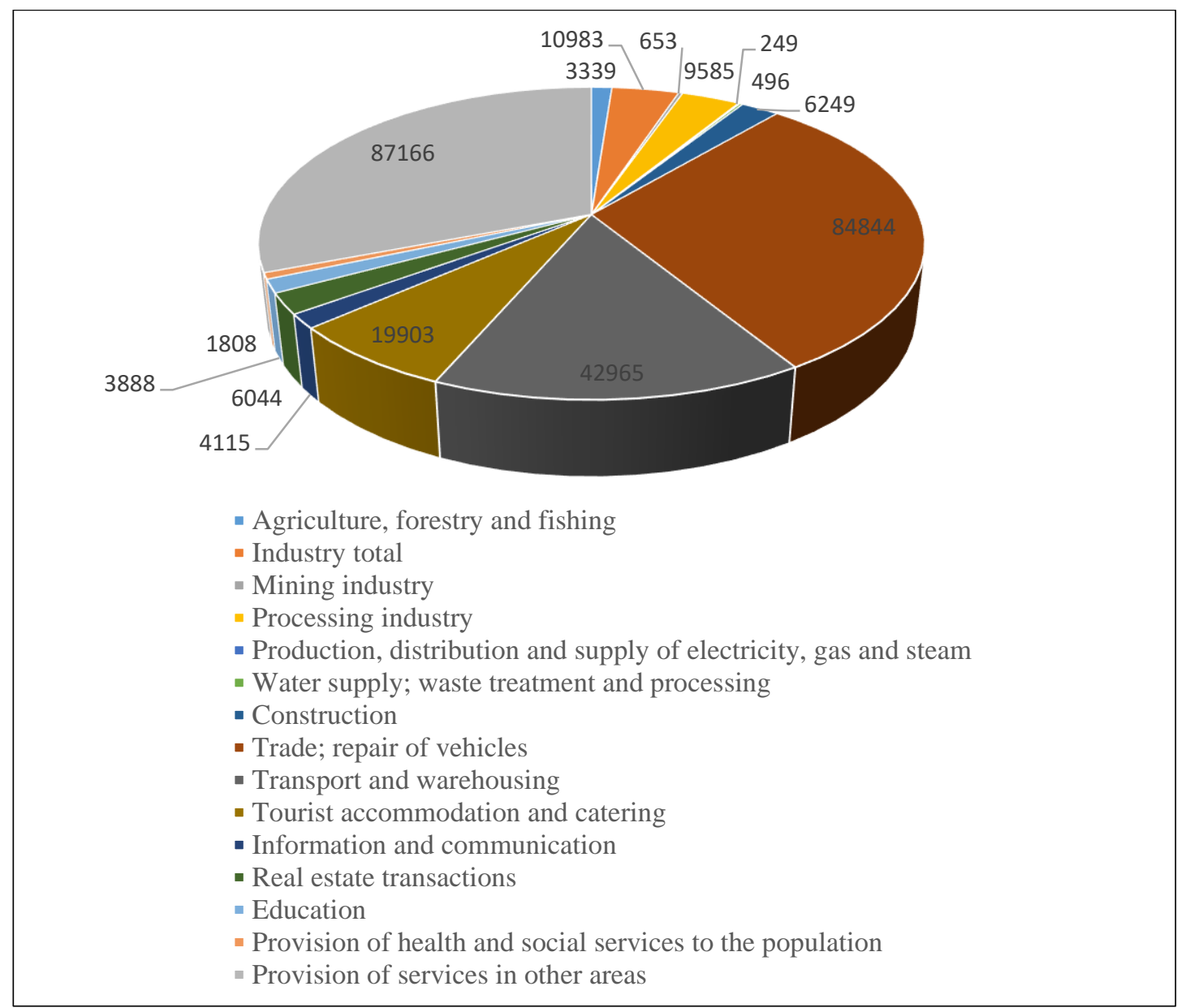

Fig 3: Number of micro-, small and medium business entities operating by economic activity and types of property (Source: Mekhraliyeva A.A. ESD 2021).

The Strategic Roadmap identifies key extents for economic restructuring and progress in SMEs in the short, medium and long period. This study includes a strategic vision for 2020, a long-term vision for the period up to 2025, and a target for the period after 2025. The Strategic Roadmap summaries not only the strategic goals and objects for the pertinent period, but also the priorities set for attaining the goal lines set for those years and the measures to be applied within those priorities. the name of the event, main and other executors, outcome indicators and specific implementation period are reflected $[2,16]$. 
Effective implementation of these priorities in the short term will form the basis of the next steps to be implemented in the medium and long term, thus ensuring the efficiency of the implementation process. The implementation of the Strategic Roadmap will be ensured through communication and cooperation with non-governmental organizations, local and international private sector partners. In order to achieve the strategic goals, set out in the Strategic Roadmap for the development of SMEs in the country and to ensure maximum use of relevant opportunities, the following have been identified as strategic goals:

$>$ Further improvement of the business environment and regulatory framework in the country in order to increase the impact of SMEs on Azerbaijan's GDP in the long run;

$>$ Ensuring efficient and effective access to financing resources in order to create a sustainable network of SMEs;

$>$ Internationalization of SME activities and increasing access to foreign markets in order to increase the country's foreign exchange reserves and ensure compliance of goods produced in the country with international standards [3,4].

Conclusion: The exchange rate of the national currency - manat - plays an important role in the formation of export potential. The high exchange rate of the national currency in relation to world convertible currencies, as a rule, negatively affects the use of the country's export potential, making imports more profitable. Whereas in conditions of a cheaper exchange rate of the national currency in relation to the dollar, euro, etc., it is profitable to export. Some countries, when determining the exchange rate of the national currency, adhere to its cheapness in relation to other currencies in order to intensify export activities. For the formation of successful foreign economic activity within the country, it is important to achieve sustainable development of the private sector, creating favorable conditions for entrepreneurship, both small and large. The formation of the optimal ratio of the state and non-state sectors of the economy, the oil and non-oil sectors, the production and non-production spheres is of great importance. In the manufacturing sector, it is necessary to increase the share of manufacturing industries, to support innovative production. This also applies to the oil sector, where you can switch to the production of various petroleum products, the development of the petrochemical industry, etc. With regard to agriculture, it is necessary to create and maintain agro-industrial complexes that produce various goods based on agricultural raw materials. Regarding the nonmanufacturing sector, it should be noted that it is desirable that a significant place in this area be occupied by scientific institutions, consulting companies. That is, it is assumed a shift from simple services, trade, obits to more complex ones that meet modern requirements, for example, scientific services, business consulting, etc. and entering foreign markets with these services. The above measures will reduce dependence on oil exports, ensuring relatively balanced economic growth [18].

Investigation of the structure and potential export opportunities in the Republic of Azerbaijan can be divided into the following directions, in which its development is advisable:

$>$ develop sectors of the non-oil sector, producing goods that are competitive on the world market;

$>$ support for the development of the agro-industrial complex in the country as an important export industry. This area includes effective specialization in economic regions, the transition to intensive growth, the use of new technologies, the creation of large agricultural firms;

$>$ diversification of the manufacturing industry, the development of such industries as oil engineering, chemical, textile industries, ferrous and non-ferrous metallurgy; 
$>$ development of tourism;

$>$ development of high-tech services in the field of information technology;

$>$ incentives for entrepreneurs producing competitive goods to enter the foreign market;

$>$ the creation of free economic zones in border areas to increase the activity of the country's regions and their involvement in export operations.

$>$ implementation of measures of foreign exchange, fiscal and monetary policies that stimulate exports.

\section{REFERENCES}

1. CESD, "Small and Medium Entrepreneurship in Azerbaijan; Country Assessment", 2012, www.cesd.az;

2. Mekhraliyeva A.A. "Fundamental directions of state support for export activities of small and medium-sized entrepreneurship in Azerbaijan", ESD 2021, 10 p.;

3. Decree of the President of the Republic of Azerbaijan on further improvement of management in the field of small and medium business, Baku - 2017.

4. Economic Reform Analysis and Communication Center http://iqtisadiislahat.org/ (date accessed: 08/06/2021).

5. Ed. Bulatova A.S. and Liventseva N.N. (2010), World Economy and Foreign Economic Activity. M - 2010, 654 p.

6. Entrepreneurship Development Fund of the Ministry of Economy of the Republic of Azerbaijan http://edf.gov.az/ (date accessed: 08/06/2021);

7. Law of the Republic of Azerbaijan on Entrepreneurship, Baku - 1992.

8. Law of the Republic of Azerbaijan on state support for small business;

9. Official website of the President of the Republic of Azerbaijan (date accessed: 08/06/2021);

10. Official website of the State Statistics Committee (date accessed: 08/06/2021);

11. Regulation on the adoption of "Rules for the determination of large, medium and small entrepreneurship" Decision of the Cabinet of Ministers of 5 June 2015;

12. Regulation on the adoption of "Rules for the determination of large, medium and small entrepreneurship" Decision of the Cabinet of Ministers of 5 June 2015;

13. Small and Medium-Sized Business: Foreign Development Experience // Young Scientist. - 2012. - №4. - p. 177-181;

14. State Customs Committee of the Republic of Azerbaijan https://customs.gov.az/az (date accessed: 08/06/2021).

15. Strategic Road Map on Production of Consumer Goods at Small and Medium Enterprises in the Republic of Azerbaijan 2016;

16. Strategic Roadmap for Financial Services Development in the Republic of Azerbaijan. December 6, 2016;

17. Strategic Roadmap for the Development of Logistics and Trade in the Republic of Azerbaijan", Baku - 2016;

18. Strategic Roadmap for the production of consumer goods at the level of small and medium enterprises in the Republic of Azerbaijan, Baku - 2016. 


\title{
MONEY MARKET AND ITS INSTRUMENTS (ON THE EXAMPLE OF GEORGIA)
}

\author{
${ }^{1}$ Kapanadze Maia, ${ }^{2}$ Nozadze Mzevinar \\ ${ }^{1,2}$ Faculty of Business Technology, Georgian Technical University, PhD in Economics, Associate Professor, \\ E-mail: ${ }^{1}$ kapinio@yahoo.com, ${ }^{2}$ mzia_nozadze@yahoo.com
}

\begin{abstract}
The money market is an organic part of the financial market. The money market facilitates the trading of money and short-term securities and hence the flow of cash from lenders to money borrowers. It is through the money market that cash flow is possible between the following market participants: central banks, commercial banks, insurance companies, mutual funds, private pension funds, as well as individuals.

The Georgian money market is an integral part of the international money market, where the following main money market instruments are in circulation: currency futures, treasury bonds, treasury bonds, repo transactions.
\end{abstract}

Keywords: Money market, Money market instruments, Foreign exchange market, Foreign exchange market instruments, Central bank.

We consider it correct to divide the money market as an integral part of the financial market into the following components:

1. The market for short-term securities, where the object of buying and selling is short-term securities, mainly Treasury bonds and Treasury bonds.

2. Interbank credit market, where the central bank acts as the main lender and trades credit resources between commercial banks and the central bank.

3. The foreign exchange market is where currency is traded based on supply and demand. The main operations in the foreign exchange market are known: spot, swap and forward.

The Georgian money market is regulated by the National Bank. An integral part of the Georgian money market is the interbank foreign exchange market, organized in the Bloomberg International Electronic Trading System, through which foreign exchange transactions are concluded. The interbank deposit / loan market is a money market where banks trade shortterm excess liquidity. "This market is of great interest to the National Bank of Georgia, as this market plays a decisive role in the functioning of the money transfer mechanism. The National Bank of Georgia influences interest rates by announcing its monetary policy and using monetary policy instruments " [1].

The auction of the National Bank of Georgia is an instrument of monetary policy. "The purpose of the currency auction is to replenish international foreign exchange reserves, eliminate the influence of the exchange rate on temporary excess inflows, etc" [2].

It is important to note that the National Bank of Georgia officially recognizes the principles of the Global Foreign Exchange Market Code in international practice and acts in accordance with these principles. It is known that short-term government securities are traded on the Georgian money market. The government securities market has been stable since 2009. They are issued on a regular basis, in accordance with the schedule agreed with the National Bank, which is provided to market participants on a quarterly basis. 
Currently, the Ministry of Finance issues securities with maturities ranging from 1 to 10 years. It is known that individuals and legal entities cannot purchase these securities directly from the central bank; commercial banks play the role of intermediaries in this transaction. Foreign investors also participate in transactions with securities, although their share has decreased compared to 2011-2012.

Given the fact that there is a demand for this type of securities from non-residents, nonresidents can buy and hold them through the global network of securities. At this stage, three such cash registers (Statestreet, City, Deuche Bank) serve the Georgian market, and in early 2016, the international central depository Clearstream was added to them. The National Bank has introduced a modern government securities infrastructure that meets the highest standards and is an interesting example for other countries. The updated Georgian Securities Settlement System (CSSS) has been operating in Georgia since 2018. This system is available to all market participants - local and international, and all types of securities can be traded and settled.

Taking into account repo transactions in international practice, the interbank interbank repo market was created jointly by the National Bank of Georgia and commercial banks. From April 2020, the National Bank began currency swap operations to support additional liquidity in the banking sector. This tool is available not only to commercial banks, but also to microfinance organizations. "In the case of currency swaps, a limit swap of US \$ 200-200 million (total 400 million) is available for commercial banks and microfinance organizations. The total amount of the swap is distributed among the participants in the scheme in proportion to the market share of the financial institution"[3]. In addition, to avoid excessive concentration, a limit of up to $25 \%$ of the total was set for one organization, which increased the availability of resources for small financial institutions.

It is important to note that "IFC, a member of the World Bank Group, supported the National Bank of Georgia in issuing Eurobonds in national currency, which is practically the first precedent in terms of international placement of government securities in the Georgian financial sector. and the banking system "[4].

As for the circulation of currency derivatives - currency swaps, currency forwards and currency futures, the movement of capital in the currency market of Georgia is insignificant. "Forward Currency Agreement means the delivery of an appropriate amount of currency at a pre-agreed time at a pre-agreed exchange rate. The exchange rate is agreed upon at the time of the conclusion of the contract, and the currency is delivered upon expiration" [5] The demand for foreign exchange forward contracts has grown relatively recently, as demand for foreign exchange hedging instruments has increased amid increased volatility in the exchange rate.

Government securities are issued in national currency in an intangible form. The nominal value of one government security is 1,000 lari. Government securities are sold at auction. The auction is held on the days of the auction, announced in advance by the National Bank of Georgia. Securities can be owned by both legal entities and individuals, residents and nonresidents.

\section{CONCLUSION}

The issue, circulation, accounting and redemption of treasury bonds and treasury bonds by the Ministry of Finance of Georgia shall be regulated by the relevant normative acts.

Usually government securities are characterized by minimal risk and high liquidity. Treasury securities serve the development of financial markets. Even in a developed money market, the country's economic growth potential and the effectiveness of monetary policy are increasing. 


\section{REFERENCES}

1. Monetary market. https://www.nbg.gov.ge/index.php?m=544

2. Kovzanadze I., Kontridze G., Banking: Theory and Practice, Sezani Publishing, Tbilisi, 2014.

3. National Bank of Georgia. Yearly report 2020. Pp -67. https://www.nbg.gov.ge/uploads/publications/annualreport/2021/annual_report_2020_n bg.pdf.

4. Nozadze M. International Monetary, Financial and Credit Relations. Textbook. Dani Publishing, Tbilisi, 2021.

5. Khidesheli M. Theory of International Finance. Akaki Tsereteli State University Publishing House. 2017. PP- 200. 


\title{
АКТУАЛИТЕТЫ НЕЙТРАЛИЗАЦИИ УГРОЗ ЭНЕРГЕТИЧЕСКОЙ БЕЗОПАСНОСТИ УКРАИНЫ
}

\author{
Лиана Птащенко
}

Доктор экономических наук, профессор, Национальный университет «Полтавская политехника имени Юрия Кондратюка» (Украина), ORCID ID: 0000-0002-4228-0421, Email: lianaptaschenko63@ meta.ua

\section{PЕЗЮМЕ}

Обосновывается необходимость нейтрализации угроз энергетической безопасности Украины, чтобы национальная энергетика страны смогла перейти на мировые требования и стандарты, достойно соответствовать этим тенденциям. Для этого необходима трансформация энергетического сектора с дотационного и проблемного для национальной экономики, в конкурентный и гибкий, развитие которого основывается на внедрении инновационных разработок в области добычи, переработки, производства, трансформации, поставки и потребления топливно-энергетических ресурсов.

Автор считает, что в нынешних условиях хозяйствования сложно конкретизировать и прийти к единой трактовке понятия энергетической безопасности, поскольку состояния национальных энергетических систем находятся в динамизме; являются нестабильными соотношение основных энергетических ресурсов и их роли в развитии национальных экономических систем, уровень их доступности, экологические последствия их использования, социальные вызовы относительно мировых ценовых колебаний.

Предлагается рассматривать энергетическую безопасность как способность устойчивого конкурентного функционирования энергетических систем различного уровня (глобального, национального, регионального), адекватность реагирования государством, бизнесом и населением на технологические, экономические и социальные вызовы, что требует создания условий для диверсификации источников и путей поставок энергоресурсов с учетом уровня научно-технического развития энергетического рынка и экологической безопасности.

Подчеркивается, что при решении проблем энергетической безопасности и формирования национальной политики ее обеспечения Украина должна учитывать международные принципы и тенденции. Отмечены положительные аспекты в этом направлении. Так, НАК «Нафтогаз Украины» разработала новую программу добычи природного газа под названием «Тризуб», принято Закон Украины «Об обеспечении прозрачности в добывающих отраслях», активизировалась работа по реализации Концепции развития газодобывающей отрасли. Ликвидировав апробацию геоинформации для нефтегазовых площадей, начались мероприятия по проведению онлайн-аукционов на платформе Prozzoro. Необходимо использовать научные разработки по прогнозированию поставок газа имеющимися газотранспортными системами на основе расчетов минимально возможного объема транзитного газа для обеспечения прибыльности его транспортировки. Это позволит учесть наиболее оптимальные способы обеспечения транспортировки природного газа в Европу по территории Украины и адекватно оценить возможности реверсных поставок газа.

При формировании или усовершенствовании Энергетической стратегии Украины необходимо стремиться к сбалансированности основных ее направлений с учетом Мировой энергетической трилеммы: безопасность, доступность, экологическая устойчивость. 
Ключевые слова: энергетическая безопасность, энергетический рынок, угрозы энергетической безопасности, национальная энергетика, топливно-энергетические ресурсы, природный газ, энергетическая трилемма, инновации.

Постановка проблемы: На мировом энергетическом рынке в последние годы происходят быстрые и глобальные изменения. Они заключаются в доминировании крупных производителей, ликвидации неэффективных сетей, соблюдении правил экономической конкуренции на энергетических рынках, формировании такой среды, которая обеспечивала бы равные возможности для развития всех видов производства энергии, источников и маршрутов поставок топливно-энергетических ресурсов, активной инвестиционной и правовой поддержки развития рынка альтернативной энергетики. Характерными признаками этой модели является преимущественное использование низкоуглеродистых источников и технологий с высокими коэффициентами преобразования энергии; введение интеллектуальных систем (smart energy), реализация мер по предотвращению и адаптации к изменению климата в рамках Парижского соглашения.

Изложение основного материала исследования: Чтобы перейти на мировые требования и стандарты, достойно соответствовать этим тенденциям, национальная энергетика Украины должна быть трансформирована с дотационной и проблемной для экономики, в конкурентный и гибкий сектор национального хозяйства. Следует реализовать новые возможности для поиска и внедрения инновационных разработок в области добычи, переработки, производства, трансформации, поставки и потребления топливно-энергетических ресурсов.

Указанная трансформация невозможна без нейтрализации угроз энергетической безопасности Украины, которые обобщены на рисунке 1.

Все эти угрозы обусловливают потребность в более четком планировании и координации деятельности органов государственной власти, которую необходимо направить на:

- успешное завершение реформирования энергетических рынков;

- интеграцию энергетического сектора Украины в энергетические рынки ЕС и системы европейской энергетической безопасности;

- повышение энергетической эффективности;

- преодоление зависимости от российского энергетического рынка;

- создание условий для надежного энергообеспечения и транзита энергоресурсов;

- повышение устойчивости энергетической отрасли к негативным внешним воздействиям;

- формирование общенациональной парадигмы энерго- ресурсо- сбережения и эффективности. 


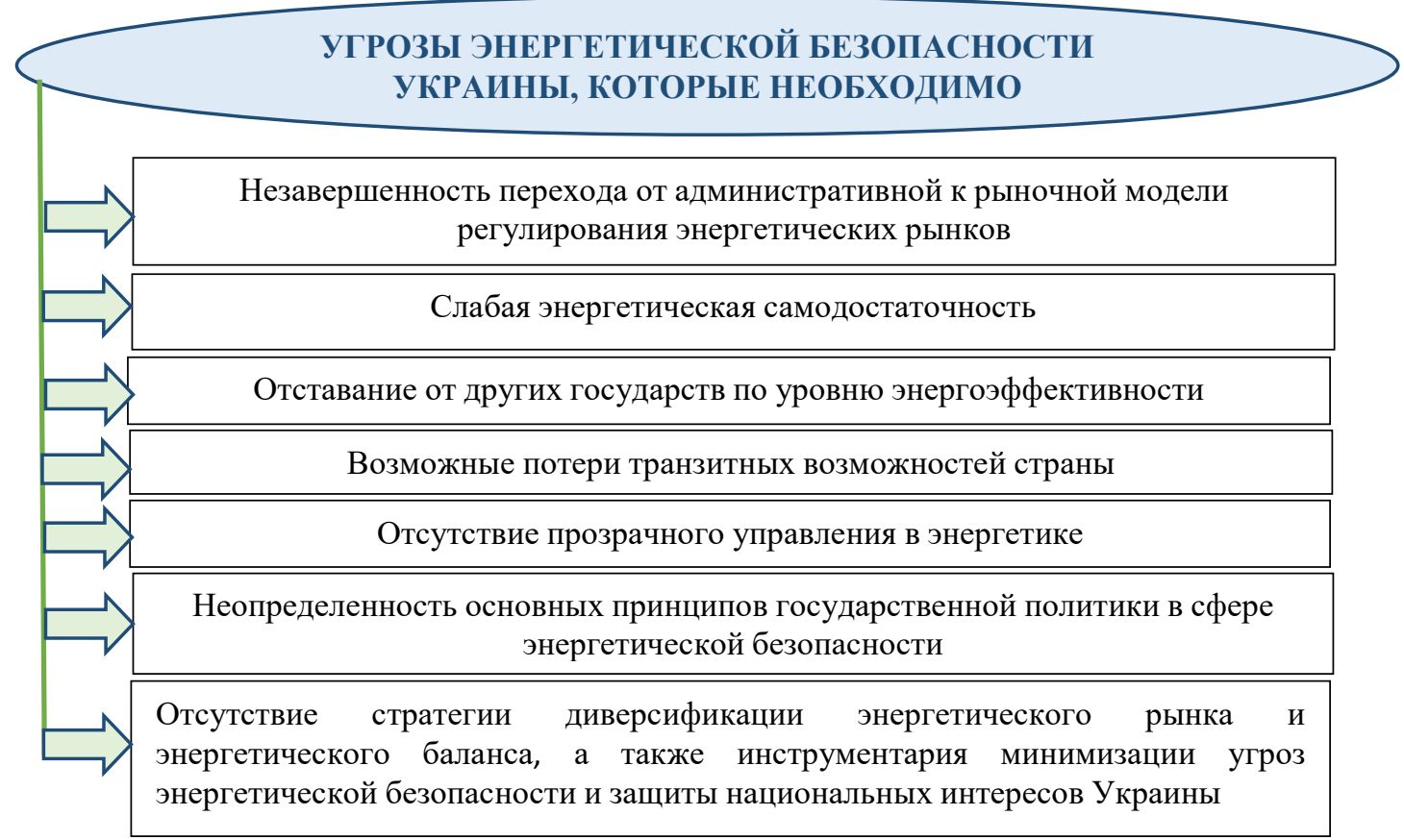

Рис. 1. Основные угрозы энергетической безопасности Украины

Стоит отметить, что в системе национальной безопасности главная роль принадлежит экономической и энергетической составляющим. Экономическая безопасность требует наличия в государстве достаточных ресурсов для реализации воспроизводственных процессов во всех сферах бизнеса и деятельности человека, обеспечения стабильности развития и независимости государства относительно возможностей самостоятельно формировать и осуществлять внутреннюю и внешнюю политику.

Сегодня сложилась ситуация, когда «двигателем» развития экономики любого государства является энергетика. Вместе с тем достаточно сложно четко сформировать понятие энергетической безопасности, поскольку состояния национальных энергетических систем находятся в динамизме; являются нестабильными соотношение основных энергетических ресурсов и их роли в развитии национальных экономических систем, уровень их доступности, экологические последствия их использования, социальные вызовы относительно мировых ценовых колебаний.

На наш взгляд, актуальным определением энергетической безопасности является способность к устойчивому конкурентному функционированию энергетических систем различного уровня (глобального, национального, регионального), адекватность реагирования государством, бизнесом и населением на технологические, экономические и социальные вызовы, что требует создания условий для диверсификации источников и путей поставок энергоресуров, их доступности, с учетом уровня научно-технического развития энергетического рынка и экологической безопасности.

Чтобы соответствовать мировому уровню развития экономических отношений на энергетическом рынке в 2017 году была одобрена Энергетическая стратегия Украины до 2035 года. Это ставит перед Украиной новые экономические и технологические вызовы, обусловленные:

- доминированием политического фактора в формировании и реализации энергетической политики; 
- быстрыми изменениями структуры, источников и маршрутов поставок первичных энергетических ресурсов, потерей общепринятого статуса их экспортерами и транзитерами;

- преимущественным использованием низкоуглеродистых источников и технологий с высокими коэффициентами преобразования энергии;

- сокращением энергетической нагрузки на национальные ВВП и быстрым ростом энергоэффективности производств;

- реорганизацией, разукрупнением энергетики, появлением «профессиональных потребителей», которые принимают активное участие в процессе производства энергетических продуктов, потребляемых ими же;

- интегрированием национальных энергетических рынков по общим межгосударственными (региональными) стандартами;

- повышением уровня управления энергетическими сетями и системами, повышением требований к системам обеспечения кибернетической и физической безопасности энергетических объектов;

- диджитализацией энергетики, внедрением интеллектуальных энергетических сетей (smart energy) - реализацией мер по адаптации к изменениям климата в рамках Парижского соглашения [1,2].

Как отмечалось, одной из определяющих угроз, возникших в последнее время, является незавершенность перехода от административной к рыночной модели регулирования энергетических рынков. Ее заметным проявлением является существенное отставание в темпах разработки и принятия нормативно-правовых актов, которые должны быть направлены на полноценную имплементацию положений недавно принятых законов Украины относительно функционирования энергетических рынков и перехода субъектов хозяйствования на лучшие мировые бизнеспрактики, основанные на стратегиях непрерывности и прозрачности бизнеса, механизмах экономической конкуренции, корпоративной культуры.

Решение проблем энергетической безопасности и формирования национальной политики ее обеспечения в Украине не может не учитывать международные аспекты этого вопроса.

Мировой опыт свидетельствует о том, что страны разрабатывают энергетическую политику в зависимости от своих внутренних условий, обусловленных различными природными ресурсами, географическим положением, социально-экономическими системами. При этом, мировое сообщество требует учитывать экологический аспект, как важную составляющую энергетической трилеммы.

Индекс Мировой энергетической Трилеммы может помочь странам и заинтересованным сторонам определить, какие области энергетической политики необходимо улучшить, а также на примерах других стран помочь определить наиболее подходящие варианты.

Под энергетической трилеммой принято понимать необходимость поддерживать баланс между тремя основными характеристиками энергетической системы - безопасностью, доступностью и экологической устойчивостью.

Мировой энергетический совет разработал концепцию «Энергетическая трилемма», которая позволила принять обоснованные решения по сбалансированию энергетической безопасности, распределению энергетических ресурсов и экологичности [3]. Стоит отметить, что, формируя рейтинг эффективности энергетической политики стран, энергетические балансы были оценены по мировому индексу энергетической трилеммы. Согласно официальному отчету за 2019, девять из 10 стран-лидеров рейтинга были 
страны ЕС (Швейцария, Швеция, Дания, Великобритания, Финляндия, Франция, Австрия, Люксембург, Новая Зеландия), что свидетельствует об эффективности сбалансированной энергетической политики ЕС: развитие единой энергетической инфраструктуры в ЕС (Договор о Европейском Союзе, Маастрихт), внедрение Директив ЕС в 2012/27 / ЕС «Энергоэффективность» и 2014/94 / ЕС «О развитии инфраструктуры альтернативного топлива», рекомендации Европейской Комиссии 2012/148 / ЕС «Подготовка к внедрению систем интеллектуального учета», Стратегическая энергетическая технология, Климатическая политика «Зеленое соглашение» и другие [4]. Таким образом, Европейский вектор развития национальной экономики Украины требует адекватной сбалансированности государственной политики по обеспечению энергоэффективности.

Мировой энергетический совет предлагает такие ключевые инструменты эффективной национальной энергетической политики:

- осуществление ежегодного мониторинга (World Energy Issues Monito), расчеты мирового индекса энергетической трилеммы (World Energy Trilemma Index), что позволяет оценить страны мира по показателям энергетической безопасности, справедливого доступа к энергии, экологической устойчивости;

- разработка возможных мировых энергетических сценариев оценки динамической устойчивости энергетических систем в условиях усиления влияния различных рисков с учетом имеющихся резервов (общие сети, политика, запасы);

- информационное обеспечение и оценка вероятных рисков, скорость реагирования;

- адаптивная гибкость, способность к инновациям в привлечении новых ресурсов, бизнес-моделей, технологий, политики и социальных инноваций [3].

Важное место в обеспечении энергетической безопасности принадлежит активизации внутренней добыче энергоресурсов. В этом вопросе в Украине много проблем. Не смотря на достаточное для потребления на внутреннем рынке количество залежей энергоресурсов, объемы добычи нефти и газа крайне недостаточные. Это подтверждают статистические данные. К примеру объемы валовой добычи природного газа на протяжении 5 лет практически не увеличиваются (табл. 1).

Таблица 1. Валовая добыча природного газа в Украине в 2015-2020 годах, млрд м

\begin{tabular}{|l|c|c|c|c|c|c|}
\hline & $\mathbf{2 0 1 5}$ & $\mathbf{2 0 1 6}$ & $\mathbf{2 0 1 7}$ & $\mathbf{2 0 1 8}$ & $\mathbf{2 0 1 9}$ & $\mathbf{2 0 2 0}$ \\
\hline Частные предприятия & 3,9 & 4,2 & 4,1 & 4,4 & 4,6 & 4,34 \\
\hline ГАО «Чорноморнефтегаз» & 0,01 & 0,01 & 0,01 & 0,01 & 0,01 & 0,01 \\
\hline ПАО «Укрнафта» & 1,5 & 1,3 & 1,1 & 1,1 & 1,2 & 1,16 \\
\hline АО «Укргазвидобування» & 14,5 & 14,6 & 15,3 & 15,5 & 14,9 & 14,23 \\
\hline Вместе & 19,9 & 20,1 & 20,5 & 21,0 & 20,7 & 19,74 \\
\hline
\end{tabular}

Динамика свидетельствует о снижении валовой добычи природного газа в Украине за последние 3 года (рис. 2) [5]:

Но есть и ряд положительных сдвигов в этом направлении. НАК «Нафтогаз Украины» разработала новую программу добычи природного газа под названием «Тризуб».

Прорыв планируется осуществить на трех перспективных направлениях: добраться до сланцевого газа, открыть на большой глубине суши вторую «уникальную» Шебелинку, овладеть месторождением шельфа Черного моря - участком «Дельфин». Кроме того, принят Закон Украины «Об обеспечении прозрачности в добывающих отраслях». 


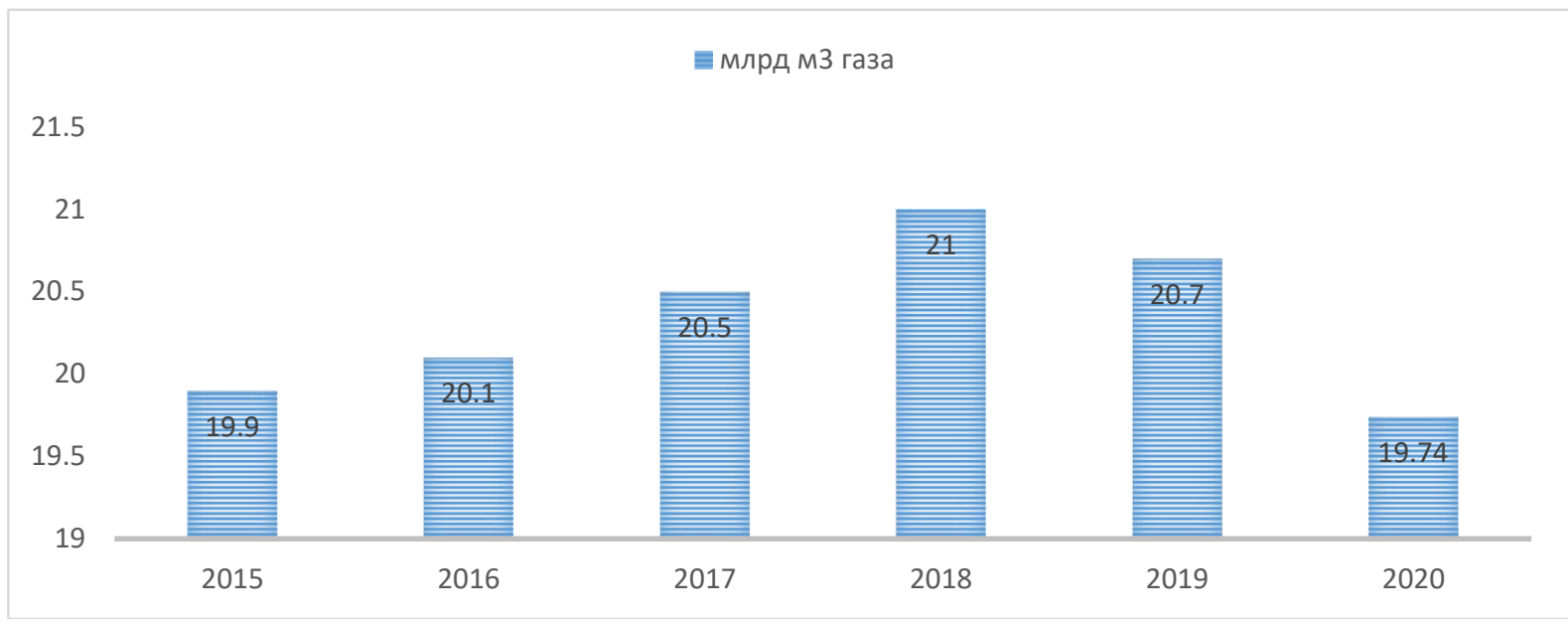

Рис. 2. Динамика добычи природного газа в Украине

Документ вводит обязательность международных стандартов отчетности для добывающих отраслей и обеспечивает транспарентные правила в индустрии. Специалисты подчеркивают, что эти меры должны увеличить инвестиционную привлекательность сектора на 4\%.

Кроме того, активизировалась работа по реализации Концепции развития газодобывающей отрасли Украины, что предусматривает: проведение аукционов и конкурсов PSA, реформу Госгеослужбы, усовершенствование Закона Украины «О нефти и газе» и разработку новой версии Кодекса о недрах.

Реализация заданий по повышению собственной добычи природного газа требует значительного увеличения инвестиций в газодобывающую отрасль, в частности путем привлечения финансовых ресурсов предприятий отрасли, иностранных инвесторов и международных финансовых институтов, а также кредитных ресурсов и средств других источников, не запрещенных законодательством.

Учитывая изложенное, в Украине нужно определить оптимальный портфель вариантов в условиях политической, технологической и экономической неопределенности. Очень актуальным и необходимым вопросом является определение временного горизонта, поскольку некоторые из вариантов диверсификации могут быть реализованы быстро, в то время как имплементация других вариантов реально потребует значительного времени.

Ликвидировав апробацию геоинформации для нефтегазовых площадей, мероприятия по проведению онлайн-аукционов на платформе Prozzoro для продаж и проведения международных конкурсов по заключению соглашений. Проведение аукционов и конкурсов определено как приоритет новой пятилетней стратегии Европейского банка реконструкции и развития в Украине, а также эти правила зафиксированы в меморандуме с Международным валютным фондом.

Имплементация международных стандартов отчетности и повышение прозрачности деятельности предприятий является значительным прогрессом в развитии нефтегазодобывающей промышленности. 
Выводы: Таким образом, обновление законодательства в сфере энергетической политики Украины должно способствовать ускорению развития газодобывающей отрасли. В частности, в фокусе внимания должно быть создание благоприятных условий для внедрения современных технологий и разработки углеводородных ресурсов Черного и Азовского морей ввиду большого количества запасов. Реализация новых национальных инфраструктурных проектов может осуществляться на принципах государственно-частного партнерства. Отдельного внимания требует и добыча нетрадиционных углеводородов, поскольку значительная часть газовых запасов и ресурсов труднодобываемые и сосредоточены в плотных коллекторах.

Следует также взять во внимание научные разработки по прогнозированию поставок газа через имеющиеся газотранспортные системы на основе расчетов минимально возможного объема транзитного газа для обеспечения прибыльности его транспортировки, что позволит учесть наиболее оптимальные способы обеспечения непрерывной поставки природного газа в Европу по территории Украины и дать оценку реальным возможностям реверсных поставок газа.

При формировании или усовершенствовании Энергетической стратегии Украины необходимо сбалансировать основные ее направления с учетом Мировой энергетической трилеммы: безопасность, доступность, экологическая устойчивость.

\section{ЛИТЕРАТУРА}

1. On approval of the Energy Strategy of Ukraine for the period up to 2035. URL: https://zakon.rada.gov.ua

2. On ratification of the Paris Agreement: Law of Ukraine of July 14, 2016 № 1469-VIII. URL: http://zakon5.rada.gov.ua/laws/show/1469-19.

3. World Energy Council. URL: https://www.worldenergy.org

4. Improving energy efficiency. EU legislation. URL: http://zvt.abok.ru/articles/80/Povishenie_energoeffektivnosti_Zakonodatelstvo_ES

5. Gas production in Ukraine. URL: https://www.minprom.ua/news/269186.html

\section{ACTUALITIES FOR THE NEUTRALIZATION OF THREATS TO ENERGY SECURITY OF UKRAINE}

\section{Liana Ptashchenko}

Doctor of Economics, professor, National University «Yuri Kondratyuk Poltava Polytechnic» Email: lianaptaschenko63@ meta.ua; ORCID ID: 0000-0002-4228-0421

\section{ANNOTATION}

The necessity of neutralizing threats to the energy security of Ukraine is substantiated so that the national energy sector of the country could switch to world requirements and standards and adequately correspond to these trends. This requires the transformation of the energy sector from a subsidized and problematic one for the national economy, into a competitive and flexible one, the development of which is based on the introduction of innovative 
developments in the field of extraction, processing, production, transformation, supply and consumption of fuel and energy resources.

The author believes that in the current economic conditions it is difficult to concretize and come to a unified interpretation of the concept of energy security, since the states of national energy systems are in dynamism; the ratio of the main energy resources and their role in the development of national economic systems, the level of their availability, the environmental consequences of their use, social challenges in relation to world price fluctuations are unstable. It is proposed to consider energy security as the ability of sustainable competitive functioning of energy systems of various levels (global, national, regional), the adequacy of the state, business and population's response to technological, economic and social challenges, which requires the creation of conditions for diversification of sources and routes of energy supply, taking into account the level scientific and technical development of the energy market.

It is emphasized that when solving problems of energy security and forming a national policy for its provision, Ukraine should take into account international principles and trends. Positive aspects in this direction are noted. Thus, NJSC Naftogaz of Ukraine has developed a new natural gas production program called Trident, the Law of Ukraine "On Ensuring Transparency in the Extractive Industries" has been adopted, and work has been intensified to implement the Concept for the Development of the Gas Production Industry. Having liquidated the approbation of geoinformation for oil and gas fields, preparatory measures have begun for conducting online auctions on the Prozzoro platform. It is necessary to use scientific developments in predicting gas supplies by the existing gas transmission systems based on calculations of the minimum possible volume of transit gas to ensure the profitability of its transportation. This will allow taking into account the most optimal ways to ensure the transportation of natural gas to Europe through the territory of Ukraine and adequately assess the possibilities of reverse gas supplies.

When forming or improving the Energy Strategy of Ukraine, it is necessary to strive to balance its main directions, taking into account the World energy trilemma: safety, accessibility, environmental sustainability.

Keywords: energy security, energy market, threats to energy security, national energy, fuel and energy resources, natural gas, energetic trilemma, innovation. 


\title{
CORRELATION OF OIL AND GAS RESOURCES OF THE CASPIAN COUNTRIES
}

\author{
Gulshan Zeynalova \\ $\mathrm{PhD}$ of history of the Institute of History of the National Academy of Sciences of Azerbaijan. \\ Email: gulshee@ hotmail.com
}

After the collapse of the USSR, the water area of this region is a zone of interest for many states. [1]

The Caspian region rightfully serves as one of the most significant regions for most countries interested in the mineral resources that the Caspian is rich in. The Caspian Sea has a significant hydrocarbon reserves.

According to the Energy Information Administration (EIA), hydrocarbon resources in the Caspian basin have the following values: oil - 48 billion barrels of oil, natural gas - 292 trillion. cubic feet (found and probable reserves), of which $75 \%$ and $67 \%$, respectively, are produced or may be produced offshore.

The northern part of the Caspian Sea contains most of the oil reserves, while the southern sector of the Caspian Sea is rich in natural gas.[2]

It should be emphasized that the list of states that have the rights to use the resources of the

Caspian Sea is as follows: Azerbaijan, Iran, Kazakhstan, Russia and Turkmenistan.

It is impossible to correlate the importance of the oil and gas resources of the Caspian reservoir for each of the above countries, for the following reasons: Azerbaijan and Turkmenistan are countries for which the hydrocarbon potential of the Caspian is the most important predictor of the formation and development of the economy, while for Kazakhstan, the use of oil and gas resources of the Caspian Sea plays an important, but not the most decisive role, since oil and gas deposits in this country are not limited to the Caspian region, but its economy is developing in other directions. Iran and Russia, however, are interested in influencing the direction of flows of oil and gas raw materials, including their transit through the territory of the countries. [3]

The last years for the Caspian region have become the years of a shift in the development of the oil and gas industry of the Caspian "five", which account for $17.6 \%$ of oil reserves and $46.4 \%$ of gas reserves in terms of global reserves.

It is assumed that on the territory of the Caspian shelf, which belongs to Russia, oil reserves amount to 270 million tons, natural gas reserves - 0.5 trillion cubic meters. $m$ of gas. [4]

Of course, it is worth noting that the potential of the Russian sector of the Caspian Sea is significantly lower than the oil and gas potential of Yamal or Western Siberia, but the development of this region is important for the strategic development of the oil and gas sector, in particular offshore drilling.

Oil production in the Russian sector of the Caspian Sea shelf began in 2010 at the Yuri Korchagin field. At the end of 2012, the first Russian millionth ton of oil was produced at the I. Yuri Korchagin. The oil and gas industry is a promising industry not only in the post-Soviet space, but also in other parts of the world. In fact, this industry is strategically important for the Russian state. This is the basis that ensures the stability of the country, and the basis for the development of its economy. [5]

As regards Russia, it should also be noted that it is the only country that does without attracting a foreign investor to carry out oil and gas production in the Caspian region. In addition, production 
activities, which began in the 1990s by OAO NK LUKOIL, emerged without any foundation, despite the fact that the sector, which belongs to Russia, had relatively small reserves of raw materials. Moreover, other Caspian countries actively resorted to the help of foreign investors, which has become a practice for the oil and gas industry. It is important to note that stateowned companies have practically no influence: the main projects for the exploration, production and transportation of oil and gas are concentrated in the hands of foreign companies.

Turkmenistan has significant reserves of oil and gas, but, unlike Kazakhstan and Azerbaijan, since independence, the republic has not distinguished itself with serious successes in the development of hydrocarbon resources due to a less favorable investment climate.

The instability of the investment climate led to the fact that large international companies operating since the mid-1990s and investing in a number of projects for the development of hydrocarbons, faced with a host of problems, were forced to leave the country, in particular, ExxonMobil and Shell. Currently, small foreign companies operate in Turkmenistan under the PSA, while the flagship projects of Turkmenistan are less significant in volume and less developed than in Kazakhstan and Azerbaijan.

A number of companies, including LUKOIL and Conoco Phillips, are currently negotiating on participation in exploration and development of structures in Turkmenistan.

According to the official Turkmenistan, the total oil reserves are estimated at 20.4 billion tons, while about half is concentrated in the Turkmen sector of the Caspian Sea shelf - 12 billion tons of oil.

Explored oil reserves of Turkmenistan - 1.7 billion tons, confirmed - 70 million tons. According to the EIA, the potential oil reserves in Turkmenistan are about 5 billion tons, and the proven reserves are 0.07-0.23 billion tons. According to BP estimates at the end of 2011, the country's proven reserves amount to 100 million tons. A number of independent experts, according to the magazine "Oil \& Gas Eurasia", estimate the explored oil reserves at 0.5 billion tons (Oil \& Gas Eurasia, No. 5, May 2007).

About 170 hydrocarbon deposits have been discovered on the territory of Turkmenistan, of which only one third is being developed. Of the total resources of the Caspian Sea, 32 licensed blocks have been allocated with resources, according to official estimates, oil - 12 billion tons, gas -6 trillion. $\mathrm{m}^{3}$.

Among the countries of the Caspian region, Azerbaijan is most famous for its traditions of oil and gas production. Since the Middle Ages, you can documentarily trace the extraction of "black gold" in the country. [6]

Since gaining independence in 1991, Azerbaijan began to actively attract foreign investment in the country's oil and gas sector to develop rich oil and gas reserves. Azerbaijan has been working for many years to return to its former positions as the center of the oil industry. The signing of numerous contracts with leading foreign oil and gas companies affected the formation of internal political stability and laid the foundation for the economic development of the state, contributing to Azerbaijan's claims to the place of the country as the leader of the region. Today, hydrocarbon raw materials determine the vector of development of modern Azerbaijan, the main principles of the energy policy of which are meeting the country's needs for energy resources and ensuring the energy security of the state.

Azerbaijan ranks second after Kazakhstan in terms of oil reserves. It is oil that has become the country's main asset and strategic resource.

The country's leadership is actively implementing the oil strategy, the essence of which is to invest revenues from the sale of hydrocarbons in other sectors of the national economy, which 
is carried out through the State Oil Fund of Azerbaijan, an analogue of the Kazakh National Oil Fund.

There are 57 oil and gas fields in Azerbaijan, which are being produced, and 18 of them are offshore. The development of onshore fields has been going on for several decades and to a large extent they have already been depleted, therefore the further development of the industry is aimed at the development and development of the deep-sea shelf, where significant volumes of reserves are concentrated and from where most of the production comes.

The largest offshore field is the Azeri-Chirag-Guneshli (ACG) oil field, the reserves of which are approximately $0,9-1,0$ billion tons. It is with the ACG field that Azerbaijan's plans for further growth and maintenance of stable production volumes are linked until 2024. Another largest offshore field in Azerbaijan is the Shah Deniz gas condensate field, whose reserves amount to 1,2 trillion. $\mathrm{m}^{3}$ of gas and 240 million tons of condensate. The development of the ACG and Shah Deniz fields is carried out by international consortia, whose members are the world's largest oil companies (BP, ExxonMobil, Chevron, Total, LUKOIL).

Onshore, within the framework of the PSA, the development of the Kursangi-Karabagly, Mishovdag-Kelammedin, Padar-Kharrami, South-West Gobustan, Binagady, Garachukhur, Govsany-Zikh, Pirsaat, Surakhany, and Kyurovdag fields is underway.

As for the promising projects on the shelf of the Caspian Sea, these are the Inam, Yalama, Araz-Alov-Sharg, Serdar / Kapaz fields. However, the Araz-Alov-Sharg project is frozen until the issue of the status of the Caspian Sea between Azerbaijan and Iran is resolved, and Serdar / Kapaz is between Azerbaijan and Turkmenistan. [7]

Azerbaijan is also actively developing offshore fields within its sector of the Caspian Sea. At the same time, the place and role of Azerbaijan in the energy map of the region is determined not only by the availability of hydrocarbon resources, but also by the country's unique transit possibilities, which allow transporting resources from Turkmenistan and Kazakhstan.

The leadership in the energy sector in Central Asia belongs to Kazakhstan, given its highest rates of both oil production and the level of energy production in the country. The annual production of this strange oil over the past 5 years has reached the level of 80 million tons from the largest developed oil field Tengiz, as well as the Karachaganak field.

A large resource potential, a balanced and flexible policy of the republic's leadership, a number of liberal reforms in the mid-1990s allowed Kazakhstan to attract significant volumes of foreign investment in the oil industry. The largest transnational companies came to Kazakhstan, which, within the framework of JVs, PSAs (Production Sharing Agreements) and concessions, engaged in the development of the country's largest oil and gas condensate fields, which required large capital investments and the use of the latest development and production technologies, which allowed Kazakhstan to achieve impressive success in implementation. large energy projects.

Kazakhstan has the largest recoverable oil reserves in the Caspian region - 5 billion tons, including the Caspian shelf, and its production in 2015 - 81,6 million tons - accounted for more than 54\% of the oil produced in the region (including Azerbaijan, Turkmenistan and Uzbekistan). Kazakhstan's oil exports are the backbone of the national economy and provide an average GDP growth of over 9\% over the past six years. [8]

In recent years, with the growth of incomes of the national economy against the background of an increase in world oil prices, the national sector, having accumulated enough strength, is more and more confidently gaining places from foreign participants in the largest investment projects, which in the foreseeable future will play a decisive role in the industry. In recent years, with the growth of incomes of the national economy against the background of an increase in world oil prices, the national sector, having accumulated enough strength, is more 
and more confidently winning places from foreign participants in the largest investment projects, which in the foreseeable future will play a decisive role in the industry. At the same time, national companies enjoy the full support of the government of the republic. [9]

The total projected recoverable hydrocarbon resources of the Kazakh sector of the Caspian Sea are 8 billion tons or 58 billion barrels.

According to British Petroleum, in terms of proven oil reserves, Kazakhstan (including the Caspian shelf) is in the top ten (9th place) - 5,5 billion tons, which is $2,9 \%$ of the volume of proven oil reserves in the world. In general, in the republic in recent years, a large complex of geological exploration works on the Caspian shelf has been carried out. One of the largest discovered in the world in recent decades is the Kashagan field with recoverable reserves of more than 1,5 billion tons of oil. Fifty companies are involved in oil production in Kazakhstan. Of these, 11 producers are the leaders in oil production with an annual volume of over 1 million tons of oil and gas condensate, which account for $90 \%$ of production.

Most of Iran's deposits were discovered before 1965. At the same time, $70 \%$ of hydrocarbon resources lie on land, and $30 \%$ - on the shelf.

As for the oil and gas industry of Iran, among all the countries of the Caspian "five", its continental shelf is the least studied, which means that its prospects have not been established. OPEC provided data, based on which $13 \%$ of oil reserves and 33,5 trillion cubic meters. $\mathrm{m}$. of natural gas in terms of global reserves constitute Iran's hydrocarbon potential. However, despite this, the country is represented from all the Caspian countries at least in the Caspian Sea. The most promising field in the country is Sardar Dzhangal, which contains 1.4 trillion cubic meters. meters of gas and 10 billion barrels of oil. The company that develops this field is Khazar Exploration and Production Company (KEPCO). It should be noted that Iran uses only one floating platform in the Caspian Sea - Amir Kabir. It is not possible for Iran to develop the subsoil of the Caspian Sea without outside assistance due to many factors. If we talk about the dynamics of production and export of hydrocarbons, then during 2012-14. Experts noted a decrease in levels, which is explained by the imposition of sanctions, but already in 2016 the level of exports and production of hydrocarbons is growing. A feature of the country's oil and gas sector is an urgent need for investments, the introduction of new technological solutions and maintaining the level of renewability of hydrocarbon resources. [10]

Conclusion: Forecasts of oil and gas production and exports remain the driving force behind the development of the energy sector in the countries of the Caspian region and Central Asia. On the basis of these forecasts, national programs for the development of the fuel and energy sector are being developed. Production forecasts are the basis for discussions and advances in future pipeline projects. The new Caspian countries and the states of Central Asia have solved one of the main tasks for themselves - they have attracted funds from foreign oil and gas companies in the energy sector, which acts as a locomotive for economic development. The heads of the new Caspian states paid special attention to the development of oil and gas fields. New pipeline projects have been built or are under discussion, which have secured the countries of the region in the orbit of the interests of the oil and gas business and non-regional states. For more than twenty years of their history, the countries of the Caspian region and Central Asia have created a pipeline architecture that allowed them to export their hydrocarbon resources bypassing the territory of Russia. A significant increase in oil and gas production ensured the filling of new export routes, which became the foundation for the development of the Caspian and Central Asian countries. In the following decades, the countries of the Caspian 
region and Central Asia intends to continue the implementation of ambitious plans to create new export flows aimed at increasing oil and gas supplies to the external market.

\section{REFERENCES}

1. A.K. Magomedov Caspian - Caucasus - Black Sea region: oil routes, trade routes, war routes (history and modern times) / A.K. Magomedov. - Ulyanovsk: UISTU, 2018 .-$250 \mathrm{p}$.

2. Seyed Hamid Hosseini Horami. Caspian resource and Iran's interests in this region // Theories and problems of political research. 2017. Volume 6. No. 4A. S. 101-112.

3. Cohen A. Russia's gas war // The Washington Times. 2009. 13 january.

4. Serebryakov A.O. Oil and gas resources of the Caspian Sea [Electronic resource]. // Geology, Geography and Global Energy, No. 2 (49), 2013. Access mode: URL: http://www.geo.asu.edu.ru/files/2(49)/80-90.pdf

5. Stepanov D.Yu. Problems of cooperation between the countries of the Caspian region in the oil and gas industry: geoeconomic aspect: Avtoref. dis. Cand. econom. Sciences: 08.00.14 // Diplomatic Academy of the Ministry of Foreign Affairs of the Russian Federation - M., 2008.

6. Katona V.K. Oil and Gas of the Caspian Sea: Between Europe and Asia: Workbook 39/2017 /; Russian International Affairs Council (RIAC). - M .: NP RSMD, 2017 .-- 68 p.

7. Ezhiev I. B. Geopolitics of the Caspian region / I. B. Ezhiev. - M.: Andalus, 2007. $204 \mathrm{p}$.

8. Oil and gas resources of Kazakhstan in the system of world and regional relations. Almaty: KISI, 2002, p. 59.

9. Official site of the Ministry of Energy and Mineral Resources of the Republic of Kazakhstan. [Electronic resource]. Access mode: www.memr.gov.kz

10. Seferov A.K., Halova G.O. Cooperation of the Caspian states in the oil and gas sector / In collection. World oil and natural gas markets: increased competition. Ed. S.V. Zhukov - M.: IMEMO RAN ,. 2017 .-- S. 123-131 


\title{
IXRACDA MARKETINQIN ROLUNUN ÖLKə SOVIYYOSINDə QIYMOTLONDIRILMOSI
}

\author{
Fatimə Şirinzadə \\ Dissertant, Azərbaycan Dövlət Aqrar Universiteti, Azərbaycan. \\ Email: fatime.shirinzade.94@mail.ru
}

\section{Резюме}

Известно, что экономика Азербайджана зависит от экспорта нефти и нефтепродуктов. Для устранения этой зависимости и для развития ненефтяного сектора и увеличения экспортного потенциала в стране велась и продолжает вестись большая работа. Опыт зарубежных стран показывает, что маркетинг является одним из важных направлений для увеличения экспорта, так как необходимость экспортного маркетинга, его важность и преимущества объясняются не только на уровне предприятия, но и с точки зрения страны. Одним из важных факторов увеличения экспортного потенциала является правильная организация экспортного моделирования. Экспортный маркетинг - это процесс, с помощью которого компания продает продукт или услугу в зарубежную страну наиболее подходящим и оптимальным способом, а также путем изучения условий жизни, потребностей и стандартов закупок в стране, в которой они будут продаваться. В статье подчеркиваются многие преимущества важности экспортного маркетинга на национальном уровне и оценивается роль маркетинга в формировании имиджа страны.

Ключевые слова: экспорт, маркетинговые функции, маркетинговый план экспорта, потребность, спрос, продукт.

İxracat həm inkişaf etmiş həm də inkişafda olan bütün ölkələr üçün vacibdir. Ancaq məlumdur ki inkişafda olan ölkələrdə ixrac az inkişaf etmişdir. Təbiidir ki, ixrac potensialının artırılmasında vacib faktorlardan biri də ixracın maketinqini düzgün təşkil etməkdir. İxrac marketinqi, bir şirkətin xarici ölkəyə məhsul və ya xidməti ən uyğun və ən optimal yolla həmçinin satış olunacaq ölkənin yaşam, ehtiyac və alıcılıq standartlarını araşdıraraq satmasıdır. Ancaq xarici ölkələrə təqdim olunan məhsullarla, xarici müştərilərə xüsusi olaraq satılan məhsullar arasında fərq var. Bu fərq də 2-ci də məhz marketinqin funksiyalarının istifadə olunmasıdır. Yəni, q1saca ixracda marketinqin istifadəsidir.

Sual yarana bilər ki, bəs niyə ixrac marketinqinə ehtiyac var? Cavabı çox sadədir. Çünki uğurlu satış üçün xarici müştərilərin alış davranışlarını, maraqlarını və ehtiyaclarını bilmək lazımdır. Bütün bu məlumatlar, ixrac marketinq planı vasitəsilə həyata keçirilir. İxrac marketinq planı məhsulu həm mövcud, həm də beynəlxalq alıcılara cəlbedici etmək üçün bir strategiya yaratmaqdır. İxrac marketinq planı ilə müntəzəm marketinq planı arasındakı yeganə fərq məhsulun satış yeridir. İxrac marketinq planını hazırlayan zaman ixrac olunacaq ölkənin təbii şəraiti, sosial-iqtisadi vəziyyəti və rəqib mənzərəsi barədə tam məlumatlı olmaq vacibdir. Həmçinin xarici ölkələrdə əlavə xərclərlə qarşılaşa bilmək ehtimalını da nəzərə almaq lazımdır (əlavə tarif xərcləri, əlavə nəqliyyat xərcləri və s.).

Ümumiyyətlə ixrac marketinqinə olan ehtiyac, onun əhəmiyyəti və üstünlükləri, tək müəssisə səviyyəsində yox, həm də ölkə baxımından da izah edilə bilər. Ölkə səviyyəsində ixrac marketinqinin əhəmiyyəti və üstünlükləri aşağıdakılardır: 
1) Xarici valyuta qazanmaq imkanı - İxrac ölkəyə xarici valyuta gətirir.

2) Beynəlxalq münasibətlərin inkişafi-Siyasi və mədəni mühitin stabilliyi beynəlxalq münasibətlərin tərəqqisindən keçir. Beynəlxalq münasibətlərin inkişaf etdirilməsinin bir yolu da digər ölkələrlə beynəlxalq ticarət əlaqələri qurmaqdır.

3) Ödəniş balansı -Geniş miqyaslı ixracat tədiyə balansı problemini həll edir və ölkələrin əlverişli ödəmə balansına sahib olmasını təmin edir. Ticarət və balans balansındakı kəsir ödəmələr, geniş miqyaslı ixrac yolu ilə silinə bilər.

4) Dünyadakı nüfuz -İxrac sahəsində birinci yeri tutan ölkə, digərlər ölkələrdən hörmət, xoşməramlılıq və şöhrət qazana bilir. Məsələn, Yaponiya ixrac bazarlarında yüksək keyfiyyətli məhsullarına görə beynəlxalq nüfuza sahibdir.

5) Məşğulluq Fürsətləri -İxrac ticarəti daha çox istehsal tələb edir. Daha çox istehsal daha çox məşğulluğun qapılarını açır.

6) İqtisadi inkişafın təşviqi -İqtisadiyyatın və sənayenin inkişafı üçün ixraca çox böyük ehtiyac var. Geniş ixrac sürətli gəlir gətirir və bir millətin iqtisadi inkişafına təkan verir.

7) Yayılma effekti -İxracat sənayesinin inkişafına görə digər sahələr də genişlənir. Məsələn: bankçılıq, nəqliyyat, sığorta və s.

8) Yüksək yaşam standartı -İxrac ticarəti öz növbəsində daha çox istehsal tələb edir və məşğulluq imkanlarını artırır. Daha çox iş, daha çox gəlir, daha çox alıcılıq qabiliyyəti deməkdir, bunun nəticəsində insanlar yeni və daha yaxşı məhsullar istəyir, bu da öz növbəsində həyat səviyyəsini yaxşılaşdırır.

Təbiidir ki, müsbət nüfuza, yüksək texnoloji imicə sahib bir ölkənin məhsulları, bu ölkədə istehsal olunan digər məhsulların ixrac satışlarına da müsbət təsir edə bilər, çünki istehlakçılar müsbət münasibətlərini bu ölkənin digər məhsullarına da köçürürlər. Dövlətin imicinin formalaşmasına ən böyük təsir siyasi sistem, elmi nailiyyətlər, turizm, siyasətçilər, mədəniyyət, idman, məhsul və xidmət ixracı, mədəni dəyərlər, milli firmaların və məhsulların rəqabət qabiliyyəti və ticarət imicidir. Qeyd etdiyim kimi imici formalaşdıran amillərdən biri də məhsul və xidmət ixracıdır ki, bu imic ixrac məhsulları və xidmətlərinin qablaşdırması, dizaynı, satış üslubu, marka şöhrəti və istehsal texnologiyaları ilə əlaqələndirilir.

İstehlakçının bir məhsulla əlaqələndirdiyi bu imic müəyyən bir ölkənin qavrayışında bir stereotip kimi başa düşülür. Beləliklə, bir məhsulun mənşə ölkəsi beynəlxalq ticarətdə qeyrirəsmi də olsa vacib rol oynaya bilir.

Ölkənin müsbət imicini yaratmaq dövlətin vəzifəsidir və dövlət səviyyəsində daha fəal olmaq yalnız ixracatçı müəssisələri dəstəkləmək deyil, həm də ölkə brendini uğurlu marketinq alətlərindən istifadə edərək tanıtmaqdır.

Məsələn, Çin beynəlxalq nəhənglərlə bərabər səviyyədə rəqabət aparmaq və dünya miqyasında istehlakçıların Çin məhsullarına olan etibarını qazanmaq üçün çox çalışmışdır. ÇXR-dən çıxan keyfiyyətsiz məhsullar haqqında stereotip hələ də mövcud olsa da, hazırkı araşdırmalar Çin markalarının istehlakçı qavrayışındakı dəyişiklikləri göstərir.

Azərbaycana gəldikdə isə qeyri-neft məhsullarının ixracında Azərbaycan hələ də dünya ölkələrinin bir çoxundan geri qalmaqdadır. Müqayisə üçün qeyd edim ki 2020-ci ilin yanvariyun aylarında 2019-cu ilin yanvar-iyun ayları ilə müqayisədə qeyri-neft məhsullarından olan təzə tərəvəz ixrac1 4,3 faiz, kartof - 32,0 faiz, meyvə və tərəvəz şirələri - 3,8 faiz, bitki yağları - 1,8 dəfə, çay - 0,5 faiz, marqarin, qida üçün yararlı digər qarışıqlar - 52,1 faiz, polietilen 39,8 faiz, qara metallardan borular - 1,8 dəfə, bentonit gili - 5,2 faiz artmış, təzə meyvə ixracı isə 24,5 faiz, şəkər - 25,9 faiz, tütün - 25,9 faiz, meyvə və tərəvəz konservləri - 0,8 faiz, təbii üzüm şərabları və üzüm suslosu - 52,2 faiz, pambıq lifi - 18,4 faiz, pambıq ipliyi - 22,0 faiz, emal olunmamış alüminium - 5,8 faiz azalmışdır. 
Fikrimcə bu cür azalmaların səbəbi ixrac olunacaq ölkənin ehtiyac və tələbatını, məhsul standartlarını, xidmət standartlarını kifayət qədər araşdırmamaqdır ki, buna da yalnız ixrac marketinqi vasitəsilə nail olmaq olar.

Açar sözlər: ixrac, marketinq funksiyaları, ixrac marketinq planı, ehtiyac, tələbat, məhsul.

\title{
Odəbiyyat
}

1. Маркетинг в схемах, рисунках, таблицах: учебное пособие / П.С. Завьялов. М.: НИЦ ИНФРА-М, 2014. 336 с.

2. Управление маркетингом: учебник для вузов/ перевод с английского; Н. Капон, В. Колчанов, Дж. Макхалберт. Санкт-Петербург : Питер: Лидер, 2010. 832 с.

3. Kohls RL, Uhl IN Marketing of Agricultural Products. - NJ Prentice Hall, http://www.m-economy.ru

4. Shepherd A. W. Approaches to linking producers to markets / A. W. Shepherd // Agricultural Management, Marketing and Finance Occasional Paper. - 2007.

5. Azərbaycan Respublikasının Dövlət Statistika Komitəsinin rəsmi internet səhifəsi. www.stat.gov.az

\section{Assessing the role of marketing in export at the national level}

F.Q.Shirinzade

Azerbaijan State Agricultural University.

\begin{abstract}
It is known that the economy of Azerbaijan depends on the export of oil and oil products, a lot has been done and continues to be done at the national level in order to eliminate this dependence and develop the non-oil sector and increase export potential. The experience of foreign countries shows that marketing takes one of the important place in increasing export. Because the need for export marketing, its importance and advantages are explained not only at the enterprise level, but also at the national level of the country. One of the important factors in increasing the export potential is the proper organization of export marketing. Export marketing is the process by which a company sells a product or service to a foreign country in the most appropriate and optimal way, as well as by examining the living, needs, and purchasing standards of the country in which it will be sold. The article emphasizes the many advantages of the importance of export marketing at the national level, and assesses the role of marketing in formatting the country's image.
\end{abstract}

Keywords: export, marketing functions, export marketing plan, need, demand, product. 


\section{КЛИНИКО-ДИАГНОСТИЧЕСКИЕ ОСОБЕННОСТИ ПОСТМЕНОПАУЗАЛЬНОГО ОСТЕОПОРОЗА У ЖЕНЩИН В УСЛОВИЯХ Г. БАКУ}

\section{Шафаг Асадова, Шарифа Вагабова}

Азербайджанский Медицинский Университет, кафедра акушерства и гинекологии I, Азербайджан. Email: bilal_44@mail.ru

Введение: Изучение состояния здоровья женщин в климактерическом периоде представляет общемедицинскую проблему, т.к. находится на стыке нескольких клинических дисциплин (гинекологии, эндокринологии, невропатологии, травматологии и др.). (Акендрот К. с соавт., 1989; Алтухова А.И., 1965; Лазебник Л.Б., Маличенко Н.Ф., 1999).

Самым серьезным последствием постменопаузы является остеопороз. Остеопороз патологическое разрежение костной ткани без изменения соотношения ее органических и минеральных компонентов, обусловленое физиологическим угасанием функции яичников. Постменопаузальный остеопороз развивается в основном в течение 15-20 лет после менопаузы, приводя к резкому возрастанию переломов в трабекулярных отделах костей (позвонки, лучевая кость, шейка бедра). На профессиональном языке врачей остеопороз называют “скрытой эпидемией”, т.к. в большинстве случаев он протекает без ярко выраженных симптомов, которые могли бы насторожить человека. О наличии у себя постменопаузального остеопороза многие женщины узнают лишь после первого перелома. В связи с этим, остеопороз периода постменопаузы занимает особое место в центре внимания различных авторов, врачей многих специальностей в течение уже более 50 лет (Михайлов Е.Е. с соавт., 1999; Hewenway D. et al., 1988; Velton L.J. et al., 1988).

Материал и методы исследования: Нами была обследована 131 женщина в возрасте 40 - 65 лет. Выделение пациенток с постменопаузальным остеопорозом (основная группа-72 больных) и без остеопороза (контрольная группа- 59 женщин) проводилось на основе данных, полученных при предварительном обследовании с помощью клинического и параклинического методов обследования. Постановка диагноза “остеопороз” проводилась по данным рентгенологического исследования, а также при помощи аппарата для определения изменения костных структур по оптической плотности рентгенограмм. У пациенток с постменопаузальным остеопорозом (основная группа) и женщин в периоде постменопаузы без признаков остеопороза (контрольная группа) определялись в крови уровни гормонов, ферментов и электролитов, способных прямо или косвенно влиять на метаболизм костной ткани, т.е. иметь отношение к развитию постменопаузального остеопороза (эстрадиол; щелочную фосфатазу; кальций). Результаты оценивались при сравнении исследуемых показателей с показателями, характеризующими их нормальный уровень.

Результаты и обсуждения: Основным клиническим проявлением постменопаузального остеопороза является наличие болевого синдрома, проявляюшегося болями в костях и суставах. Наиболее часто болевые расстройства локализуются в костях нижних конечностей и в позвоночнике, с меньшей частотой - в костях верхних конечностей. Наряду с этим, у больных с постменопаузальным остеопорозом выявляются мышечные 
боли, артралгии и артропатии. Они нередко сочетаются с остеохондрозом и варикозным расширением вен, вызывают болевые ощущения в суставах и ограничение их движений. Самые первые проявления артралгии отмечаются в суставах пальцев, при этом возникают жалобы на боль, нарушение подвижности пальцев, уменьшение силы рук. Следующими по локализации артралгий являются коленные и плечевые суставы. При обследовании женщин следует обращать особое внимание и на такие жалобы, как ломкость и выпадение волос, хрупкость и крошение зубов, ногтей, избыточное оволосение (гирсутизм), пигментация и шелушение кожи, уменьшение роста. Эти нарушения отмечаются у значительного числа женщин, обнаруживающих явные признаки остеопороза, что позволило нам отнести их к сопутствующим симптомам остеопороза Указанные расстройства, на наш взгляд, являются клиническим проявлением гипоэстрогенамии и связанных с ней других нарушений гомеостаза. Подтверждением этого является тот факт, что комплексная терапия, направленная на устранение эстрогенного дефицита, восстановление кальций-фосфорного гомеостаза способстовала значительному уменьшению вышеназванной патологической симптоматии. При изучении анамнестических данных установлено, что у женщин с постменопаузальным остеопорозом достоверными фактами повышенного риска развития заболевания являются: наследственная отягощенность переломами у ближайших родственников (мать, сестра и т.п.) $(30,6 \%)$; сидячий характер работы $(79,2 \%)$; умеренно и малоподвижный образ жизни (40,3\%). Это связано с тем, что наследственная патология, дефицит физической активности, опосредованно влияют на прочность костной ткани, вследстие чего кости истончаются и становятся хрупкими.

К другим достоверным признакам риска развития постменопаузального остеопороза, мы отнесли характер питания больных, отличавшийся редким употреблением богатых кальцием молочных продуктов (творог, сыр, катык, молока и др.), избыточным приемом соленой, грубоволокнистой пищи $(76,4 \%)$; значительную подверженность стрессовым нагрузкам (77,8\%), основными причинами которых, были семейная неустроенность, вдовство, одиночество, материальные затруднения, конфликты в семье и т.п Кроме того, к достоверным факторам, подтверждающим эстрогенную недостаточность при постменопаузальном остеопорозе также относятся: а) более ранний возраст менопаузы на момент обследования; б) высокая частота атрофических изменений слизистой влагалища и сенильных кольпитов; в) редкая встречаемость гиперпластических заболеваний половых органов; г) выраженность вегето-сосудистых нарушений, относящихся к симптомам патологического климактерия.

Для объективизации диагноза “остеопороз” больным рекомендуется проводить рентгенологическое исследование трубчатых костей нижних конечностей, а именно, верхней трети бедреной кости. Наши данные показали, что рентгенологический метод является достаточно надежным методом диагностики постменопаузального остеопороза. При изучении полученных рентгенограмм у 58 больных основной группы выявлялись рентгенологические признаки диффузного остеопороза.

Полученные данные свидетельствуют о важной роли эстрогенной недостаточности в патогенезе постменопаузального остеопороза, свидетельством чего является достоверная отрицательная корреляционная связь между проявлениями климактерического синдрома, клиническими признаками остеопороза и концентрацией эстрадиола. Это подтверждается и данным литературы (Gallager J., Nordiu B., 1973), согласно которым преждевременное угасание функции яичников или их удаление в пременопаузе способствует раннему развитию остеопороза. Авторами показано, что 
женщины с удаленными яичниками, на фоне гипоэстрогенемии имеют более низкую массу костной ткани по сравнению со здоровыми женщинами. Возрастная гипоэстрогенемия приводит к снижению активности кальцитонина, вследствие чего активизируется остеокласты и процесс рассасывания костной ткани начинает преобладать над ее восполнением.

Проблемы лечения остеопороза за рубежом изучается давно, особенно активно в последнее десятилетие. Однако до настоящего времени не разработаны общепринятые терапевтические схемы и режимы лечения этого заболевания в городе Баку. Основная цель лечебных мероприятий добиться замедления и прекращения потери костной массы, уменьшить болевой синдром, улучшить функциональное состояние больного, восстановить трудоспособность и психоэмоциональное состояние.

Для повышения эффективности лечения нами был использован принцип этапности, т.к. последовательное применение различных терапевтических методов является наиболее целесообразным и хорошо переносится больными.

На первом этапе лечения проводились терапевтические мероприятия, направленные на регуляцию массы тела, нормализацию психоэмоционального статуса, повышение общего тонуса организма женщин.. Назначалась диета, исключающая сахаросодержащие и кофеиносодержащие газированные напитки (фанта, пепси-кола, кока-кола), варенья, сахар, употребление кофе, алкоголя. Рекомендовалось увеличение в пище содержания продуктов, богатых кальцием, витамином D (рыба, овощи, фрукты, молоко и молочнокислые продукты - сыр, творог, катык).

Для снятия психоэмоционального напряжения рекомендовался прием вегетотропных (беллетаминал, белласпон, беллоид по 0,5-1 таблетки 3 раза в день), успокаивающих средств растительного происхождения (настойки валерианы, пустырника, боярышника по 10-15 капель 3 раза в день). Первый этап лечения проводился, в среднем, в течение 12 месяцев.

Основным методом второго этапа лечения была эстрогензаместительная терапия постменопаузального остеопороза. Применяемые нами эстрогены назначались в низких дозах, которые соответствовали уровню эндогенного эстрадиола в фазе пролиферации у молодых женщин. Для лечения остеопороза мы назначали двухфазный эстрогензаместительный препарат, содержащий эстрадиол-валерат и прогестаген.

Эстрогензаместительная терапия проводилась у 42 женщин основной группы в виде монотерапии препаратом климонорм. В 10 случаях в процессе терапии были выявлены противопоказания к пероральному приему таблеток Климонорма (гастриты, колиты, язвенная болезнь желудка, заболевания печени), вследствие чего больным назначался трансдермальный путь введения эстрогенов при помощи пластыря “Климара", содержащего эстроген-гестагенные препараты. Эстрогенные препараты назначались циклами по 3 недели с недельным перерывом.

При сочетании постменопаузального остеопороза с явлениями сенильного кольпита, атрофией наружных половых органов, нарушением эпителия влагалища больным проводилась сочетанная терапия "Климонормом” с местным назначением влагалищных свечей, содержащих препарат эстриол (“Гинофлор”). При наличии противопоказаний к пероральному применению "Климонорма", преимущество отдавалось местному лечению "Гинофлором".

В процессе лечения в динамике гормональной эстрогензмаместительной терапии, наблюдалось значительное уменьшение остеопоротических проявлений, а также симптомов климактерического синдрома. Оценка состояния больных и эффекта 
проводимой терапии после годичного курса комплексного лечения позволила установить, что у 19 женщин $(26,4 \%)$ полностью нормализовался общий и психоэмоциональный статус, улучшились гормональные и биохимические показатели. Заместительная гормональная терапия Гинофлором у 16 женщин восстанавливала защитный микроэкологический барьер влагалищной стенки, характеризующийся редукцией неприятных ощущений, сухости влагалища, исчезновением зуда, нормализацией сексуальных отношений. При гистологическом исследовании мазка из влагалища отмечено повышение зрелости вагинального эпилетия, нормализация кольпоскопической картины до значений, свойственных здоровым женщинам репродуктивного возраста.

Последующие наблюдения за этими женщинами показало, что состояние их стабилизировалось, но в весеннее и зимнее время они продолжали прием эстрогенов и препаратов, корректирующих электролитный обмен. Непосредственно после отмены медикаментозной терапии эффект лечения оценивался как “значительное улучшение”. В том случае, если через год после завершения терапии не было рецидива заболевания, результат расценивался как "практическое выздоровление".

Улучшение состояния наблюдалось у 40 (55,6\%) женщин основной групп. При опросе больных и обследовании установлено наличие стойкой ремиссии экстрагенитальной патологии, уменьшение проявлений климактерического синдрома, восстановление трудоспособности, тенденция к восстановлению эстрогенного дефицита, нормализации кальций-фосфорного обмена. Эта группа женщин после завершения курсового лечения эстрогенными и негормональными препаратами, спустя 2 месяца вновь начала прием “Климонорма", но доза препарата была снижена до 1 таблетки в день.

Особые трудности представило лечение 11 (15,7\%) женщин основной группы, которые страдали выраженными проявлениями остеопороза и патологического климактерия. На второй неделе после начала лечения "Климонормом" у этих женщин развились побочные явления: чувство тошноты, усиление головной боли, повышение артериального давления, нарушение сна. В связи с этим пероральный прием гормональных препаратов был прекращен. Гормонотерапия проводилась путем трансдермального введения эстрогенов при помощи пластыря "Климара", сочетающихся с назначением негормональных препаратов “Ван-альфа" и “Калтрейд”. В последующие 2 месяца больные отмечали улучшение самочувствия, повышение интереса к жизни, некоторое улучшение настроения, но их, по прежнему, беспокоили чувство тяжести в голове, снижение работоспособности, болевые ощущения в спине, суставах и мышцах. В связи с этим были проведены еще два 3-месячных курса комбинированной терапии с подключением психотропных препаратов (анафранил, гинтон, беллетаминал) и курсов психотерапии. Улучшение состояния наступило у 8 больных к концу первого года лечения, у остальных 3-х женщин изменений в состоянии не наблюдалось.

Третий этап лечения начинался спустя год после начала активного лечения и включал в себя различные реабилитационные мероприятия, включавшие: физиотерапевтию (массаж, гальванический воротник по Щербакову с бромом и новокаином, ультрафиолетовое облучение), лечебную гимнастику, адекватный пищевой режим и избирательное применение гормональных препаратов.

Представленные результаты терапии и профилактики постменопаузального остеопороза у женщин, жительниц г.Баку, свидетельствует о необходимости организации 
специализированных гинекологических кабинетов в женских консультациях, общих поликлиниках, для диспансерного наблюдения за женщинами в климактерическом периоде, что будет способствовать снижению частоты развития постменопаузального остеопороза у женщин в переходном возрасте.

\section{ЛИТЕРАТУРА}

1. Акендрот К., Грассель М., Вессель Г. Диагностика остеопении с использованием рентгенологических и гистоморфометрических методов. Ревматология, 1989, №1, c.51-53.

2. Алтухова А.И. Неврологические синдромы при постклимактерической спондилопатии (вопросы клиники, диагностики и лечения). М., Медицина, 1977, 143 c.

3. Лазебник Л.Б., Маличенко С.Б. Первичный остеопороз: клиника, диагностика и лечение. Лечащий врач, 1999, №7, 13с.

4. Михайлов Е.Е., Беневоленская Л.И., Аникин и др. Частота переломов проксимального отдела бедренной кости и дистального отдела предплечья среди городского населения России. Остеопороз и остеопении, 1999, №3, 11 с.

5. Hewenway D., Coldits G.A., Pillet W.C. et al. Fractures and lifestyle effect of cigarette smoking, alcohol intale, and relative weught on the risk of hip and forearn fractures in middle-aged women. American Journal of Pablic Nealth, 1988, v.78, p.1554-1558.

6. Velton L.J., Kan S.M., Karner N.M., Riggs S.L. Lifetis fracture risk and approach to hip fracture risk asessment based om bone mineral density and age. Journal of Clinical Epidebiology, 1988, v.41. p.985-994. 


\section{EDITORIAL BOARD}

Honorary Editors

Archil Prangishvili

Georgian Technical University. Doctor of Technical Sciences. Full Professor.

Avtandil Silagadze

Correspondent committee-man of National Academy of Georgia. Tbilisi University of International Relationships.

Doctor of Economical Sciences. Full Professor.

Badri Gechbaia

Batumi Shota Rustaveli State University. Head of Business Administration Department. PhD in Economics,

Associate Professor.

Davit Narmania

Tbilisi State University (TSU), Chair of Management and Administration Department. Professor.

Lamara Qoqiauri

Georgian Technical University. Member of Academy of Economical Sciences. Member of New York Academy of Sciences.

Director of first English school named "Nino". Doctor of Economical Sciences. Full Professor.

Lia Eliava

Kutaisi University.Economic expert in the sphere of economy and current events in financial sector.Full Professor.

$\mathrm{PhD}$ in Business Administration.

Liana Ptaschenko

National University «Yuri Kondratyuk Poltava Polytechnic», Doctor of Economical Sciences. Professor.

Nino Didbaridze

Microbiology and Immunology Department. Immunologi Direction. Tbilisi State Medical University. PhD MD.

Paata Koguashvili

Georgian Technical University. Doctor of Economical Sciences. Full Professor. Academician. Member of Georgia Academy of Sciences of Agriculture.

Sergei S. Padalka

Doctor of Historical Sciences, Professor, Senior Researcher at the Department of Contemporary History and Policy at the Institute of History of Ukraine National Academy of Sciences of Ukraine.

Tamar Didbaridze

Tbilisi State Medical University, First University Clinic. PhD in MD.

Zurab Khonelidze

Sokhumi State University. Doctor of Political Sciences. Professor.

Honorary editorial board members:

Agaheydar Seyfulla Isayev

Azerbaijan State Oil Academy. Doctor of Economical Sciences. Professor.

Jacob Meskhia

Tbilisi State University. Faculty of Economics and Business. Full Professor. 


\title{
INTERNATIONAL ADVISORY AND EDITORIAL BOARD
}

\author{
Australia \\ Shahid Khan \\ Monash Business School. Sessional Lecturer. PhD in Management. \\ Vikash Ramiah \\ UNISA School of Commerce. Associate Professor. PhD in Applied Finance.
}

\author{
Azerbaijan \\ Abbas İsmayılov \\ Azerbaijan State Agricultural University. Associate Professor. PhD in Biology Science. \\ Almaz Mehdiyeva \\ Azerbaijan State Oil and Industry University.Associate Professor. PhD in TS \\ Amir $V$. Aliyev \\ Ministry of Health of Azerbaijan Republic Lung Diseases Department. Guba District Central Hospital Head \\ of Department. PhD of Medicine \\ Aytekin Hasanova \\ Azerbaijan Medical University. I Preventive Medicine Faculty. Deputy of Dean. PhD in Medical Biology. \\ Araz Manucheri-Lalen \\ Associated Professor, PhD Department of Psychiatry, Azerbaijan Medical University. \\ Arif M. Mammad-Zada \\ "Geotechnological problems of oil, gas and chemistry", Scientific Research Institute, Professor, Chief Researcher. DS. \\ Azer K. Mustafayev \\ Turan Medical Clinic. Cardiologist. PhD in Medicine. Azerbaijan. \\ Beykas Seyfulla Xidirov \\ Azerbaijan State Oil and Industrial University. Head of department. Doctor of Economical Sciences \\ Djamil Alakbarov \\ A researcher at the Research Institute for Lung Diseases. PhD in medicine. Azerbaijan \\ Elchin Suleymanov \\ Baku Engineering University. Associate Professor of Department Finance. PhD in Economy. \\ Elmira Valiyeva \\ Azerbaijan State Agrarian University Senior teacher of the Chair of Lnguages. \\ Elshan Mahmud Hajizade \\ UNEC. Center of Energy Economics, Director. Doctor of Economic Science. Professor. \\ Emin Mammadzade \\ Institute of Economics of ANAS. Economic institute. Phd in Economy. Associate professor. \\ Farda Imanov \\ ANAS. Georgrapy Institute. Doctor of Georgraphy Sciences. Professor. \\ Garib Mamedov \\ National Academy of Sciences of Azerbaijan Republic. Academician-secretary of the Department of Agrarian \\ Sciences of ANAS, Academician of ANAS. Doctor of Biolgical Sciences. \\ Heyder Guliyev \\ Azerbaijan State Agricultural University. English Teacher. PhD in Philology \\ Ibrahim Gabibov \\ Azerbaijan State Oil and Industrial University. Doctor of Technical Sciences. Professor \\ Jamala Mursalova \\ Azerbaijan National Academy of Sciences. Genetic Resources Institute. PhD BS. \\ Lala Bekirova \\ Azerbaijan State Oil and Industrial University. Azerbaijan National Avation Academy. PhD.TS \\ Leyla I. Djafarova \\ Clinic "Medium" Baku. Doctor of Medical Sciences. Professor \\ Mahmud Hajizade \\ Sector Director of State Fund for Information Technology Development of the Ministry of Communications and High \\ Technologies of the Republic of Azerbaijan, Ministry of Transport, Communications and High Technologies of the \\ Republic of Azerbaijan. \\ Naila Quliyeva \\ Azerbaijan Medical University. Assistant in "Immunology" Program at Paediatrics Diseases Department. Docent and \\ Academic Manager in "Allergology and Immunology" Department. \\ Rafig Gurbanov \\ Azerbaijan State Oil and Industrial University. Doctor of Technical Sciences. Professor \\ Ramiz Gurbanov \\ Azerbaijan State Oil and Industrial University. Doctor of Technical Sciences. Professor \\ Rashad G. Abishov \\ Dental Implant Aesthetic Center Harbor Hospital, Azerbaijan State Doctors Improvement Institute. PhD. Azerbaijan.
}




\section{JULY VOLUME 43 ISSUE 04}

Rena Gurbanova

Azerbaijan State Oil and Industrial University. Associate Professor. PhD in Chemistry.

Saadat Sultanova

Azerbaijan Medical University. II Obstetric Gynecology Department. Doctor of Medical Science. Associate Professor. Sadagat V. Ibrahimova

Azerbaijan State Oil and Industrial University. Academician Doctor of Economical Sciences. PhD

Sain Safarova

Azerbaijan Medical University. $2^{\text {nd }}$ Internal Medicine Department. Associate Professor. PhD in Medicine.

Samira Mammadova

Sumgayit State University. Senior Teacher of History and its teaching methodology in History Faculty. PhD in History.

Sayyara lbadullayeva

Institute of Botany. National Academy of Sciences. Professor. PhD in Biological Sciences.

Sevinj Mahmudova

Azerbaijan State Agrarian University. PhD. Researcher.

Tarbiz Nasrulla Aliyev

Innovation Center of National Academy of Azerbaijan Republic. The deputy of director. Doctor of Economical

Sciences.Professor

Tariel Omarov

Azerbaijan Medical University. Department of surgical diseases. PhD in Medicine

Tofig Ahmadov

Azerbaijan State Oil and Industrial University. Doctor of Geology and Mineralogy Sciences. Professor

Tofig Yusif Baharov

Azerbaijan State Oil Company.Scientific Research Institute. Head of department. Doctor of Geology and Mineralogy

Sciences

Tofig Samadov

Azerbaijan State Oil and Industrial University. Doctor of Technical Sciences. Professor.

Tubukhanum Gasimzadeh

Azerbaijan National Academy of Sciences. Institute of Dendrology of Azerbaijan NAS. Leading researcher PHD in

Biological Sciences, Associate Professor.

Vusal Ismailov

"Caspian International Hospital". Orthopedics Traumatology Expert. MD. Azerbaijan.

Zakir Aliyev

RAPVHN and MAEP. PhD in Agricultural Sciences, Professor of RAE academician.

Zakir Eminov

ANAS. Giography Institute. Doctor of Georgraphy Sciences. Associate Professor.

\section{Bahrain}

Osama Al Mahdi

University of Bahrain, Bahrain Teachers College. Assistant Professor. PhD, Elementary Education and Teaching

\section{Bangladesh}

Muhammad Mahboob Ali

Daffodil International University. Department of Business Administration. Professor.

\section{Belarus}

Tanua Teterinets

Belarusian State University of Agricultural Technology. Doctor of Economical Sciences. Associate Professor.

Vladimir Yanchuk

Belarus State University. Professor. Academy of Postgraduate Education. PhD in Social Psychology.

\section{Bosna \& Hercegovina}

Igor Jurčić

Head of marketing Business group for VSE/SME. Telecommunication Business and Management.

Ratko Pavlovich

University of East Sarajevo. Faculty of Physical Education and Sport. Full Professor. PhD in Sport Sciences.

\section{Brazil}

Paulo Cesar Chagas Rodrigues

Federal Institute of Education, Science and Technology of Sao Paulo. Professor. PhD in Mechanical Engineering. 
Bulgaria

Desislava Stoilova

South-West University "Neofit Rilski". Vice Dean of Faculty of Economics. Associate Professor. PhD in Finance.

Eva Tsvetanova

Tsenov Academy of Economics, Svishtov, Bulgaria Department of Strategic Planning. Head assistant professor. PhD in

Economy.

Jean-François Rouge

University of technology Sofia.Professor researcher. PhD in Management.

Jean-François Rougè

University of Technology, Sofia. PhD in Business law

Milena Kirova

Sofia University "St. Kliment Ohridski". Professor. PhD in Philology.

\section{Croatia}

Dragan Čišić

University of Rijeka. Faculty of Maritime Studies. Full professor. PhD in Logistics, e-business.

\section{Egypt}

Abdelbadeh Salem

Professor at Faculty of Computer and Information Science, Ain Shams University.

Neyara Radwan

King Abdul-Aziz University. Jeddah. KSA. Business Administration Department. Faculty of Economics and Administration. Assistant Professor. Suez Canal University. Mechanical Department. Faculty of Engineering. Assistant Professor.

\section{France}

Michael Schaefer

L'Ässociation 1901 SEPIKE International, Président at SEPIKE International. PhD of Economical Sciences.

\section{Georgia}

Anzor G. Abralava

Georgian Technical University. Doctor of Economical Sciences. Full Professor

Dali Sologashvili

State University named Akaki Tsereteli. Doctor of Economical Sciences. Full Professor

Dali Osepashvili

Professor of Journalism and Mass Communication TSU (Tbilisi State University), Head MA Program "Media and New

Technology"

Davit Tophuria

Tbilisi State Medical University. Head of International Students Academic Department, Associate Professor. PhD in HNA.

Eka Avaliani

International Black Sea University. Associate Professor. PhD in History.

Eka Darchiashvili

Tbilisi State University named after Sv. Grigol Peradze. Assistant of professor. PhD in BA.

Ekaterine Maghlakelidze

The University of Georgia, Associated professor, Business, Economics and Management School.

Enene Menabde-Jobadze

Georgian Technical University. Academical Doctor of Economics.

Eter Bukhnikashvili

Dental clinic "NGM-Innovation Dental". The doctor-stomatologist. PhD in Medicine.

Evgeni Baratashvili

Georgian Technical University. Head of Economic and Business Department. Doctor of Economical Sciences. Full

Professor

George Jandieri

Georgian Technical University; Chief scientist, Institute of Cybernetics of the Georgian Academy. Full Professor

George Malashkhia

Georgian Technical University. Doctor of Economical Sciences. Full Professor.

Giorgi Kepuladze

Akaki Tsereteli State University, Faculty of Business, Law and Social Sciences, PhD in Economics. Invited teacher.

Gulnara Kiliptari

Tbilisi StateMedical University. Head of ICU department. Associate professor.

lamze Taboridze

Scientific Center of the Humanitarian Educational University, Head, PhD in Medicine. Associate professor. 
Irma Makharashvili

Caucasus International University. Dean of Business Faculty. Doctor of Economical Sciences. Full Professor

Ketevan Goletiani

Batumi Navigation Teaching University. Dean of Logistics Faculty.Batumi Shota Rustaveli State University. Doctor TS

Professor.

Larisa Korghanashvili

Tbilisi State University (TSU) named Ivane Javakhishvili. Full Professor

Larisa Takalandze

Sokhumi State University, Faculty of Economic and Business. Doctor of Economic Sciences.

Lia Davitadze

Batumi Shota Rustaveli State University. Higher Education Teaching Professional. PhD in Educational Sciences.

Lia Matchavariani

Tbilisi State University (TSU) named Ivane Javakhishvili. Full Professor, Faculty of Exact \& Natural Sciences (Geography

Dep.)

Loid Karchava

Doctor of Business Administration, Association Professor at the Caucasus International University, Editor-in-Chief of the international Scientific Journal "Akhali Ekonomisti" (The New Economist)

Maia Kapanadze

Georgian State University named Javaxashvili. Doctor of Economical Sciences. Associate Professor.

Maia Matoshvili

Tbilisi State Medical University. The First University Clinic. Dermato-Venereologist. Assistant Professor. PhD in DAPS.

Mariam Darbaidze

Davit Aghmashenebeli National Defense Academy of Georgia. The Head of Education Division. PhD in Biology.

Mariam Kharaishvili

llia State University. Asistent Professor. PhD MD

Mariam Nanitashvili

Executive Director - Wise Development LTD (Training Centre). Associated Professor at Caucasus University. PhD in

Economics

Nana Shoniya

State University of Kutaisi named Akakhi Tsereteli. Doctor of Economical Sciences. Full professor

Natia Beridze

LEPL National Environmental Agency of Georgia, Invited Expert at International Relations and PR Division. PhD in

Political Science.

Nelli Sichinava

Akaki Tsereteli State Universiry. Associate. Professor. PhD.

Nino Gogokhia

Tbilisi State Medical University. Head of Laboratory the First University Clinic. Professor.

Nino Museridze

GGRC Georgian-German Center for Reproductive Medicine, Owner and Clinical Director. The Doctor of Medicine,

Full Professor.

Nino Pirtskhelani

Associated Professor of Department of Molecular and Medical Genetics of Tbilisi State Medical University.

Omari Omarimu

Tbilisi State University named Iv. Javakhishvili. Doctor of Chemical Sciences Professor

Rati Abuladze

St. Andrew the first-called Georgian University of the Patriarchate of Georgia. Faculty of Economics and Eusiness

Edministration. Manager of the Faculty Quality Assurance Office. PhD in Business Administration.

Rusudan Kutateladze

Georgian Technical University. Doctor of Economical Sciences. Full Professor

Rusudan Sujashvili

New Vision University. School of Medicine. Professor,

Simon Nemsadze

Georgian Technical University. Doctor of Technical Sciences. Full Professor

Tamar Giorgadze

Tbilisi State Medical University. Department of Histology, Cytology and Embryology. Assistant Professor.

Tamila Arnania-Kepuladze

Akaki Tsereteli State University. Department of Economics. PhD in Economic.

Tengiz Museliani

Georgian Technical University. Academic Doctor of Technical Sciences. Associate Professor

Timuri Babunashvili

Georgian Business Academy of Science. Doctor of Economical Sciences. Full Professor.

Vladimer Papava

Tbilisi State Medical University. Assistant-Professor. PhD. MD.

Zaira Gudushauri

Georgian-Azerbaijan University named G.Aliyev. Assosiate Professor. PhD. ES. 


\section{Germany}

Hans-Juergen Zahorka

Assessor jur., Senior Lecturer (EU and International Law, Institutions and Economy), Chief Editor of "European Union Foreign Affairs Journal", LIBERTAS - European Institute, Rangendingen

Alexander Dilger

University of Münster. Professor of Business Economics. PhD in Economy.

\section{Greece}

Margarita Kefalaki

Communication Institute of Greece. PhD in Cultural Communication. President of Institute.

\section{Hungary}

Nicasia Picciano

Central European University. Department of International Relations and European Studies.

\section{India}

Federica Farneti

University of Bologna. Department of Sociology and Business Low. Associate Professor. OhD in Economic \& Management.

Prasanta Kumar Mitra

Sikkim Manipal Institute of Medical Sciences. Deptartment of Medical Biotechnology. PhD in Biochemistry. Samant Shant Priya

Lal Bahadur Shastri Institute of Management, New Delhi, Associate Professor in Philosophy PhD in Marketing.

Sonal Purohit

Jain University, Center for Management Studies, Assistant Professor, PhD in Business Administration, Life Insurance, Privatization.

Varadaraj Aravamudhan

Measi Instittue of Management. Associate Professor. PhD in Management.

\section{Iraq}

Rana Khudhair Abbas Ahmed

Irag, Baghdad, Alrafidain University College. Lecturer, Global Executive Administrator, Academic coordinator. PhD in Scholar (CS).

\section{Iran}

Azadeh Asgari

Asian Economic and Social Society (AESS). Teaching English as a Second Language. PhD

\section{Italy}

Simona Epasto

University of Macerata. Department of Political Science, Communication and International Relations. Tenured Assistant Professor in Economic and Political Geography. PhD in Economic and Political Geography

Donatella M. Viola

London School of Economics and Political Science, London, Assistant Professor in Politics and International Relations at the University of Calabria, Italy. PhD in International Relations.

\section{Jordan}

Ahmad Aljaber

President at Gulf University. German Jordan University, Founder / Chairman of the Board. Ph.D in Computer Science Ahmad Zamil

Middle East University (MEU). Business Administration Dept. Associate Professor. PhD Marketing Ikhlas Ibrahim Altarawneh

Al-Huessien BinTalal University. Business Department. Full Professor in Human Resource Management.

Asmahan Majed Altaher

Arab Academy for Banking and Financial Sciences. Associate Professor. PhD in Management Information System.

Sadeq AlHamouz

Middle East University (MEU). Head Computer Information Systems. PHD. Computer Science.

Safwan Al Salaimeh

Aqaba University. Sofrware Engineering Department. Information Technology Faculty. Professor. PhD. 


\section{Kazakhstan}

Alessandra Clementi

Nazarbayev University School of Medicine. MD, GP. Assistant Professor of Medical Practice and Family Medicine Altinay Pozilova

Sirdarya University. Associated professor. PhD in Pedagogy Science.

Anar Mirazagalieva

Astana Internationl University. Vice-President. PhD in Biology.

Anna Troeglazova

East Kazakhstan State University named Sarsen Amanjolov. PhD

Gulmira Zhurabekova

Marat Ospanov West-Kazakhstan State Medical Academy. Department of Human Anatomy. Associate Professor Guzel Ishkinina

Ust-Kamenogorsk, Russian Economy University G. Plekhanov, Associate Professor, PhD in Economic science.

Marina Bobireva

West Kazakhstan State Medical University named Marat Ospanov. PhD

Niyazbek Kalimov

Kostanay Agricultural Institution. PhD

Nuriya Kharissova

State University of Karaganda. Associate Professor of Biological Science

Nikolay Kurguzov

State University of Pavlodar named S. Toraygirova. PhD. Professor.

Oleg Komarov

Pavlodar State Pedagogical Institute. Professor of Department of Economics, Law and Philosophy. PhD in Sociology, Zhanargul Smailova

Head of the Department of Biochemistry and Chemical Disciplines named after MD, professor S.O. Tapbergenova NAC Medical University of city Semey.

\section{Kosovo}

Donat Rexha

Faculty of Economics and Management at the AAB College. Professor. Lecturer. Local Consultant at the UNICEF.

\section{Libya}

Salaheddin Sharif

University of Benghazi, International Conference on Sports Medicine and Fitness, Libyan Football Federation- Benghazi $\mathrm{PhD}$ in Medicine (MD)

\section{Latvia}

Tatiana Tambovceva

Latvian Council of Science. Riga Technical University. Assoiate Professor at Riga Technical University.

\section{Lithuania}

Agne Simelyte

Vilnius Gediminas Technical University, Associate professor. Phd in Social Sciences (Management)

leva Meidute - Kavaliauskiene

Vilnius Gediminas Technical University. Vice-dean for Scientific Research

Vilma (Kovertaite) Musankoviene

e-Learning Technology Centre. Kaunas University of Technology. PHD

Laura Uturyte

Vilnius Gediminas Technical University (VGTU). Head of Project Manager at PI Gintarine Akademy. PhD in Economy.

Loreta (Gedminaitè) Ulvydiene

Professor of Intercultural Communication and Studies of Translation. Vilnius University. PHD

Zhaneta Simanavichiené

Professor, head of Laboratory Business Innovation University of Mykolas Romeris. Honorary consul of Estonia

\section{Macedonia}

Liza Alili Sulejmani

International Balkan University. Head of Banking and Finance department. Assistant Professor. PhD of Economics. 


\section{Malaysia}

Anwarul Islam

The Millennium University. Department of Business Administration. Associate Professor.

Kamal Uddin

Millennium University, Department of Business Administration. Associate Professor. PhD in Business Administration.

\section{Morocco}

Mohammed Amine Balambo

Ibn Tufail University, Aix-Marseille University. Free lance. Consultant and Trainer. PhD in Philosophy. Management Sciences, Specialty Strategy and Logistics.

\section{Nigeria}

Bhola Khan

Yobe State University, Damaturu. Senior Lecturer and Head, Dept. of Economics. PhD in Economics.

\section{Norway}

Svitlana Holovchuk

$\mathrm{PhD}$ in general pedagogics and history of pedagogics.

\section{Pakistan}

Nawaz Ahmad

The Aga Khan University. Chief Examiner. PhD in Management.

\section{Poland}

Grzegorz Michalski

Wroclaw University of Economics. Faculty of Engineering and Economics. PhD in economics. Assistant professor. Kazimierz Waluch

Pawel Wlodkowic University College in Płock, Assistant Professor at the Faculty of Management. PhD in Economy. Robert Pawel Suslo

Wroclaw Medical University, Public Health Department, Health Sciences Faculty, Adjunct Professor of Gerontology Unit. PhD MD.

Tadeusz Trocikowski

European Institute for Eastern Studies. PhD in Management Sciences.

\section{Qatar}

Mohammed Elgammal

Qatar University. Assistant Professor in Finance. PhD in Finance

\section{Romania}

Camelia Florela Voinea

University of Bucharest, Faculty of Political Science, Department of Political Science, International Relations and Security Studies. PhD in Political Sciences.

Minodora Dobreanu

University of Medicine, Pharmacy, Sciences and Technology of Târgu Mureș. Faculty of Medicine. Professor. PhD in Medicine.

Odette (Buzea) Arhip

Ecological University Bucuresti. Professor at Ecological University. PhD.

\section{Russia}

Alexander A. Sazanov

Leningrad State University named A.S. Pushkin. Doctor of Biological Sciences. Professor

Alexander N. Shendalev

State Educational Institution of Higher Education. Omsk State Transport University. Associate Professor

Andrey Latkov

Stolypin Volga Region Institute of Administration, Ranepa. Sc.D. (Economics), Ph.D. (Politics), professor,

Andrei Popov

Director "ProfConsult Group". Nizhniy Novqorod Region. PhD

Anton Mosalyov

Russian State University of Tourism and Service. Associate Professor 
Carol Scott Leonard

Presidential Academy of the National Economy and Public Administration. Vice Rector. PhD, Russian History Catrin Kolesnikova

Samara Architectural and Constructional University. PhD

Ekaterina Kozina

Siberia State Transportation University. PhD

Elena Klemenova

South Federal University of Russia. Doctor of Pedagogical Sciences. Professor

Galina Kolesnikova

Russian Academy of Natural Sciences and International Academy of Natural History. Taganrog Institute of

Management and Economics. Philologist, Psychologist, PhD

Galina Gudimenko

Orel State Institute of Economics and Trade. Department of History, Philosophy, Advertising and Public

Relations.Doctor of Economical Sciences. Professor.

Grigory G. Levkin

Siberian State Automobile and Highway Academy. Omsk State Transport University. PHD of Veterinary Sciences

Gyuzel Ishkinina

Ust-Kamenogorsk affiliation of G. Plekhanov Russian Economy University / Associate Professor, Business, Informatics,

Jurisprudence and General Studies sub-department. PhD in Economic science.

Irina V. Larina

Federal State Educational Institution of Higher Professional Education. Associate Professor

Irina Nekipelova

M.T. Kalashnikov Izhevsk State Technical University. Department of Philosophy. PhD

Larisa Zinovieva

North-Caucasus Federal University. PHD.Pedagogical Science. Associate Professor

Liudmila Denisova

Department Director at Russian State Geological Prospecting University. Associate Professor

Lyalya Jusupowa

Bashkir State Pedagogical University named M.Akmully. PHD Pedagogy Science. Associate Professor

Marina Sirik

Kuban State University. Head of the Department of Criminal Law, Process and Criminalistics of the State Pedagogical

University.

PhD in Legal Sciences.

Marina Volkova

Research Institute of Pedagogy and Psychology. Doctor of Pedagogical Sciences. Professor

Natalia Litneva

Orlov State Institute of Economy and Trade. Volga Branch of The Federal State Budget Educational Institution of Higher Professional Education

Nikolay N. Efremov

Institute of Humanitarian Research and the Russian Academy of Sciences. Doctor of Philology. Research Associate

Nikolay N. Sentyabrev

Volgograd State Academy of Physical Culture. Doctor of Biological Sciences. Professor. Academician.

Olga Ovsyanik

Plekhanov Russian Economic University, Moscow State Regional University. Doctor in Social Psychology.

Olga Pavlova

Medical University named Rehabilitation, Doctors and Health, Professor of the Department of Morphology and

Pathology, Doctor of biological sciences, physiology

Sergei N. Fedorchenko

Moscow State Regional University of Political Science and Rights. PhD

Sergei A. Ostroumov

Moscow State University. Doctor of Biological Science. Professor

Svetlana Guzenina

Tambov State University named G.R. Derzhavin. PhD in Sociology

Tatiana Kurbatskaya

Kamsk State Engineering - Economical Academy. PhD

Victor F. Stukach

Omsk State Agrarian University. Doctor of Economical Sciences. Professor

Zhanna Glotova

Baltic Federal University named Immanuel Kant, Ph.D., Associate Professor.

\section{Saudi Arabia}

Ikhlas (Ibrahim) Altarawneh

Ibn Rushd College for Management Sciences. PHD Human Resource Development and Management.

Associate Professor in Business Administration 
Salim A alghamdi

Taif University. Head of Accounting and Finance Dept. PhD Accounting

\section{Serbia}

Aleksandra Buha

University of Belgrade. Department of toxicology "Akademik Danilo Soldatović", Faculty of Pharmacy

Jane Paunkovic

Faculty for Management, Megatrend University. Full Professor. PhD, Medicine

Jelena Purenovic

University of Kragujevac. Faculty of Technical Sciences Cacak. Assistant Professor. PhD in NM systems.

\section{Sultanate of Oman}

Nithya Ramachandran

Ibra College of Technology. Accounting and Finance Faculty, Department of Business Studies. PhD

Rustom Mamlook

Dhofar University, Department of Electrical and Computer Engineering College of Engineering. PhD in Engineering /

Computer Engineering. Professor.

\section{Sweden}

Goran Basic

Lund University. Department of Sociology. PhD in Sociology. Postdoctoral Researcher in Sociology.

\section{Turkey}

Fuad Aliew

Gebze Technical University, Department of Electronics Engineering, Faculty of Engineering,Associate professor, PhD in Automation engineering

Mehmet Inan

Turkish Physical Education Teachers Association. Vice president. PhD in Health Sciences, Physical Education and Sport Sciences

Muzaffer Sancl

University of Health Sciences. Tepecik Research and Teaching Hospital. Clinics of Gynecology and Obtetrics

Department of Gynecologic Oncologic Surgery. Assocciated Proffesor.

Vugar Djafarov

Medical school at the University of Ondokuzmayıs Turkey. PhD. Turkey.

Yigit Kazancioglu

Izmir University of Economics. Associate Professor, PhDin Business Administration.

\section{UK}

Christopher Vasillopulos

Professor of Political Science at Eastern Connecticut State University. PhD in Political Science and Government.

Frances Tsakonas

International Institute for Education Advancement. Ceo \& Founder. PhD in Philosophy.

Georgios Piperopoulos

Northumbria University. Visiting Professor, Faculty of Business and Law Newcastle Business School. PhD Sociology and

Psychology.

Mahmoud Khalifa

Lecturer at Suez Canal University. Visiting Fellow, School of Social and Political Sciences, University of Lincoln UK. PhD in Social and Political Sciences

Mohammed Elgammal

Qatar University. Assistant Professor. PhD in Finance.

Stephan Thomas Roberts

BP Global Project Organisation. El\&T Construction Engineer. Azerbaijan Developments. SD 2 Onshore Terminal.

Electrical engineer.

\section{Ukraine}

Alina Revtie-Uvarova

National Scientific Center. Institute of Soil Structure and Agrochemistry named Sokolovski. Senior Researcher of the Laboratory, performing part-time duties of the head of this laboratory.

Alla Oleksyuk-Nexhames

Lviv University of Medicine. Neurologyst at pedagog, pryvaty refleksoterapy. MD PD.

Anna Kozlovska

Ukrainian Academy of Banking of the National Bank of Ukraine. Associate Professor. PhD in Ecomomic. 
Bogdan Storokha

Poltava State Pedagogical University. PhD

Dmytro Horilyk

Head of the Council, at Pharmaceutical Education \& Research Center. PhD in Medicine.

Galina Kuzmenko

Central Ukrainian National Technical University, Department of Audit and Taxation, Associate Professor.PhD in

Economiy.

Galina Lopushniak

Kyiv National Economic University named after Vadym Hetman. PhD. Doctor of Economic Sciences, Professor.

Hanna Huliaieva

Institute of Microbiology and Virology, NASU, department of phytopatogenic bacteria. The senior research fellow, PhD in Biology.

Hanna Komarnytska

Ivan Franko National University of Lviv, Head of the Department of Economics and Management, Faculty of Finance and Business Management, Ph.D. in Economics, Associate Professor.

Iryna Skrypchenko

Prydniprovsk State Academy of Physical Culture and Sports. Department of Water Sports. Associate Professor. PhD in

Physical Education and Sport.

Katerina Yagelskaya

Donetsk National Technical University. PhD

Larysa Kapranova

State Higher Educational Institution «Priazovskyi State Technical University» Head of the Department of Economic

Theory and Entrepreneurship, Associate Professor, PhD in Economy,

Lesia Baranovskaya

National Technical University of Ukraine "Kyiv Polytechnic Institute", PhD, Associate Professor.

Liliya Roman

Department of Social Sciences and Ukrainian Studies of the Bukovinian State Medical University. Associate professor,

$\mathrm{PhD}$ in Philology,

Liudmyla Fylyporych

Vice-president of Ukrainian Association of Researchers of Religion (UARR), H.S. Skovoroda Institute of Philosophy of NASU. Doctor of philosophical sciences. Professor

Lyudmyla Svistun

Poltava national technical Yuri Kondratyuk University. Department of Finance and Banking. Associated Professor.

Mixail M. Bogdan

Institute of Microbiology and Virology, NASU, department of Plant of viruses. PhD in Agricultural Sciences.

Nataliya Bezrukova

Yuri Kondratyuk National Technical University. Associate Professor, PhD in Economic.

Oleksandr Voznyak

Hospital "Feofaniya". Kyiv. Head of Neureosurgical Centre. Associated Professor

Oleksandra Kononova

Prydniprovska State Academy of Civil Engineering and Architecture (PSACIA), Assoc.professor of Accounting,

Economics and Human Resources Management department. PhD. in Economic Science.

Oleksandr Levchenko

Central Ukrainian National Technical University, Kropyvnyłskyi. Vice-Rector for Scientific Activities. Professor.

Olena Aleksandrova

Borys Grinchenko Kyiv University, Dean of the Faculty of History and Philosophy. Doctor of Philosophical Sciences,

Professor.

Olena Cherniavska

Poltava University of Economics and Trade, Doctor of Economical Sciences. Professor

Olga F. Gold

Odessa National University named I.I. Mechnikov. Odessa pedagogical college. PhD

Olga I. Gonchar

Khmelnytsky National University, Economics of Enterprise and Entrepreneurship, Doctor of Economic Sciences,

Professor.

Roman Dodonov

Head of the Philosophy Department. Borys Grinchenko Kyiv University. Doctor of philosophical sciences. Professor.

Roman Lysyuk

Assistant Professor at Pharmacognosy and Botany Department at Danylo Halytsky Lviv National Medical University.

Stanislav Goloborodko

Doctor of Agricultural Sciences, Senior Researcher. Institute of Agricultural Technologies of Irrigated Agriculture of the

National Academy of Agrarian Sciences of Ukraine

Svetlana Dubova

Kyiv National University of Construction and Architecture. Associate Professor. PhD in TS.

Tetiana Kaminska

Kyiv Cooperative Institute of Business and Law. Rector. Doctor of Science in Economics. 
Valentina Drozd

State Scientific Research Institute of the Ministry of Internal Affairs of Ukraine. Doctor of Law, Associate Professor, Senior Researcher.

Vasyl Klymenko

Central Ukrainian National Technical University. Department of Electrical Systems and Energy Management. Doctor TS.

Professor.

Victoriya Lykova

Zaporizhzhya National University, PhD of History

Victor P. Mironenko

Doctor of Architecture, professor of department "Design of architectural environment", Dean of the Faculty of Architecture of Kharkov National University of Construction and Architecture (KNUCA), member of the Ukrainian Academy of Architecture

Vita Tytarenko

H.S. Skovoroda Institute of Philosopy, National Academy of Sciences. Professor at the Department of Philosophy. Yuliia Mytrokhina

Donetsk National University of Economics and Trade named after Mykhaylo Tugan-Baranovsky., PhD in Marketing and Management. Associate Professor

Yulija M. Popova

Poltava National Technical University named Yuri Kondratyuk. PhD in Ecomomic. Assiciated professor

\section{Crimea}

Lienara Adzhyieva

V.I. Vernadsky Crimean Federal University, Yevpatoriya Institute of Social Sciences (branch). PhD of History. Associate Professor

Oksana Usatenko

V.I. Vernadsky Crimean Federal University. Academy of Humanities and Education (branch). PhD of Psychology.

Associate Professor.

Oleg Shevchenko

V.I. Vernadsky Crimean Federal University, Humanities and Education Science Academy (branch), Associate Professor. PhD in Social Philosophy

Tatiana Scriabina

V.I. Vernadsky Crimean Federal University, Yevpatoriya Institute of Social Sciences (filial branch). PhD of Pedagogy.

Associate Professor

\section{United Arab Emirates}

Ashok Dubey

Emirates Institute for Banking \& Financial Studies, senior faculty. Chairperson of Academic Research Committee of EIBFS.

PhD in Economics

Maryam Johari Shirazi

Faculty of Management and HRM. PhD in HRM. OIMC group CEO.

\section{USA}

Ahmet S. Yayla

Adjunct Professor, George Mason University, the Department of Criminology, Law and Society \& Deputy Director, International Center for the Study of Violent Extremism (ICSVE), PhD in Criminal Justice and Information Science Carol Scott Leonard

Presidential Academy of the National Economy and Pubic Administration. National Research University - Higher School of Economics. Russian Federation

Christine Sixta Rinehart

Academic Affairs at University of South Carolina Palmetto College. Assistant Professor of Political Science. Ph.D.

Political Science

Cynthia Buckley

Professor of Sociology at University of Illinois. Urbana-Champaign. Sociological Research

Medani P. Bhandari

Akamai University. Associate professor. Ph.D. in Sociology.

Mikhail Z. Vaynshteyn

Lecturing in informal associations and the publication of scientific articles on the Internet. Participation in research seminars in the "SLU University" and "Washington University", Saint Louis

Nicolai Panikov

Lecturer at Tufts University. Harvard School of Public Health. PhD/DSci, Microbiology

Rose Berkun

State University of New York at Buffalo. Assistant Professor of Anesthesiology, PhD. MD 
Tahir Kibriya

Director technical / senior engineering manager. Black \& Veatch Corporation, Overland Park. PhD Civil Engineering. Yahya Kamalipour

Dept. of Journalism and Mass Communication North Carolina A\&T State University Greensboro, North Ca. Professor and Chair Department of Journalism and Mass Communication North Carolina A\&T State University. PhD

Wael Al-Husami

Lahey Hospital \& Medical Center, Nardone Medical Associate, Alkhaldi Hospital, Medical Doctor, International Health, MD, FACC, FACP

\section{Uruguay}

Gerardo Prieto Blanco

Universidad de la República. Economist, Associate Professor. Montevideo.

\section{Uzbekistan}

Guzel Kutlieva

Institute of Microbiology. Senior Researcher. PhD in BS.

Khurshida Narbaeva

Institute of Microbiology, Academy of Sciences Republic of Uzbekistan, Doctor of biological sciences.

Shaklo Miralimova

Academy of Science. Institute of Microbiology. Doctor of Biology Sciences. PhD in BS.

Shukhrat Yovkochev

Tashkent State Institute of Oriental Stadies. Full professor. PhD in political sciences. 
NGO International Center for Research, Education \& Training (Estonia, Tallinn) is publishing scientific papers of scientists on Website and in Referred Journals with subjects which are mentioned below:

\section{(c) The Baltic Scientific Journals}

ISSN: 2613-5817; E-ISSN: 2613-5825; UDC: 0 (0.034);

DOI PREFIX: 10.36962/PIRETC

Proceeding of The International Research Education \& Training Center.

https://scia.website/index.php/piretc

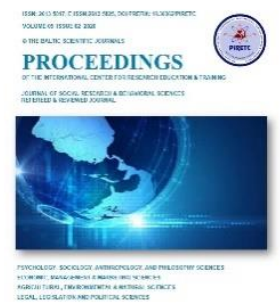

ISSN: 2674-4562, E-ISSN: 2674-4597, UDC: 620.9 (051) (0.034);

DOI PREFIX: 10.36962/ENECO

Proceedings of Energy Economic Research Center. ENECO

https://scia.website/index.php/eneco

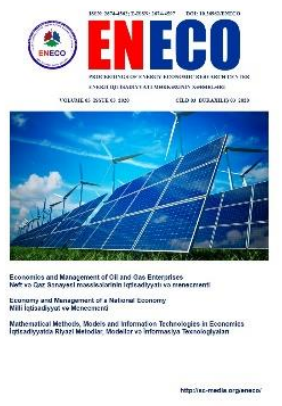

ISSN: 1609-1620, E-ISSN: 2674-5224; UDC: 62 (051) (0.034);

DOI PREFIX: 10.36962/PAHTEI

Proceedings of Azerbaijan High Technical Educational Institutions. PAHTEI https://scia.website/index.php/pahtei

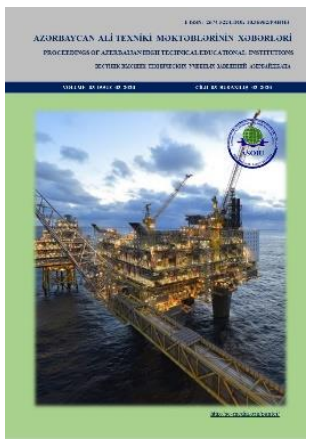


ISSN: 2663-8770, E-ISSN: 2733-2055; UDC:

DOI PREFIX: $10.36962 / E T M$

ETM Equipment, Technologies, Materials

https://scia.website/index.php/etm

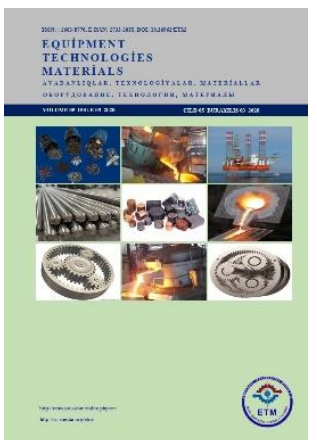

ISSN: 2733-2713; E-ISSN: 2733-2721; UDC:

DOI PREFIX: 10.36962/SWD

SOCIO WORLD-SOCIAL RESEARCH \& BEHAVIORAL SCIENCES

https://scia.website/index.php/swd

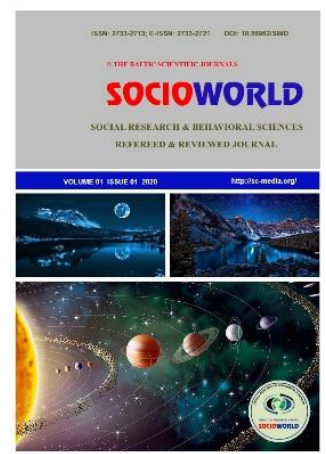

Society of Azerbaijanis living in Georgia. NGO. (Georgia, Tbilisi) is publishing scientific papers of scientists on Website and in Referred Journals with subjects which are mentioned below:

(C) Southern Caucasus Scientific Journals

ISSN: 2346-8068; E-ISSN: 2346-8181;

DOI PREFIX: 10.36962/ALISJMSC

Ambiance in Life-International Scientific Journal in Medicine of Southern Caucasus. https://scia.website/index.php/AILISJMSC

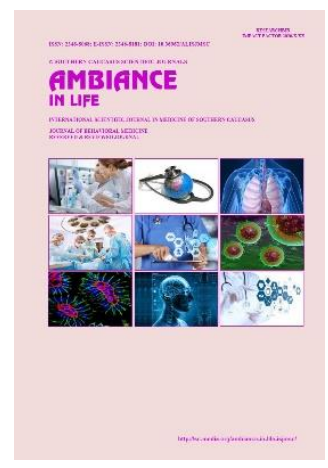


Representation of the International Diaspora Center of Azerbaijan in Georgia. NGO. (Georgia Tbilisi) is publishing scientific papers of scientists on Website and in Referred Journals with subjects which are mentioned below:

\section{(c) Southern Caucasus Scientific Journals}

ISSN: 2298-0946, E-ISSN: 1987-6114; UDC: 3/K-144

DOI PREFIX: 10.36962/CESAJSC

The Caucasus-Economic and Social Analysis Journal of Southern Caucasus

https://scia.website/index.php/CESAJSC

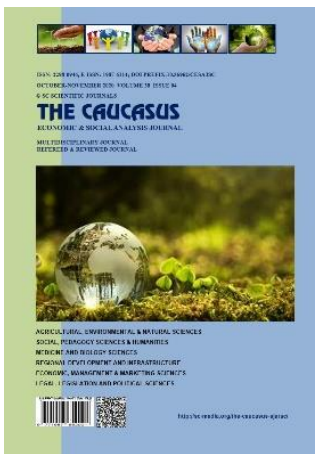



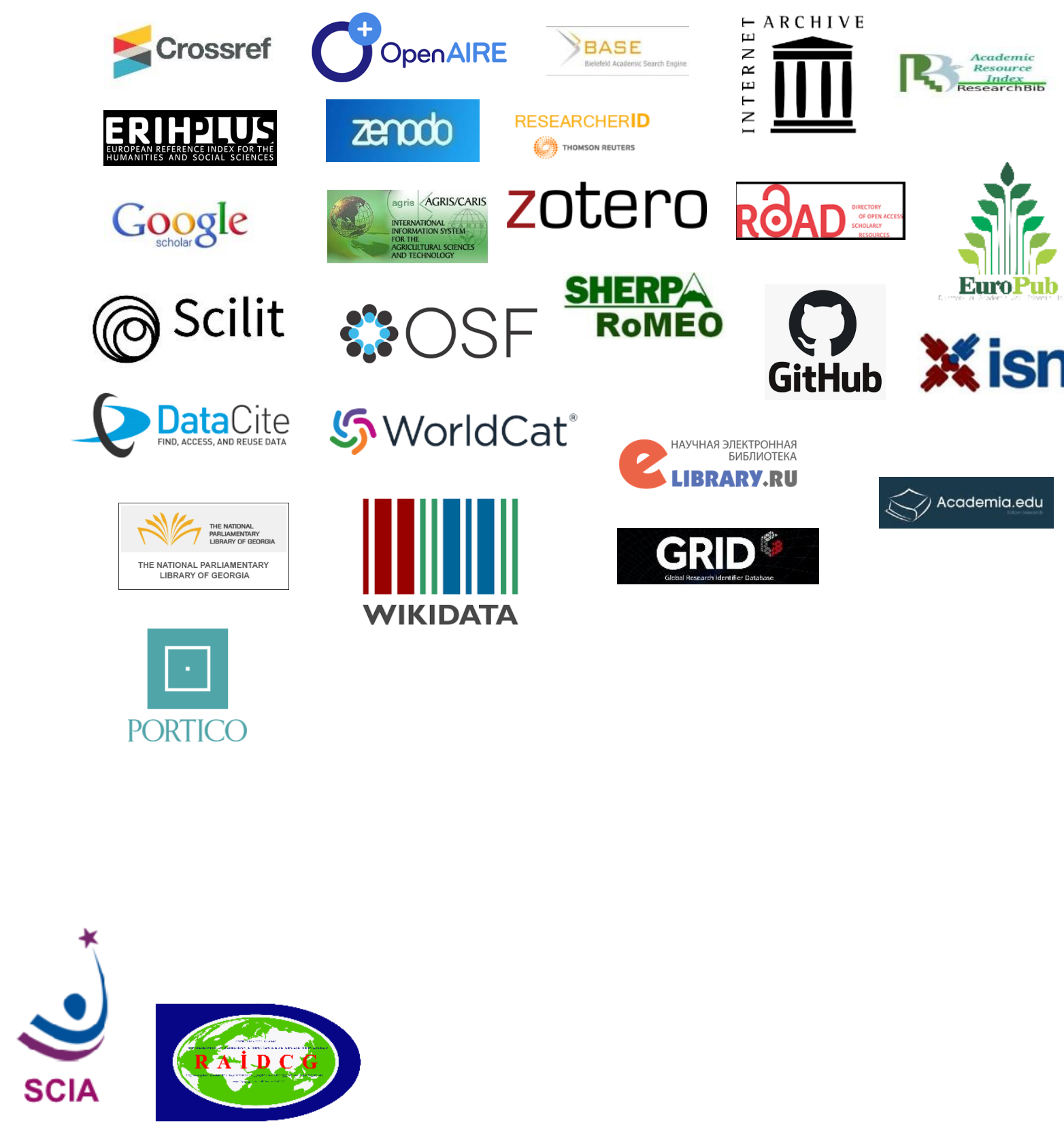

ISSN: 2298-0946; E-ISSN:1987-6114; DOI prefix: 10.36962/CESAJSC

OPublisher: LTD The Southern Caucasus International Academy of Modern Sciences. (UK, London). Director \& shareholder : Namig Isazade. Azerbaijan.

(CEditorial office: 71-75 Shelton Street, Covent Garden, London, WC2H 9JQ, UK.

@Typography: LTD The Southern Caucasus International Academy of Modern Sciences. (UK, London). Registered address: 71-75 Shelton Street, Covent Garden, London, WC2H 9JQ, UK.

Telephones: +994 552417 012; +994518648 894

Website: http://www.scia.education/; https://scia.website/

E-mail: sc.mediagroup2017@gmail.com; publishing@scia-science.org

CPublisher: Representation of Azerbaijan International Diaspora Center in Georgia. SCS Journals (CEditorial office: 0165 Georgia. Marneuli municipality. Village Takalo.

CTypography: Representation of Azerbaijan International Diaspora Center in Georgia. SCS Journals.

Registered address: 0165 Georgia. Marneuli municipality. Village Takalo.

Telephones: +994552 417 012; +994 518648894.

Website: http://www.scia.education/; https://scia.website/

E-mail: sc.mediagroup2017@gmail.com; publishing@scia-science.org 


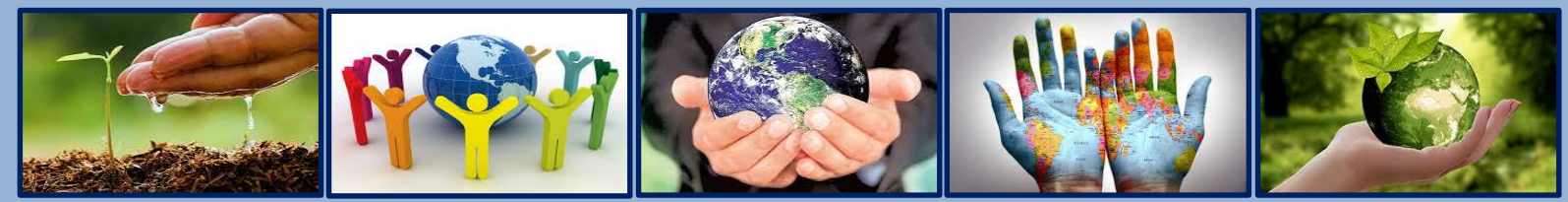

ISSN: 2298-0946, E-ISSN: 1987-6114; DOI PREFIX:10.36962/CESAJSC

JULY 2021 VOLUME 43 ISSUE 04

(C) SC SCIENTIFIC JOURNALS

\section{THE CAUCASUS}

ECONOMIC \& SOCIAL ANALYSIS JOURNAL OF SOUTHERN CAUCASUS

MULTIDISCIPLINARY JOURNAL

REFEREED \& REVIEWED JOURNAL

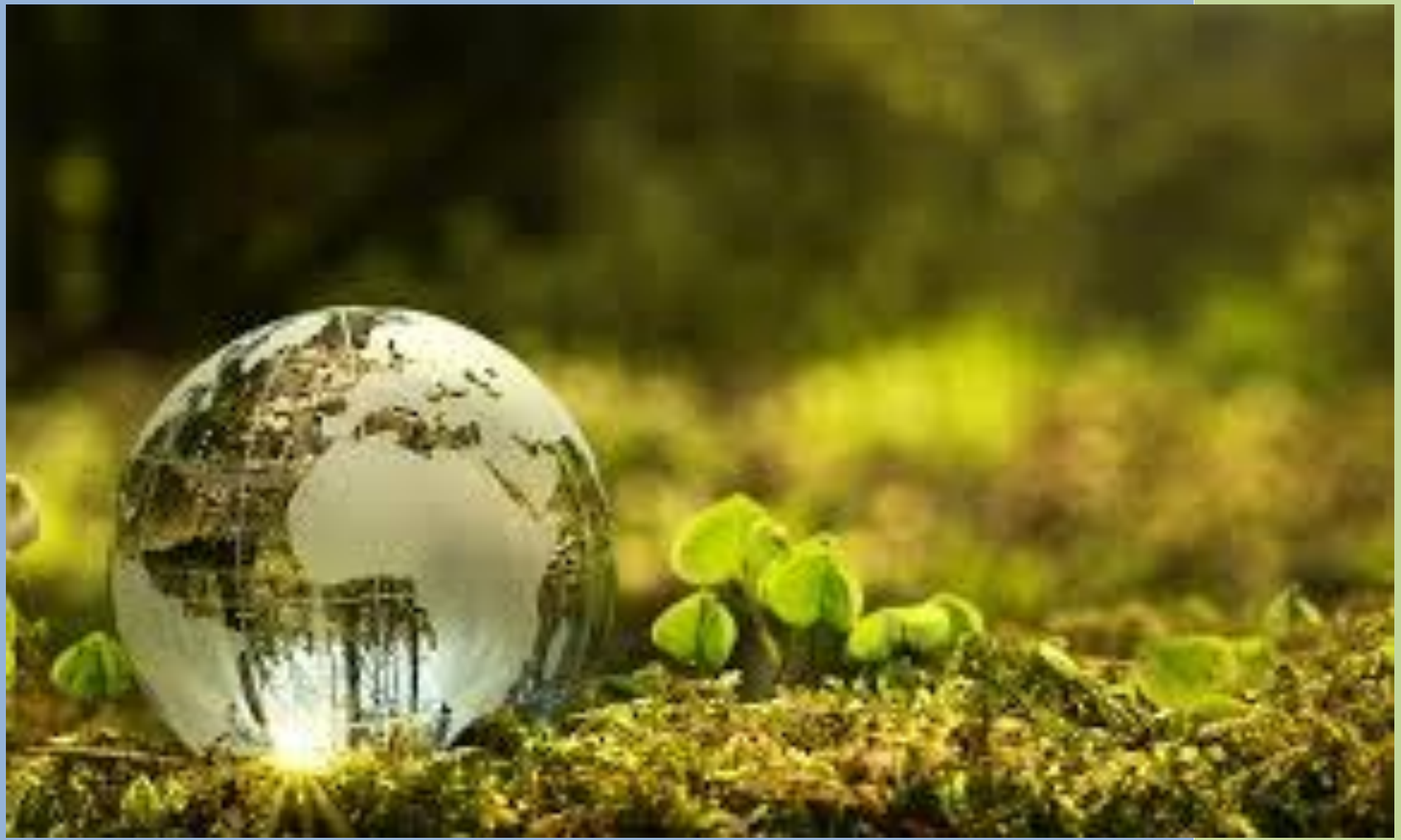

AGRICULTURAL, ENVIRONMENTAL \& NATURAL SCIENCES

SOCIAL, PEDAGOGY SCIENCES \& HUMANITIES

MEDICINE AND BIOLOGY SCIENCES

REGIONAL DEVELOPMENT AND INFRASTRUCTURE

ECONOMIC, MANAGEMENT \& MARKETING SCIENCES

Platform \& workflow by

OJS/PKP

LEGAL, LEGISLATION AND POLITICAL SCIENCES

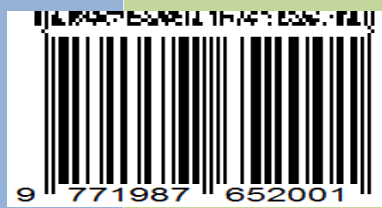

